New insights into distinct eco-epidemiological scenarios of canine visceral leishmaniasis in São Paulo state, Brazil: from diagnosis to parasite-host interaction

Thesis presented to the Graduate Program in Experimental and Comparative Pathology of the School of Veterinary and Animal Sciences of Veterinary Medicine and Animal Sciences of the University of São Paulo to obtain a PhD in Sciences

\title{
Department:
}

Pathology

\section{Concentration Area:}

Experimental and Comparative Pathology

Advisor:

Prof. Dr. Bruno Cogliati

Approved by:

Advisor

São Paulo

2019 
Total or partial reproduction of this work is permitted for academic purposes with the proper attribution of authorship and ownership of the rights.

\section{DADOS INTERNACIONAIS DE CATALOGAÇÃO NA PUBLICAÇÃO}

(Biblioteca Virginie Buff D'Ápice da Faculdade de Medicina Veterinária e Zootecnia da Universidade de São Paulo)

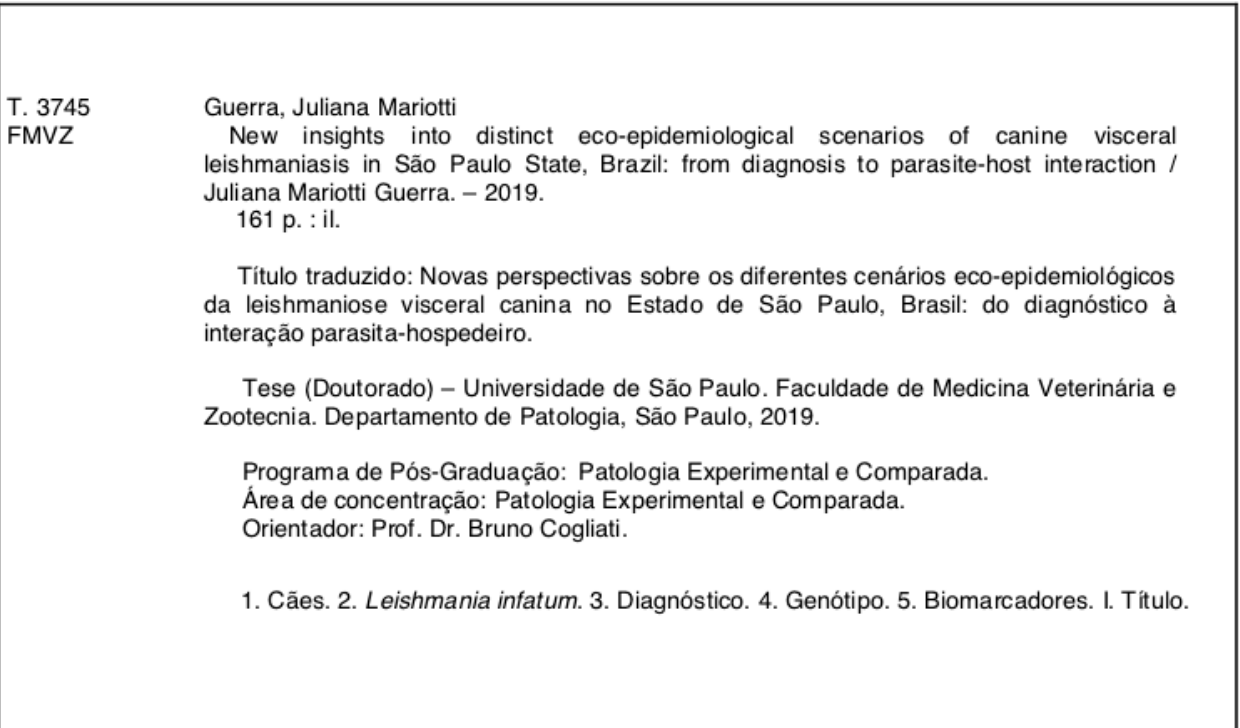

Ficha catalográfica elaborada pela bibliotecária Maria Aparecida Laet, CRB 5673-8, da FMVZ/USP. 


\section{CERTIFICADO}

Certificamos que a proposta intitulada "Novas perspectivas sobre os diferentes cenários eco-epidemiológicos da leishmaniose visceral canina no Estado de São Paulo, Brasil: do diagnóstico à interação parasita-hospedeiro. ", protocolada sob o CEUA n ${ }^{2}$ 4079280115 (ID 001237), sob a responsabilidade de Bruno Cogliati e equipe; Juliana Mariotti Guerra - que envolve a produção, manutenção e/ou utilização de animais pertencentes ao filo Chordata, subfilo Vertebrata (exceto o homem), para fins de pesquisa científica ou ensino - está de acordo com os preceitos da Lei 11.794 de 8 de outubro de 2008, com o Decreto 6.899 de 15 de julho de 2009, bem como com as normas editadas pelo Conselho Nacional de Controle da Experimentação Animal (CONCEA), e foi aprovada pela Comissão de Ética no Uso de Animais da Faculdade de Medicina Veterinária e Zootecnia da Universidade de São Paulo (CEUA/FMVZ) na reunião de 08/04/2015.

We certify that the proposal "New insights into the distinct eco-epidemiologic scenarios of canine visceral leishmaniasis in São Paulo State, Brazil: from diagnosis to parasite-host interaction.", utilizing 150 Dogs (150 males), protocol number CEUA 4079280115 (ID 001237), under the responsibility of Bruno Cogliati and team; Juliana Mariotti Guerra - which involves the production, maintenance and/or use of animals belonging to the phylum Chordata, subphylum Vertebrata (except human beings), for scientific research purposes or teaching - is in accordance with Law 11.794 of October 8, 2008, Decree 6899 of July 15, 2009, as well as with the rules issued by the National Council for Control of Animal Experimentation (CONCEA), and was approved by the Ethic Committee on Animal Use of the School of Veterinary Medicine and Animal Science (University of São Paulo) (CEUA/FMVZ) in the meeting of $04 / 08 / 2015$.

Finalidade da Proposta: Pesquisa

Vigência da Proposta: de 03/2015 a 03/2019 Área: 0

Origem:

\begin{tabular}{lllll} 
Espécie: & Cảes & sexo: Misto & idade: a & N: \\
Linhagem: & N/A & Peso: a & \\
\hline
\end{tabular}

Local do experimento:

São Paulo, 23 de janeiro de 2019

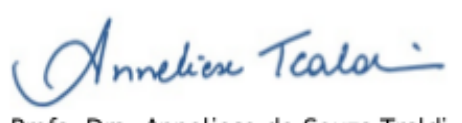

Profa. Dra. Anneliese de Souza Traldi

Presidente da Comissão de Ética no Uso de Animais

Faculdade de Medicina Veterinária e Zootecnia da Universidad de São Paulo

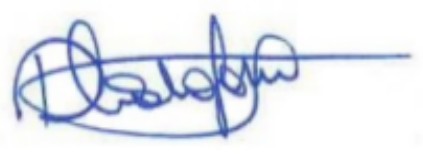

Roseli da Costa Gomes Secretária

Faculdade de Medicina Veterinária e Zootecnia da Universidade de São Paulo 



\section{EVALUATION FORM}

Author: GUERRA, Juliana Mariotti

Title: New insights into distinct eco-epidemiological scenarios of canine visceral leishmaniasis in São Paulo state, Brazil: from diagnosis to parasite-host interaction.

Thesis submitted to the Postgraduate Program in Experimental and Comparative Pathology of the School of Veterinary and Animal Sciences of Veterinary Medicine and Animal Sciences of the University of São Paulo to obtain a $\mathrm{PhD}$ degree in Sciences.

Date:

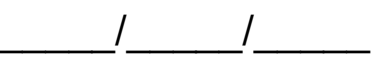

\section{Examination Board}

Prof.Dr.

Institution: Trial:

Prof.Dr.

Institution: Trial:

Prof.Dr.

Institution: Trial:

Prof.Dr. Institution: Trial:

Prof.Dr. Institution: Trial: 



\section{ACKNOWLEDGMENTS}

É um enorme desafio resumir a imensa e profunda gratidão que eu tenho a todos aqueles que, de uma forma direta ou indireta, contribuíram para a realização deste trabalho, e também para minha formação como médica veterinária e pesquisadora cientifica ao longo de tantos anos.

Inicialmente, gostaria de agradecer a toda minha família, especialmente aos meus pais, Eliza e José, e minha vó Olívia pelo amor, carinho, apoio, compreensão sempre. Ao meu namorado e companheiro por tantos anos Bruno Henrique Oliveira por todo amor, força e apoio em todos os momentos. Muito obrigada por sempre me incentivar a seguir meus sonhos e sempre me ajudar a conquistá-los. Obrigada também com o auxílio na revisão do inglês dessa tese.

Também gostaria de agradecer aos meus queridos peludos Brendo (in memorian), Kinder e Bis por todo carinho e felicidade transmitida, e por me incentivarem a seguir nessa profissão que é a medicina veterinária. "Por que é que o cão é tão livre? Porque ele é o mistério vivo que não se indaga." (Clarice Lispector)

Ao meu orientador, Prof. Dr. Bruno Cogliati, muito obrigada, por ter aceitado o desafio e ter me auxiliado. Obrigada pelos ensinamentos, pelas oportunidades, pelo apoio, e, principalmente, por acreditar na minha capacidade.

Gostaria de agradecer ao meu co-orientador Dr. José Eduardo Tolezano, pelo incentivo durante toda essa jornada e pela eterna perseverança, mesmo diante, das adversidades, acreditando na pesquisa e inovação em Saúde Pública.

Aos funcionários, ex-funcionários, bolsistas e aprimorandas(o) do Núcleo de Patologia Quantitativa do Instituto Adolfo Lutz Leonardo Araújo, Juliana Takahashi, Lidia Kimura, Suely Nonogaki, Neuza Shirata, Jéssica Magno, Marília Abrantes, Karolina Fernandes, Maiara Silva, Raquel Monteiro, Daniela Damaceno, Natália Rocha, Estella Becegato, Mayrine Oliveira, Queydson Oliveira, Joana Barrel, Lorenzo Lang e Camila Ferreira, muito obrigada por toda amizade, risadas, paciência, ensinamentos e apoio diário. Obrigada também pela colaboração no processamento das amostras e na realização dos ensaios biomoleculares. Gostaria também de agradecer ao Leonardo Araújo pela ajuda com a revisão do inglês.

Fui muito grata também a colaboração de todos os colegas, funcionários, bolsistas do Centro de Patologia pela cordialidade e ensinamentos, em especial à Natália Fernandes, que realizou as atividades de campo e leitura de lâminas do 
projeto, e ao Rodrigo Réssio e à Cinthya Cirqueira que me apoiaram e me aconselharam com a técnica imuno-histoquímica. Obrigada à Sônia Maria Pereira de Oliveira e à Diretoria Geral do Instituto Adolfo Lutz por possibilitarem e incentivarem meu aprimoramento científico.

Muito obrigada a Estella Becegato, Raquel e Carvalho e Márcio Antônio B. Moreira pela realização dos exames bioquímicos séricos das amostras.

Gostaria de agradecer aos colegas do Instituto Adolfo Lutz, especialmente, aos do Núcleo de Parasitoses sistêmicas do Centro de Parasitologia e Micologia, Gabriela Motoie, Helena Taniguchi, Roberto Hiramoto e Carlos Elias (Tatu), do Núcleo de Biotério do Centro de Procedimentos Interdisciplinares, José Eduardo Barbosa e do Centro de Laboratórios Regionais - Bauru, Virginia Pereira, pela cordialidade, ensinamentos e apoio durante a realização desse projeto, especialmente na coleta e processamento das amostras. Gostaria de agradecer também ao pesquisador André Tempone do Laboratório Novos Fármacos-Doenças Negligenciadas pelo apoio em diferentes aspectos relacionados a leishmaniose visceral.

Obrigada também a Profa. Dra. Elisa Cupolillo e Profa. Dra. Mariana Côrtes Boité do Laboratório de Pesquisa em Leishmaniose do Instituto Oswaldo Cruz pela pronta colaboração ao trabalho através da realização da análise genética dos parasitos, além de toda cordialidade, incentivo e apoio.

A todos os professores do Departamento de Patologia da FMVZ-USP, principalmente, muito obrigada pela contribuição na minha formação profissional na área de patologia animal; e aos queridos amigos, pós-graduandos, aprimorandos, residentes e ex-residentes do Departamento de Patologia da FMVZ-USP, pelos momentos passados juntos.

Muito obrigada aos ex-funcionários, aos ex-alunos e aos alunos atuais do Laboratório de Patologia Morfológica e Molecular - LAPMOL da FMVZ-USP, me lembro do início do laboratório e fico feliz em fazer parte dessa história.

Aos amigos de pós-graduação Angélica, Julieta, Isis, David, Carlos, Danilo, Tereza e Josué, obrigada pelo companheirismo e apoio e às secretárias do Departamento de Patologia Adriana e Milena por todo o auxílio sempre prestado.

Agradeço imensamente à Faculdade de Medicina Veterinária e Zootecnia da Universidade de São Paulo, onde realizei minha formação acadêmica e profissional e pela qual serei sempre grata e orgulhosa. 
À Fundação de Amparo à Pesquisa do Estado de São Paulo - FAPESP (\#12/51267-4), e ao Conselho Nacional de Desenvolvimento Científico e Tecnológico através do projeto de pesquisa em doenças neglicenciadas (MCTI/CNPq/MS-SCTIE-Decit No 40/2012) e ao Projeto Universal No. 14/2011 (Projeto 475459/2011-3), agradeço o apoio financeiro que permitiu a realização desse trabalho.

Muito obrigada a todos os proprietários e profissionais dos serviços de controle de zoonoses/ saúde pública municipais que colaboraram com a realização desse estudo, sendo uma parte fundamental para conclusão da pesquisa.

Um agradecimento especial aos cães, principalmente àqueles que fizeram parte desse projeto de pesquisa, e me mostraram a simplicidade da vida.

Gostaria de agradecer aos membros da Banca Examinadora que gentilmente aceitaram o convite de participar da avaliação desse projeto.

Os meus mais sinceros agradecimentos a todos aqueles que, de alguma maneira, contribuíram para que esse sonho se tornasse possível.

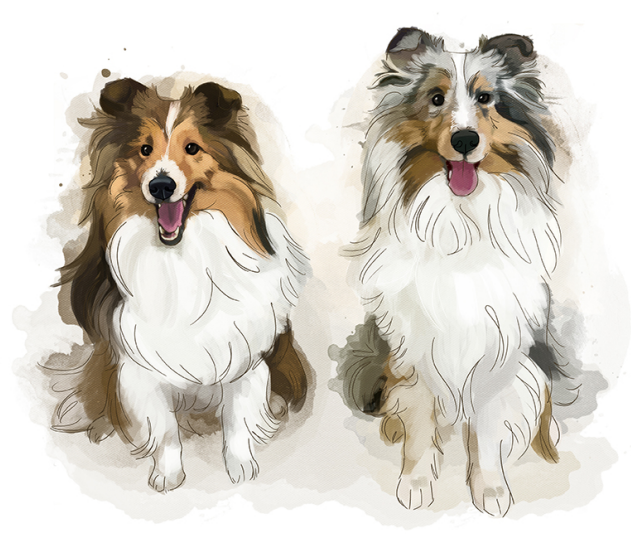


"I am enough of an artist to draw freely upon my imagination. Imagination is more important than knowledge. For knowledge is limited, whereas imagination encircles the world."

- Albert Einstein

As quoted in "What Life Means to Einstein: An Interview by George Sylvester Viereck" in The Saturday Evening Post (26 October 1929). 


\begin{abstract}
GUERRA, J. M. New insights into distinct eco-epidemiological scenarios of canine visceral leishmaniasis in São Paulo state, Brazil: from diagnosis to parasite-host interaction. [Novas perspectivas sobre os diferentes cenários ecoepidemiológicos da leishmaniose visceral canina no estado de São Paulo, Brasil: do diagnóstico à interação parasita-hospedeiro]. 2019. 161 p. Tese (Doutorado em Ciências) - Faculdade de Medicina Veterinária e Zootecnia, Universidade de São Paulo, São Paulo, 2019.
\end{abstract}

Visceral leishmaniasis (VL), caused by the protozoan parasite Leishmania (Leishmania) infantum and transmitted to humans and reservoir hosts by female sandflies, represents a serious public health problem due to its continuous expansion to new areas and urban centers. In São Paulo (SP) state, Brazil, VL has a distinct temporal-geographic pattern dispersion, first appeared in the northwestern (NWSP) region, spreading in a southeastern (SESP) direction over time. The epidemiology and ecology of the disease in a particular region are determined by characteristics of the parasite, vertebrate hosts and invertebrate vectors species. Domestic dogs are widely considered to be the main reservoir of the parasite, that leads to the canine visceral leishmaniasis (CVL), which usually precedes human cases. The objectives of this doctoral thesis were to improve the cytopathological methods for direct diagnosis of CVL and to analyze the pathological and molecular fundamentals of host-parasite interactions from different eco-epidemiological scenarios in SP state, Brazil. In a first instance, we performed cytopathological methods as smear cytology (SC), liquidbased cytology (LBC), cell block (CB) and immunocytochemistry (ICC) in popliteal lymph nodes samples of dogs naturally infected with $L$. infantum to improve the CVL diagnosis. We showed that SC was the most accurate morphological diagnostic method (45.0\%). Besides, LBC reduced the number of unsatisfactory cases (low sampled cell number), allowed excellent cellular preservation and the application of ancillary techniques, such as CB and ICC. CB-ICC alone or associated with SC demonstrated significantly higher sensitivity $(70.00 \%$ and $72.00 \%$, respectively) when compared to the SC alone (34.00\%). CB-ICC showed to be more effective in the detection of infected animals with mild clinical signs and a promising tool to improve diagnosis of CVL and may be applied in routine epidemiological screening. Subsequently, lymph nodes samples of dogs naturally infected with $L$. infantum from NWSP and SESP of SP state were subject to a series of histopathology and 
immunohistochemistry ( $\mathrm{HC})$ analysis to describe microscope lesions, parasite load, and cytokine profile. We evidenced differences between the two eco-epidemiologic scenarios of CVL in SP state. In SESP region, a marked subcapsular inflammatory infiltration and histiocytosis were noted in the popliteal lymph node tissues, while significantly higher parasite burden $(p=0.0004)$ and IHC scores of IL-1 $(p=0.0275)$ and IL-4 (0.0327) were observed in animals from NWSP area. A final study proposed the characterization of the parasite genotype in dogs naturally infected with $L$. infantum from SESP and NWSP areas. The deletion genotype of L. infatum on LinJ.31.2380 locus was predominantly identified in the SESP, with a frequency of $44.44 \%$, while the non-deletion genotype was observed in $35.19 \%$ of the samples $(p=0.01945)$ from the NWSP area. Eight (14.81\%) and three (5.56\%) samples from NWSP demonstrated a third, mixed profile for the deleted site, representing heterozygosity equivalent and non-equivalent, respectively. This study showed no statistical difference among the specific genotype, the clinical status and the parasite load in the popliteal lymph node samples of the dogs. Differences in genetic profile of $L$. infantum population and in the host immune response associated with higher parasite burden in dogs can also contribute to explain the distinct eco-epidemiological patterns of $V L$ in specific geographic regions of SP state, which requires the development of early/accurate diagnosis, better control and surveillance strategies to improve both public and animal health.

Keywords: Dogs. Leishmania infatum. Diagnosis. Genotype. Biomarkers. 


\section{RESUMO}

GUERRA, J. M. Novas perspectivas sobre os diferentes cenários ecoepidemiológicos da leishmaniose visceral canina no estado de São Paulo, Brasil: do diagnóstico à interação parasita-hospedeiro. [New insights into distinct ecoepidemiological scenarios of canine visceral leishmaniasis in São Paulo state, Brazil: from diagnosis to parasite-host interaction.]. 2019. 161 p. Tese (Doutorado em Ciências) - Faculdade de Medicina Veterinária e Zootecnia, Universidade de São Paulo, São Paulo, 2019.

A leishmaniose visceral (LV), causada pelo parasito protozoário Leishmania (Leishmania) infantum e transmitida para humanos e hospedeiros por fêmeas de flebotomíneos, representa um grave problema de saúde pública devido à sua contínua expansão para novas áreas e centros urbanos. No estado de São Paulo (SP), a LV apresenta um padrão de dispersão temporal e geográfica distinta, surgindo inicialmente na região noroeste (NOSP), e espalhando-se no sentido sudeste (SESP) ao longo do tempo. A epidemiologia e ecologia da doença em uma determinada região são determinadas pelas características das espécies parasitos, hospedeiros vertebrados e vetores invertebrados. Cães domésticos são amplamente considerados como o principal reservatório do parasito, que leva à leishmaniose visceral canina (LVC), a qual geralmente precede os casos humanos. Os objetivos desta tese de doutorado foram aprimorar as técnicas citopatológicas para o diagnóstico direto da LVC e analisar os fundamentos patológicos e moleculares das interações parasitohospedeiro advindos de diferentes cenários eco-epidemiológicos no Estado de São Paulo. Em um primeiro momento, realizamos exames citopatológicos como a citológica convencional (CC), a citologia de base líquida ( $\mathrm{CBL}$ ), o emblocado celular (EC) e a imunocitoquímica (ICC) em amostras de linfonodos poplíteos de cães naturalmente infectados com $L$. infantum para o aprimoramento diagnóstico da LVC. Nós demonstramos que $\mathrm{CC}$ foi o método diagnóstico morfológico mais preciso $(45,0 \%)$. Além disso, a CBL reduziu o número de casos insatisfatórios (baixo número de células amostradas), permitiu excelente preservação celular e a aplicação de técnicas complementares, como EB e ICC. O EB-ICC sozinho ou associado ao CC demonstrou sensibilidade significativamente maior $(70,00 \%$ e $72,00 \%$, respectivamente) quando comparado ao CC isolado (34,00\%). O EB-ICC mostrou-se mais eficaz na detecção de animais infectados com sinais clínicos leves e uma 
ferramenta promissora para melhorar o diagnóstico de LVC, podendo ser aplicado na triagem epidemiológica de rotina. Posteriormente, amostras de linfonodos de cães naturalmente infectados com $L$. infantum do NWSP e SESP do Estado de SP foram submetidos a uma série de análises histopatológicas e imuno-histoquímicas (IHQ) para descrever lesões microscópicas, carga parasitária e perfil de citocinas. Evidenciamos diferenças entre os dois cenários eco-epidemiológicos da CVL no Estado de SP. Na região SESP, um acentuado infiltrado inflamatório subcapsular e histiocitose foram notados nos tecidos dos linfonodos poplíteos, enquanto uma carga significativamente maior de parasitos $(p=0,0004)$ e dos escores IHQ de IL-1 $\beta$ ( $p=$ $0,0275)$ e IL-4 $(0,0327)$ foram observados em animais da área do NOSP. Um estudo final propôs a caracterização do genótipo do parasito em cães naturalmente infectados com $L$. infantum das áreas SESP e NOSP. O genótipo com deleção no loco LinJ.31.2380 de $L$. infatum foi predominantemente identificado no SESP, com uma frequência de 44,44\%, enquanto o genótipo de não-deleção foi observado em 35,19\% das amostras $(p=0,01945)$ da área da NOSP. Oito $(14.81 \%)$ e três $(5.56 \%)$ amostras do NOSP demonstraram um terceiro perfil misto para o sítio deletado, representando heterozigosidade equivalente e não equivalente, respectivamente. Este estudo não mostrou diferença estatística entre o genótipo específico, o estado clínico e a carga parasitária nas amostras de linfonodo poplíteo dos cães. Diferenças no perfil genético da população de $L$. infantum e na resposta imune do hospedeiro associada a maior carga parasitária em cães também podem contribuir para explicar os distintos padrões eco-epidemiológicos da LV em regiões geográficas específicas do Estado de São Paulo, o que requer o desenvolvimento precoce diagnóstico preciso, melhor controle e estratégias de vigilância para aprimorar a saúde pública e animal.

Palavras-chave: Cães. Leishmania infatum. Diagnóstico. Genótipo. Biomarcadores. 


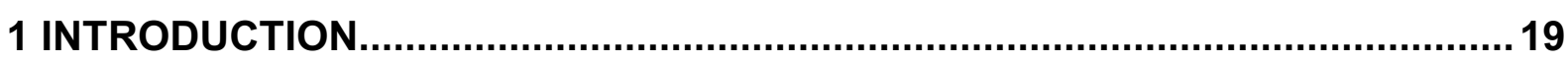

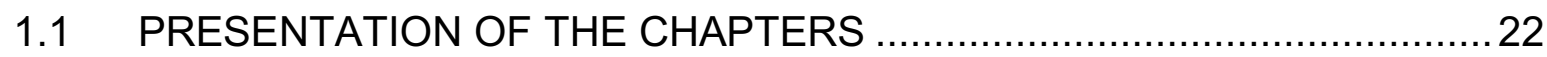

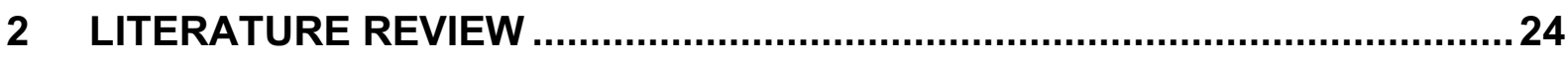

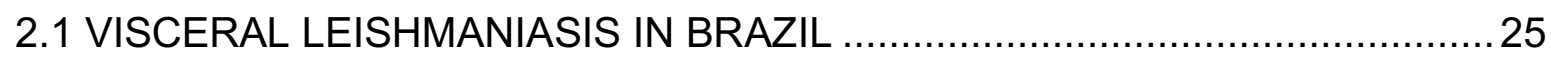

2.2 VISCERAL LEISHMANIASIS IN THE STATE OF SÃO PAULO $\ldots \ldots \ldots \ldots \ldots \ldots . . \ldots \ldots$

2.3 LIFE CYCLE AND TRANSMISSION .................................................. 30

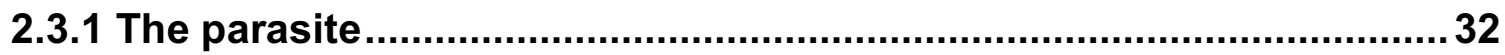

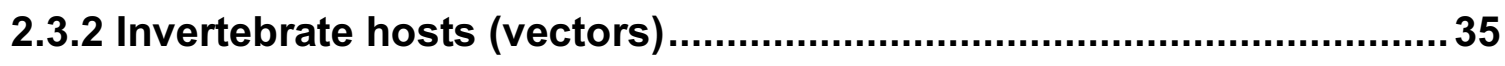

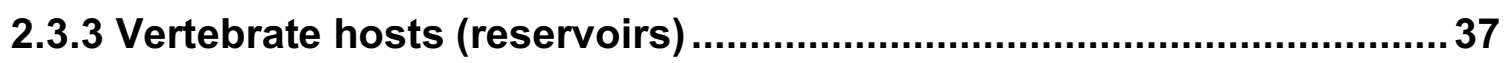

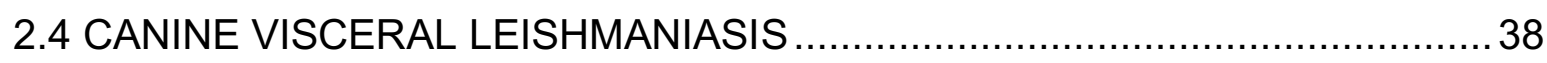

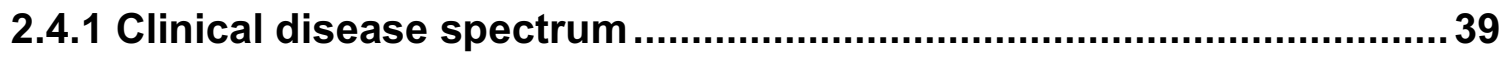

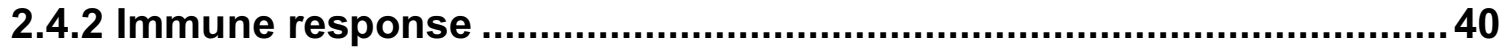

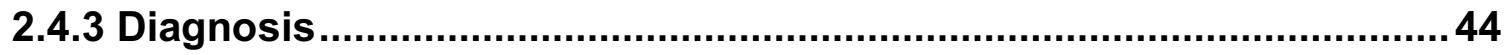

2.4.3.1 History, clinical signs, physical examination and clinical laboratory

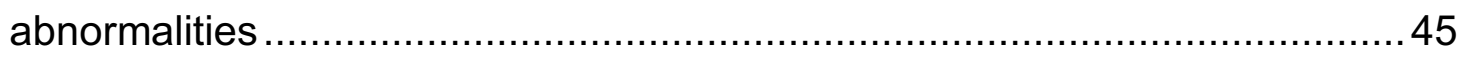

2.4.3.2 Laboratory diagnosis ........................................................ 46

2.4.3.2.1 Parasitological methods............................................... 46

2.4.3.2.2 Serological methods ............................................... 49

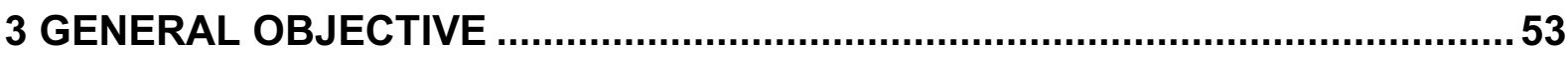

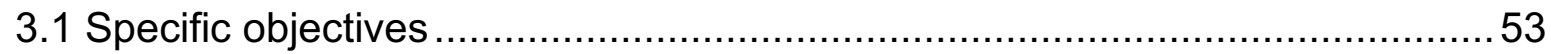

4 Evaluation of cytopathological techniques for the diagnosis of canine visceral leishmaniasis in lymph node samples................................................55

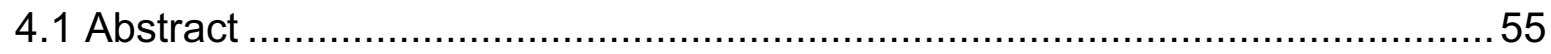

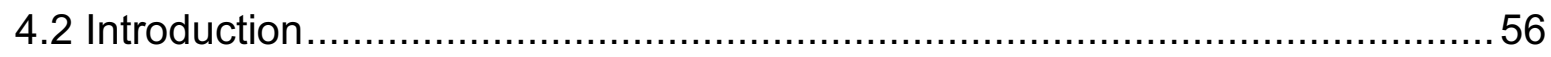

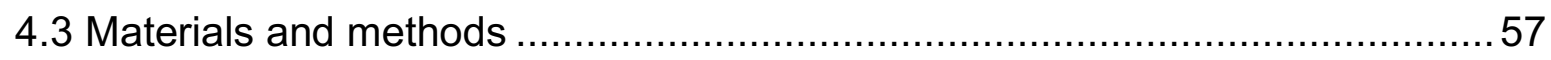

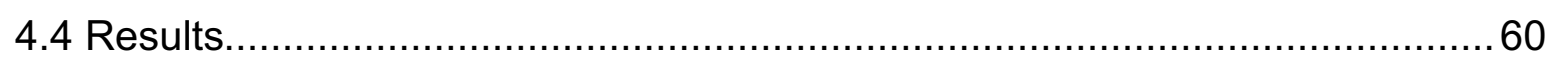

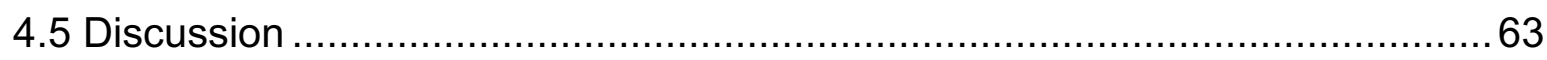

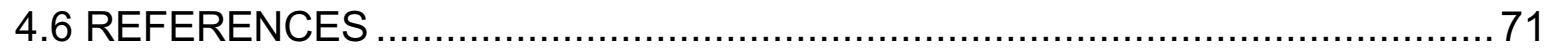


5 Cytokine profile and parasite load in lymph nodes of dogs naturally infected with Leishmania infantum from distinct epidemiological scenarios in Sao Paulo

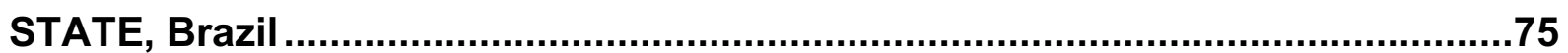

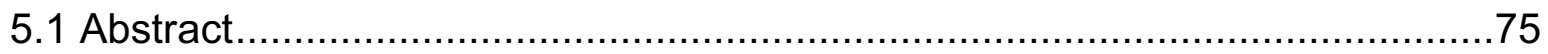

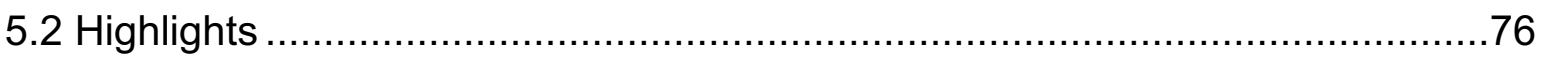

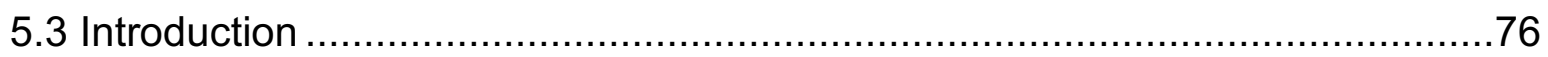

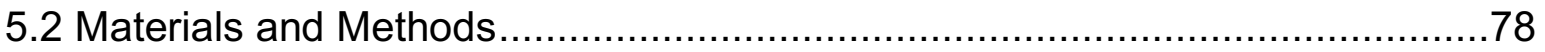

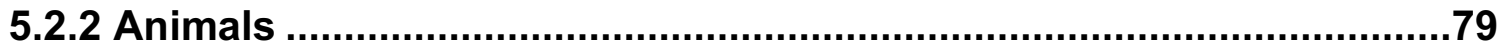

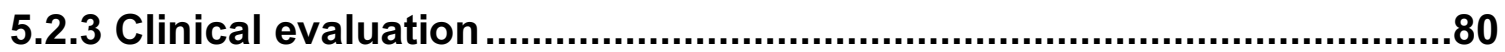

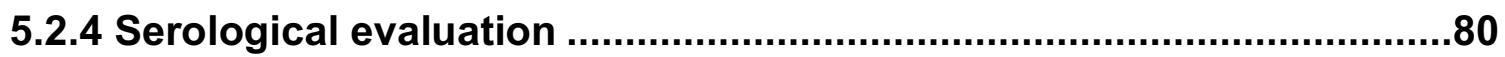

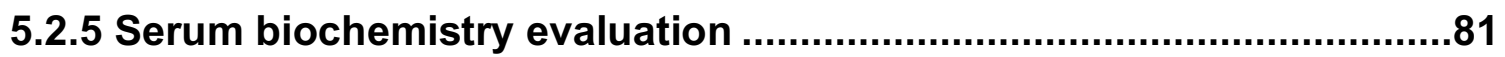

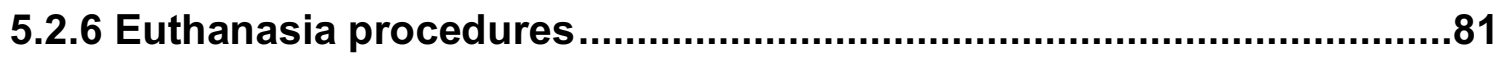

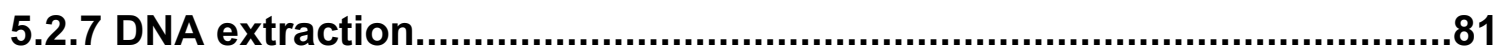

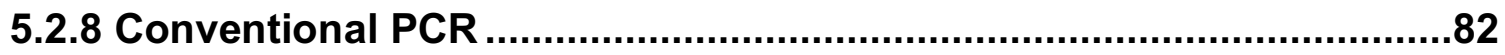

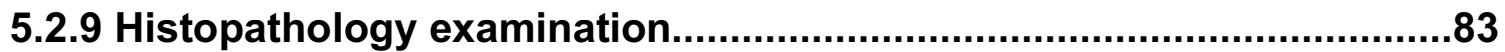

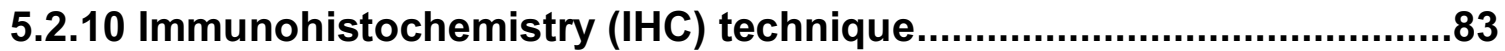

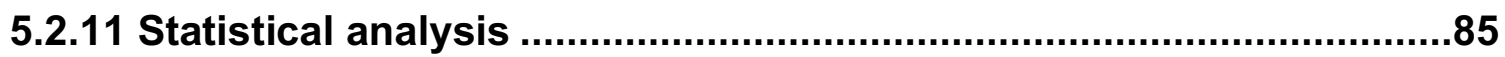

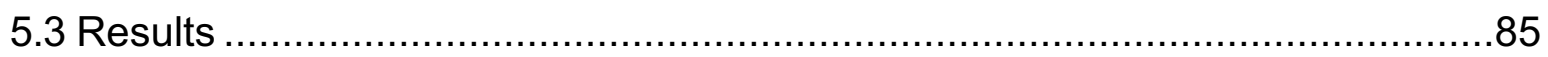

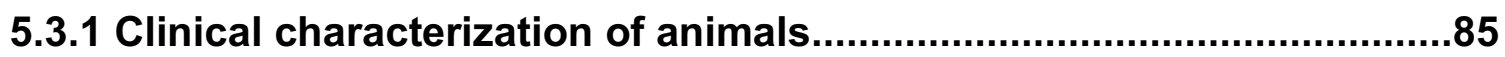

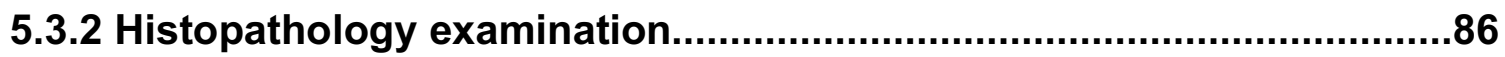

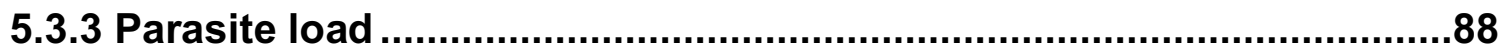

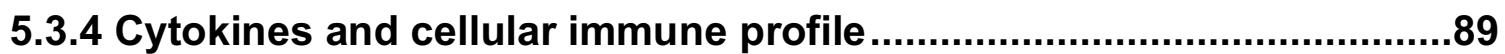

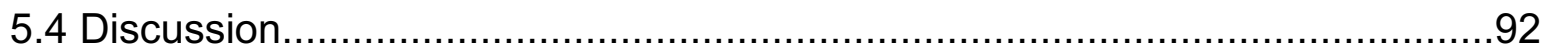

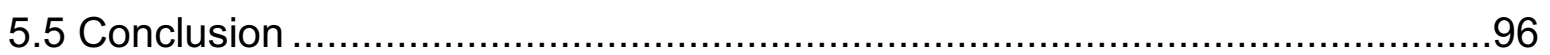

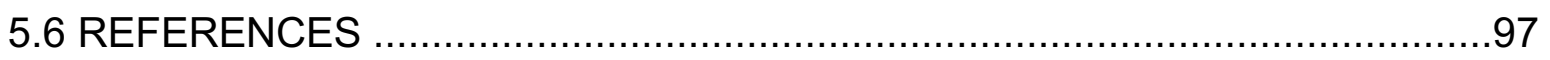

6 EVALUATION OF L. INFATUM GENETIC MARKER ON CHROMOSSOME 31 IN DOGS NATURALLY INFECTED IN SÃO PAULO STATE, BRAZIL.....................111

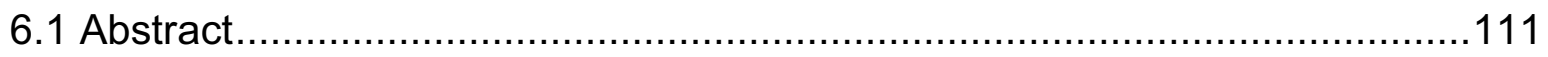

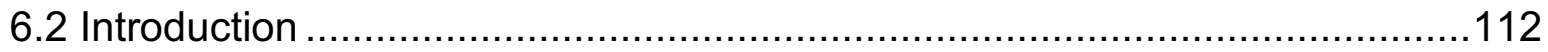

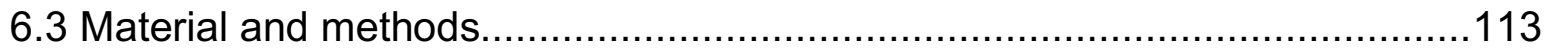

6.3.1 Ethics Statement ........................................................................113

6.3.2 Animals and study design .........................................................114

6.3.3 Clinical evaluation ........................................................................114 
6.3.4 Sample collection and storage ....................................................114

6.3.5 Serological methods......................................................................115

6.3.6 Serum biochemistry evaluation .......................................................115

6.3.8 Conventional PCR......................................................................116

6.3.9 Genetic analysis of the LinJ.31.2380 locus .....................................116

6.3.10 Determination of Parasite burden..................................................117

6.3.11 Statistical analysis .................................................................... 118

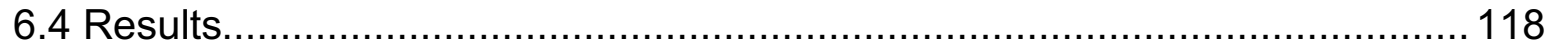

6.4.1 Frequency of the deletion on LinJ.31.2380 locus............................118

6.4.2 Diversity of the mutation on LinJ.31.2380 locus according to geographic regions..................................................................................119

6.4.3 Diversity of the mutation on LinJ.31.2380 locus according to clinical

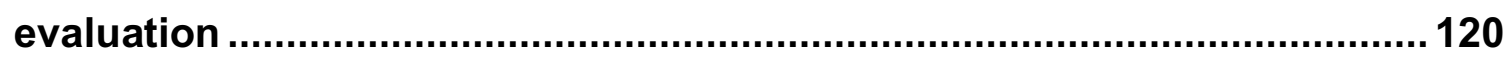

6.4.4 Association of the mutation on LinJ.31.2380 locus and parasite load 120

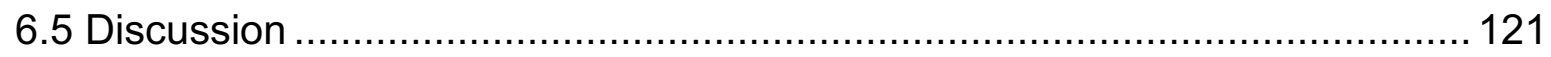

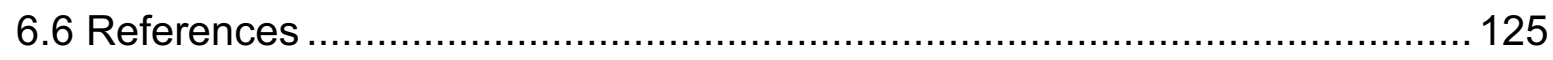

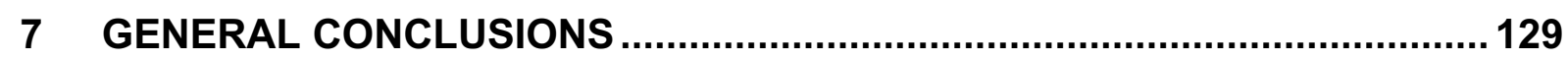

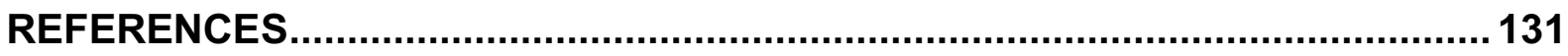





\section{INTRODUCTION}

Leishmaniasis is a vector-borne disease caused by protozoan parasites belonging to the genus Leishmania (order Kinetoplastida, family Trypanosomatidae) (REITHINGER; DUJARDIN, 2007). The main transmission form of the parasite to human and several sylvatic and domestic species is through the bite of blood sucking female phlebotomine sandflies (Diptera, Psychodidae), of the genus Phlebotomus or Lutzomyia (GONTIJO; MELO, 2004).

Leishmaniasis is endemic in nearly 100 countries and 3 territories ranging the Mediterranean Basin, the Middle East, the Indian sub-continent, and the tropical regions from America and Africa (ALVAR et al., 2012; BURZA; CROFT; BOELAERT, 2018). The disease is currently among the six endemic diseases considered as high priorities worldwide and it is still one of the most neglected tropical diseases (HOTEZ et al., 2006; REZVAN; MOAFI, 2015). It is estimated that the prevalence of the different clinical forms of leishmaniasis exceeds 12 million cases in the world and that about 360 million people live in risk areas (ALVAR et al., 2012). Besides, it is becoming more important due to globalization, climate changes and other circumstances which allow the parasite and its vectors to spread (ANTONIOU et al., 2013, LORIA-CERVERA; ANDRADE-NARVÁES, 2014).

Leishmania infection can give rise to a spectrum of diseases depending on the causative Leishmania species, the virulence factors of the parasite, and the immune status of the host (HERWALDT, 1999). In humans, leishmaniasis has three general forms - cutaneous, mucocutaneous and visceral. The cutaneous leishmaniasis comprises cutaneous lesions in varying degrees of severity, that sometimes could be difficult to heal and leave visible scars. The second form is the mucocutaneous leishmaniasis that affects the mucous layers of the nose, mouth, throat and surrounding tissues, many times leading to mutilating lesions (GRIMALDI; TESH, 1993; DESJEUX, 2004). Visceral leishmaniasis (VL), also known as Kala-azar, is the most severe form of the disease, due to the involvement of the spleen, liver and bone marrow, and consequently clinical signs of hepatosplenomegalia, weight loss, pancytopenia, hypergammaglobulinemia and intermittent low-grade fever, of which fully symptomatic cases are considered life-threatening (GUERIN et al., 2002; READY, 2014). 
Up to date, 30 species of Leishmania were described and 21 of them are pathogenic for humans (WHO, 2017). According to Lainson and Shaw (1987), the genus Leishmania is divided into two subgenus: Viannia and Leishmania. This division is based on the position occupied by the parasite in the digestive tract of the vector, which may be in the region suprapillary or peripillary. Species of the subgenus Leishmania develop in the midgut and foregut, in the suprapillary region. Species of the subgenus Viannia develop in the foregut, midgut, and hindgut, in the peripillary region. This classification was proposed in 1987 and confirmed by a study of isoenzymes, considered the standard gold method (RIOUX et al., 1990), and more recently by a phylogenetic study based on the heat-shock protein 70 (FRAGA et al., 2010).

Visceral leishmaniasis is one of the deadliest parasitic diseases and disproportionately affects the poorest and most vulnerable populations (GUERIN et al., 2002). Despite, the global incidence of visceral leishmaniasis decreased substantially in the past decade: from between 200000 and 400000 new cases in 2012, to between 50000 and 90000 in 2017 (WHO, 2010), only in 2015, 23804 new cases of VL were reported to the World Health Organization (BURZA; CROFT; BOELAERT, 2018; WHO, 2017). The clinical importance of $V L$ resides in the severity of the disease that results in the death of underdiagnosed cases and even for individuals with treatment access, death occurs in 10 to $20 \%$ of the cases (DESJEUX, 2004; ALVAR et al., 2012). In Brazil, visceral leishmaniasis $(\mathrm{VL})$ is considered a zooanthroponosis formerly restricted to rural and peri-urban areas. With the emergence of outbreaks in urban areas, VL has assumed an important role in public health (MARZOCHI; MARZOCHI, 1994).

The parasite nomenclature of VL is still controversial. Lainson and Shaw (1987) proposed that visceral leishmaniasis is caused by parasites of the Leishmania (Leishmania) donovani complex. According to this classification, this complex includes L. (L.) donovani, L. (L.) infantum, L. (L.) chagasi and L. (L.) archibaldi. However, recently, this nomenclature has been very discussed. Based on genetic multifactorial studies, some authors suggest the possibility of $L$. chagasi to be a subpopulation of $L$. infantum derived from European strains (MAURÍCIO et al., 2000; MOMEN; CUPOLILLO, 2000; LAINSON; RANGEL, 2006; LUKES et al., 2007; SCHONIAN et al. 2010). In addition, studies developed by Leblois et al. (2011) suggest the origin of $L$. chagasi as a subpopulation of $L$. infantum from Portugal. Otherwise, Kuhls et al. (2011) indicate that $L$. infantum was introduced into the New World in multiple occasions from 
South-West Europe, suggesting that the causative agent of LV in the New World is $L$. infantum. Dantas-Torres (2006a; 2006b) suggests that L. chagasi should be considered as a synonymous of $L$. infantum until a new classification of the genus Leishmania is proposed, and this nomenclature was adopted in this thesis. It was also emphasized (DANTAS-TORRES 2006a; 2006b; SHAW, 2006; LAINSON; RANGEL, 2006) that the name Leishmania infantum chagasi entirely follows the rules of the International Code of Zoological Nomenclature (1999).

In the domestic dog (Canis lupus familiaris), infection by L. infantum causes canine visceral leishmaniasis (CVL), a parasitic zoonosis that is widely diffused in Latin American countries (ALVAR et al., 2004). The pattern of clinical signs of the disease in dogs may vary considerably, from animals apparently healthy or with inapparent infections, to those with evident clinical signs at several stages of the disease. Clinical manifestations include cutaneous alterations, such as alopecia, dermatitis, and onychogryphosis (BANETH et al., 2008; CIAMARELLA et al., 1997), and also visceral manifestations including splenic, renal, hepatic, and cerebral alterations that could lead to death (NIETO et al., 1992; GARCIA-ALONSO et al., 1996).

In addition, dogs play an important role in the epidemiology of human leishmaniasis, which is supported by the facts that cases of CVL have been reported in most of the countries where VL is endemic (ALVAR et al., 2004), canine cases usually precede the onset of human cases (BELVILACQUA et al., 2001), high rates of prevalence in dogs are reported, and the load of parasites is high in dog skin (MOLINA et al., 1994; GRAMICCIA; GRADONI, 2005). Therefore, dogs are considered the main urban and peri-urban reservoir host of $L$. Infantum, the etiological agent of VL (ALVAR et al., 2004; ALVAR et al; 2012; VERAS et al., 2014).

In Brazil, the Visceral Leishmaniasis Control and Surveillance Program (VLCSP) of the National Foundation of Health consists of three types of actions: 1) diagnosis and elimination of infected, asymptomatic or symptomatic dogs, aiming to reduce the source of infection to the vector sandflies; 2) early diagnosis and treatment of human patients; and 3) vector control in human cases areas. However, several studies have questioned the effectiveness of these actions, since the impact on human transmission is limited and costly (TESH et al., 1995; CAMARGO; LANGONI, 2006; SHIMOZAKO; WU; MASSAD, 2017).

In fact, despite the efforts to control the disease, a marked expansion of the VL in the last decades has been observed in Brazil, particularly in the North, Southeast 
and Midwest country regions (ALVES et al., 2018; MENON et al., 2016). Among the factors that have contributed to the expansion of the $V L$ and to reduce the effectiveness of control measures can be cited: 1) the environmental changes of the last decades, mainly characterized by increased deforestation, which favored the movement of sand flies and reservoirs to areas close to urban areas, and the uncontrolled growth of cities; 2) the migration of people and animals from the endemic regions to the unaffected areas; 3) Reduction of investments in health and education accompanied by discontinuation of control actions; and 4) the adaptation of parasites and vectors to new ecological niches (ALVES et al., 2018; (BURZA; CROFT; BOELAERT, 2018; MEMON et al., 2016; OLIVEIRA et al., 2018).

\subsection{PRESENTATION OF THE CHAPTERS}

In this context, this thesis, initially, presents a general literature review about the epidemiology of VL, in Brazil and in São Paulo state, as well some clinical and pathological aspects of CVL. The objective is not to offer a complete review about VL, but instead to highlight the main subjects that will be discussed on the other chapters. Subsequently, chapters four to six are written and formatted following selection of peer reviewed, international journals for publication.

Although the knowledge of the CVL has significantly progressed in the last decades, with the availability of new preventive measures, such as vaccination and insect repellents, and the improvement of information and education for the population, the disease continues to expand, reaching large urban centers throughout the country. Also, due to the lack of a straightforward diagnosis, a uniformly effective, safe and definitive therapeutic option and the paucity of prognosis factors, CVL continues to be a clinician and public health concern (ALVES et a., 2018). A crucial step for control strategies includes performing an accurate and early diagnosis of CVL to identify infected animals (COURA-VITAL et al., 2011; PODALIRI-VULPIANI et al., 2011). In this scenario, the Instituto Adolfo Lutz Instituto Adolfo Lutz, as a Central Public Health Laboratory and Research Institute, focus on innovation in scientific research, including the development of better diagnostic methods for diseases of public health interest. Therefore, chapter 4 of this thesis, entitle "Evaluation of cytopathological techniques for the diagnosis of canine visceral leishmaniasis in lymph nodes samples", describes the application of new methodologies to improve the diagnosis of CVL. Since, 
lymphadenopathy is a common clinical sign of the disease (ROGERS et al., 1993), fine-needle aspiration cytology of lymph nodes is a rapid and inexpensive direct diagnostic test for detection of Leishmania amastigotes (MYLONAKIS et al., 2005). However, parasite identification may be limited, depending on the clinical status of the animal, the parasite load and the prevalence of the disease (TAVARES VERAS et al., 2014). Thus, we applied the liquid-based cytology technique for the diagnosis of CVL, complemented with cell block and immunocytochemistry. The results were compared to conventional cytology, histopathology and immunohistochemistry. Besides, a variation of the diagnostic sensitivity related to the geographic region of the sample was evidenced, even without a significant statistical difference. This chapter will be submitted to the Journal of Comparative Pathology.

As so, a second approach aimed to study some critical points on the parasite host-interaction in the distinct eco-epidemiological scenarios of the CVL in São Paulo (SP) state, Brazil. In the northwest (NWSP) region, where the first autochthonous human cases were reported in Araçatuba in 1999, and since then, several other nearby municipalities have described a moderate to intense transmission of the parasite to humans and canines, besides the presence of the vector (CARDIM et al., 2013). And the other, in the southeastern (SESP) region of SP state, where a low prevalence of CVL has been detected in municipalities since 2003, sometimes without identification of human cases and vectors (CARDIM et al., 2013). Different chemotypes populations of Lu. Longipalpis and genotypes of Leishmania infantum, by multilocus microsatellite typing, were also recognized between NWSP and SESP (CASANOVA et al., 2015; MOTOIE et al., 2013). However, no reports concerning the vertebrate hosts in these two epidemiological patterns are described. Thus, chapter 5 address the differences in the immune response and parasite density of dogs naturally infected with $L$. infantum from different geographic location in the state of São Paulo. This chapter was prepared to be submitted to the Journal of Veterinary Immunology and Immunopathology.

Chapter 6, entitle "Evaluation of $L$. infantum genetic marker on chromosome 31 in dogs naturally infected in São Paulo state, Brazil”, focuses on another aspect of this parasite-host interaction through the study of a specific deletion in LinJ.31.2380 locus of $L$. infantum population from SP state in Brazil. The association between the genetic mutation to parasite load in popliteal lymph node tissues from dogs naturally infected with $L$. infantum from different eco-epidemiological scenarios of the disease were 
investigated. This chapter was prepared to be submitted to the Journal of Veterinary Parasitology.

Finally, the final considerations of the thesis briefly address the conclusion of the results presented in the previous chapters and also emphasizes the key points of interest that deserves further investigation.

\section{LITERATURE REVIEW}

$\mathrm{VL}$ is a severe systemic disease, extending from the eastern United States and Canada (DUPREY et al., 2006, CHAPPUIS et al., 2007; PETERSEN; BARR, 2009) to southern Argentina (MILLÁN et al., 2016). During 2001-2016, 55,530 human VL cases were reported in the Americas, with an annual average of 3457 cases (PAHO, 2018).

In 2016, 3354 cases of VL were registered in the Americas with an incidence rate of 1.04 and 4.51 cases per 100000 population, considering the total population and the population in the transmission area, respectively. Approximately $96 \%$ of the cases registered in the Americas are concentrated in Brazil. In the same period, there has been a geographic expansion in Argentina, Colombia, Paraguay and Venezuela. Regarding to the gender, of the total number of $V L$ cases, $66.3 \%$ (2223) were male. Concerning the age, the most affected age group was the children $<10$ years old with $39.1 \%$ (1313), followed by the $\geq 20<50$ years old (34.7\%) and the over 50 years old (16.96\%) age groups. In Colombia, Honduras and Venezuela, children under 5 years old were the most affected with $83.7 \%, 71.43 \%$ and $66.67 \%$ of the cases, respectively. Furthermore, the only two cases which occurred in Guatemala were of this same age group. There was also a $32 \%$ increase in the number of $V L$ and human immunodeficiency virus (HIV) coinfection cases with a total of 340 (10.14\%) cases; 316 were registered in Brazil, 19 in Paraguay, 4 in Colombia and 1 in Venezuela (PAHO, 2018)

Still, in 2016, 89.2\% (2993) of the cases were confirmed by laboratory diagnosis and $10.7 \%$ (361) by clinical and epidemiological criteria, showing an improvement in the first compared to the previous year (85.5\%). The recovery rate was $70 \%(2349)$ of the cases, representing a slight increase compared to 2015 (68.6\%). The 2016 fatality rate was $7.9 \%$ which is the highest rate recorded in America since 2012. During the period of $2012-2016,1187$ deaths by VL were reported to SisLeish, resulting in an average proportion of $7.09 \%$ deaths (MAIA-ELKHOURY et al., 2017; PAHO, 2018). 
Human VL cases have also been reported in Honduras (NAVIN et al., 1985). Sporadic and/or import human or canine cases were described in Chile (OSORIO et al., 1984), Ecuador (HASHIGUCHI; GÓMEZ LANDIREZ, 1991), Bolivia (DIMIERDAVID, et al.,1991), Mexico (TREJO-PÉREZ et al., 1993), Costa Rica (CARRILLO et al., 1999), and French Guyana (ROTUREAU et al., 2006). Since 2015, 33 autochthonous cases of CVL have been reported in Uruguay. However, VL prevalence/ incidence in Latin America is not exactly known because most countries lack effective surveillance systems (WERNECK et al., 2002; BERN; MAGUIRE; ALVAR, 2008; ZERPA et al., 2003).

\subsection{VISCERAL LEISHMANIASIS IN BRAZIL}

The first case of VL was reported in Brazil in 1913, in a patient from Boa Esperança, Mato Grosso, necropsied in Paraguay (MIGONE, 1913). More cases of the disease were only reported in 1934, based on post-mortem viscerotomy in 41 patients from the Northeast who had been suspected of yellow fever infection (PENNA, 1934). Until the early 1950s, only 379 cases of VL had been reported, distributed in 13 states, and it was believed that $\mathrm{VL}$ transmission was exclusively rural or sylvatic (CHAGAS, CHAGAS, 1938; ALENCAR, DIETZE, 1991). Late in this decade, the first cases of infected patients in peri-urban areas and CVL were described in the state of Ceará (DE ALENCAR, 1958; DE ALENCAR; HOLANDA; CAVALCANTE, 1956; DEANE; DEANE, 1955).

Since the 1970s, the urbanization of the disease has intensified, especially on the urban peripheries and in the so-called transition zones of medium and large cities (ALENCAR, 1983; LAINSON, 1983). It is believed that urbanization of VL results from anthropogenic environmental alterations and the rapid and intense migration of rural populations to urban peripheries that lack adequate housing and sanitation infrastructure, with the concurrent interaction and mobilization of sylvatic reservoirs and dogs infected with $L$. infantum to areas without VL transmission (SILVA et al., 1997; TAUIL, 2006). Furthermore, it has been observed that Lutzomyia longipalpis, responsible for transmission of the disease, has adapted easily to the peri-urban areas, and the factors that contributed to this are not still completely understood, but possibly related to those mentioned above, along with the maintenance of conditions favoring 
the vector's breeding in this setting and the species' development of capacity to cohabit anthropic environments (LAINSON, 1989; DIAS, LOROSA, REBELO, 2003).

Over the last 30 years, transmission of VL has been described in medium and large cities in various Brazilian municipalities, and in particular since the 1980s, cases and outbreaks of human VL have been reported, with indigenous transmission within city limits in São Luís (Maranhão), Teresina (Piauí), Natal (Rio Grande do Norte), Aracajú (Sergipe), Fortaleza (Ceará), Rio de Janeiro, Corumbá (Mato Grosso do Sul), and Montes Claros and Sabará (Minas Gerais). In the early 1990s, more municipalities reported outbreaks of VL in urban areas, as in Belo Horizonte (Minas Gerais), Feira de Santana (Bahia), Várzea Grande (Mato Grosso), Araçatuba (São Paulo), Aquidauana (Mato Grosso do Sul), and others. Since 2000, new urban epidemics have been reported in the municipalities of Palmas (Tocantins), Três Lagoas and Campo Grande (Mato Grosso do Sul), Caxias, Timon, Codó, and Imperatriz (Maranhão), Bauru (São Paulo), Paracatu (Minas Gerais), Cametá (Paraná), and others (BRASIL, 2004; SILVA et al., 1997; COSTA; PEREIRA; ARAÚJO, 1990; BEVILACQUA et al., 2001). Some of these urban VL outbreaks were attributed to the migration of families from the rural areas to the peri-urban slums after periods of prolonged drought (BEVILACQUA et al., 2001).

With the urbanization of VL, from 1980 to 2005, Brazil recorded 59129 new cases of the disease, with an annual mean of 2274 new cases. This number accounts for $90 \%$ of all reported VL cases in the Americas but is subject to substantial underreporting (BERN; MAGUIRE; ALVAR, 2008; BRASIL, 2008). Of all the cases, $82.5 \%$ (48783) occurred in the Northeast region. VL gradually spread to the CentralWest, North, and Southeast, increasing from 15\% of the cases in 1998 to $44 \%$ in 2005 (BRASIL, 2008). The recent increase in the incidence of registered VL in Brazil was expressive, in the 1980s, an average of 1500 new cases were reported each year in Brazil, and between 2000 and 2009, this average raised to 3480 cases annually, 132\% higher than 1980s. During the period of 2002-2009, fatality rate cases varied between $8.5 \%$ in 2003 and $5.6 \%$ in 2008, with an average of $7.0 \%$, compared to $3.2 \%$ in 1994 (DE ARAÚJO et al., 2012).

From 2006 to 2010, 18168 LV cases were recorded in the country. In 2010, the Northeast represented the majority of the cases $(47.1 \%)$, followed by the North $(18 \%)$, the Southeast $(17.8 \%)$, the Midwest $(8.6 \%)$ and the South $(0.1 \%)$. This progressive increase was registered in 21 Federative Units, reaching the five regions of the country 
(BRASIL, 2013). In the last years, the number of new cases reduced from 3597 cases in 2005 to 3200 new cases in 2016, with an incidence rate of 1.55 cases in 100000 habitants. However, in 2017, a slight increase in the number of cases was recorded, 4103 new cases in 23 out of the 26 federative states of Brazil, with an incidence rate of 1.98 new cases in 100000 habitants and mortality rate of $8.8 \%$ (BRASIL, 2017).

In recent years, the risk of LV and HIV co-infection has arisen (ASHFOR, 2000; DESJEUX, 2004). The first case of coinfection was reported in Europe in 1985 and since then the number of cases has increased considerably (ALVAR et al., 2008). This co-infection has already been reported in 35 countries, including Brazil. According to Sousa-Gomes et al. (2011), in 2007 and 2008, 7556 cases of VL were confirmed, with 278 cases (3.7\%) of VL and HIV co-infection. In $2017,7.8 \%$ of VL patients were also co-infected with HIV (BRASIL, 2017). This becomes a serious problem, since the cellular and humoral immunity of these individuals is diminished. These factors increase the risk of developing leishmaniasis with high parasite load in blood and bone marrow, low sensitivity in serological tests and high rates of treatment failure (ALVAR et al., 2008; CHAPMAN et al., 2015). Therefore, leishmaniasis has emerged as an opportunistic infection in patients with HIV and other individuals who also have immunosuppressive conditions (PEARSON; SOUSA, 1996).

According to Dujardin (2006), environmental changes, immune status and treatment failure are the three main risk factors for the emergence, re-emergence and spread of VL. Also, chemotherapy is considered a crucial factor for reducing the parasitic burden and the population of reservoirs of anthropoietic leishmaniasis. Therefore, increased treatment failures and the development of resistant strains are of great concern if we consider that leishmaniasis is a neglected disease and a small number of drugs are currently available for treatment.

\subsection{VISCERAL LEISHMANIASIS IN THE STATE OF SÃO PAULO}

In the state of São Paulo (SP), the first record of the presence of the Lutzomyia longipalpis was reported in a rural area in the municipalities of Salto de Pirapora, Pirapora do Bom Jesus and Cássia dos Coqueiros (FORATTINI; RABELLO; GALATI, 1976). Later, in 1978, Iversson et al. (1979) report the first autochthonous human case

- rare and isolated - of visceral leishmaniasis in Diadema, which surrounds the city of São Paulo. 
Until 1998, the LVA in the state of São Paulo came from cases imported from regions where this disease was already endemic (IVERSSON et al., 1982). The first autochthonous case of VL in the state was recorded in 1998 in a dog from Araçatuba, located in the northwest region of SP. In the following year, the autochthonous first human case of VL was recorded in the same region (TOLEZANO et al., 1999; CAMARGO-NEVES; SPÍNOLA; LAGE, 2003). The flow of people and services in railways, and especially in highways, seems to have a highlighted role in the spread of VL in SP. The construction of São Paulo's portion of the Bolivia-Brazil gas pipeline and the reactivation of Novoeste railway brought many workers from other states and countries to the region (CORREA ANTONIALLI et a., 2007). This migration of people also possibly triggered the migration of dogs infected by leishmania (MESTRE; FONTES, 2007).

The expansion of VL in São Paulo has been taking place in an eastbound direction, focusing on the role of highways, especially Marechal Rondon (CARDIM et al., 2013; CARDIM et al., 2016). Also, some cases of VL took place in the east of the state, next to the capital and in the coast. From 1999 to Abril 2017, 2857 autochthonous human cases and 246 deaths were confirmed, and the overall lethality was estimated in $8.6 \%$, higher than the lethality of VL in Brazil, which has oscillated between $5.4 \%$ and $7.8 \%$ in the period of 2006 and 2015 (RANGEL et al., 2013; RANGEL et al., 2015).

Considering the risk classification adopted by the Ministry of Health during the period from 2011 to 2013, of the 61 municipalities with human cases transmission, 42 $(68.9 \%)$ presented sporadic transmission, seven $(11.5 \%)$ moderate transmission (Junqueirópolis, Lins, Lucélia, Ouro Verde, Pereira Barreto, Tupã and Tupi Paulista) and $12(19.7 \%)$ had high incidence rates and were classified as having intense transmission (Adamantina, Andradina, Araçatuba, Bastos, Bauru, Birigui, Dracena, Jales, Oswaldo Cruz, Penápolis, Venceslau and Votuporanga) (CIAROVOLO et al., 2015).

In 2016, VL transmission was registered in 143 municipalities, 90 of these with human and canine transmission, six only presented human transmission and 47 with canine transmission (CVE, 2018). Data from 2017 indicated VL transmission in 151 municipalities in the state of São Paulo, with 93 municipalities presenting human and canine cases, five presenting autochthonous human cases without the presence of infected dogs and 53 only registered canine transmission (HIRAMOTO et al., 2019). The death of two children per VL was confirmed in 2016 and one case was recorded 
in 2017 in the county of Guarujá, on the coast of the state (HIRAMOTO et al., 2019). Also, there was an increase in the number of municipalities that registered the presence of the vector, which indicates an adaptation of the vector to the urban environment. This adaptation suggests an increased risk of transmission of CVL and, consequently, transmission to humans (CAMARGO-NEVES; SPÍNOLA; LAGE, 2003;). The presence of Lu. longipalpis was confirmed in 197 municipalities of the state, however, in the municipalities of Cotia and Embu there are records of other sandflies such as Pintomyia fischeri, Migonemyia migonei and Evandromyia edwardsi (CAMARGO-NEVES, 2007), which may be involved in the transmission of L. infantum in these regions.

Due to the expansion of VL in the state of São Paulo, the State Health Department of São Paulo developed the VL surveillance and control program in the state of São Paulo (PVCLVA). The general objective of the program is the reduction of the lethality rates and degree of morbidity. The PVCLVA is subdivided into areas related to epidemiological surveillance and measures of prevention and control of the vector, domestic and human reservoir (BRASIL, 2006).

Figure 1. Epidemiological classification of municipalities according to the Program of Surveillance and Control of Visceral Leishmaniasis in the state of São Paulo until December 2017.

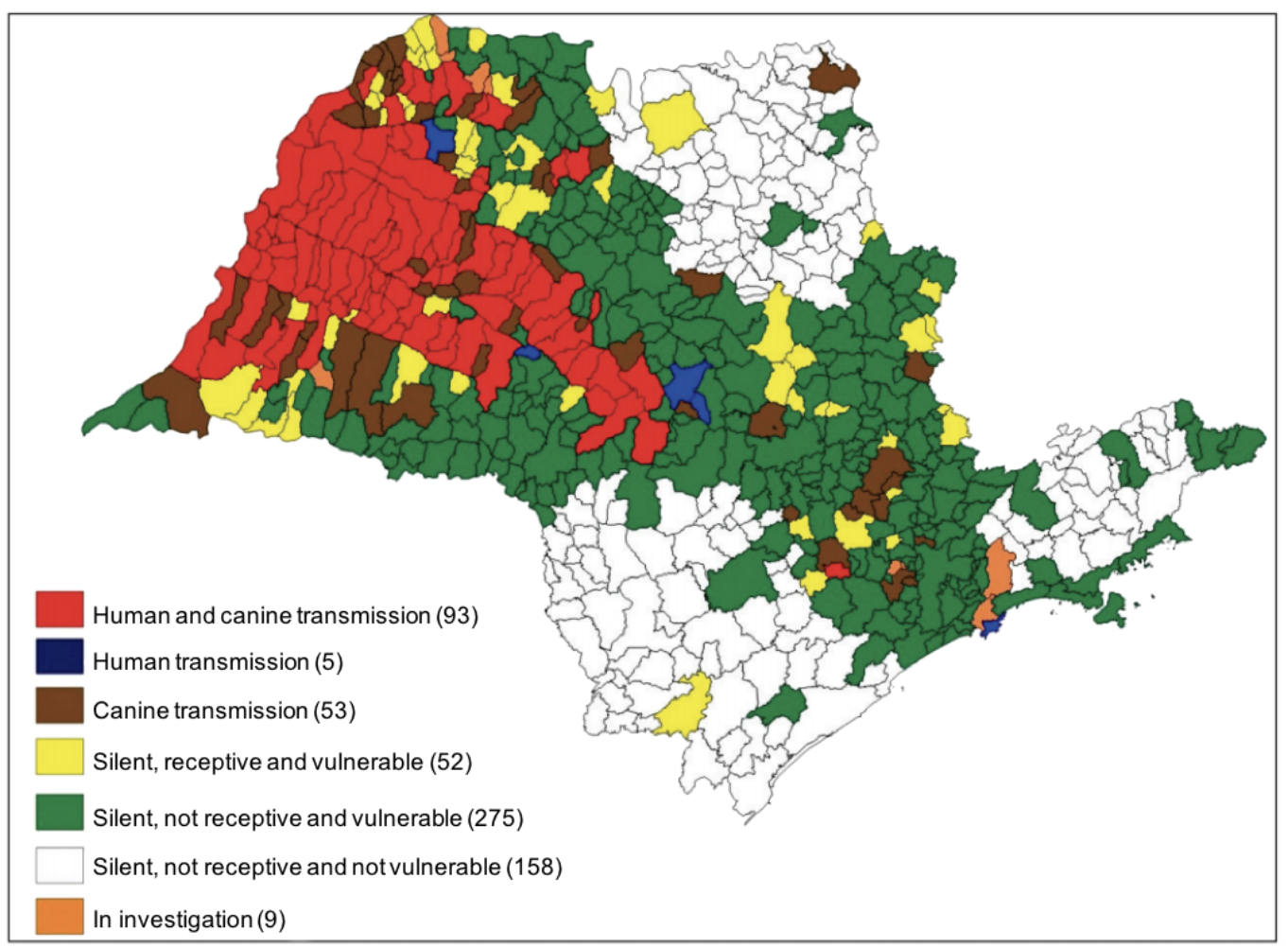

Source: Adapted from HIRAMOTO et al. (2019). 


\subsection{LIFE CYCLE AND TRANSMISSION}

The life cycle of Leishmania alternates between two main morphological forms: intracellular amastigotes in the mammalian host and motile promastigotes in the sandfly vector. When a sandfly takes a blood meal on an infected host, free amastigotes and intracellular amastigotes are ingested. In the midgut, these amastigotes transform into procyclic promastigotes which multiply and finally transform into metacyclic promastigotes which will migrate to the proboscis to infect another vertebrate at a next blood meal (KAYE; SCOTT, 2011; NIETO et al., 2011). By the time the female sandfly takes a new blood meal, the metacyclic promastigotes have affected its feeding mechanism in such a way that they cause regurgitation of midgut content - containing the parasites - into the feeding wound thereby ensuring efficient transmission to a vertebrate host (ROGERS et al., 2002). Infection occurs when sandflies take a blood meal on the host and transmit infective metacyclic promastigotes. Although most promastigotes will be rapidly eliminated by the host via complement-mediated killing (DOMINGUEZ et al., 2002), some are opsonized and taken up by macrophages. These organisms survive and differentiate into the amastigote form that will subsequently multiply and invade new cells. These promastigotes attach to mononuclear phagocytes or neutrophils and are taken up into a phagosome by phagocytosis. Next, the phagosome fuses with lysosomes to form a phagolysosome. Once the promastigotes are inside the macrophage, they transform into amastigotes, a tiny (2.5 - 5.0 to $1.5-2.0 \mu \mathrm{m}$ ), ovoid to round organism, which immediately start to divide by binary fission. Replication of amastigotes can cause rupture of the host cells and release parasites capable of invading other cells, like macrophages, dendritic cells or fibroblasts. Parasitized macrophages are mainly detected in the skin and reticulo-lymphatic organs (lymph nodes, spleen, bone marrow and liver) but can be present at other locations (GUPTA; NISHI, 2011). The complete life cycle of Leishmania is summarized in Figure 2.

Although Leishmania spp. is naturally transmitted through the bites of sandflies, other forms of transmission are possible. The uterine transmission from a dam to its offspring has been documented in a few clinical reports (SILVA et al., 2009), under experimental (ROSYPAL et al., 2005) and natural (PANGRAZIO et al., 2009) conditions. Venereal transmission from infected males to healthy bitches has also been documented (SILVA et al., 2009). 
Transmission by hematophagous arthropods other than sandflies has been reported but its epidemiologic significance is still in discussion. Rhipicephalus sanguineus ticks have been shown to acquire Leishmania spp. organisms in their guts after feeding on infected dogs (COUTINHO et al., 2005). The presence of $L$. infantum in the salivary glands of ticks and the presence of Leishmania spp. DNA and RNA were reported (COLOMBO et al., 2011; DANTAS-TORRES, 2008; SOLANO-GALLEGO et al., 2012). Also, natural transovarial and transstadial passage of $L$. infantum kDNA in ticks, Rhipicephalus sanguineus, blood feeding on a parasitemic dog, was confirmed by polymerase chain reaction (PCR) in Shiraz, south of Iran (DABAGHMANESH et al., 2016). Transmission of Leishmania spp. by fleas is suspected but still not proven (FERREIRA et al., 2009).

Blood transfusion (DE FREITAS et al., 2006; GIGER et al., 2002; OWENS et al., 2001) has been reported as a possible way of transmission and is of special concern due to a significant risk of blood collection from infected but clinically asymptomatic donors. Tabar et al. (2008) showed that $L$. infantum infection was quite common in canine blood donors and their blood products in an endemic area, despite a negative commercial serological screening for infectious diseases. The direct contact dog-to-dog transmission has been also suspected (DUPREY et al., 2006), especially in areas where sandfly vectors are absent. 
Figure 2. L. infantum life cycle. (1) During the bloodmeal from an infected vertebrate host, the female sand fly ingests free and intracellular amastigotes. In the midgut of the sandfly, the amastigotes transform into procyclic promastigotes. (2) The procyclic promastigotes multiply and transform into metacyclic promastigotes, the infective stage, that migrate towards the buccal cavity of the sandfly. (3) A bite from the sand fly transmits Leishmania promastigotes to susceptible mammalian hosts. (4) Promastigotes invade macrophages and dendritic cells, where they transform into intracellular amastigotes and replicate to produce a large number of parasites. (5) Consequently, the infected cell ruptures and releases amastigotes into the circulation. (6) Free amastigotes can infect other mononuclear phagocytic cells of the blood, spleen, liver, lymph nodes and bone marrow, and the life cycle is repeated

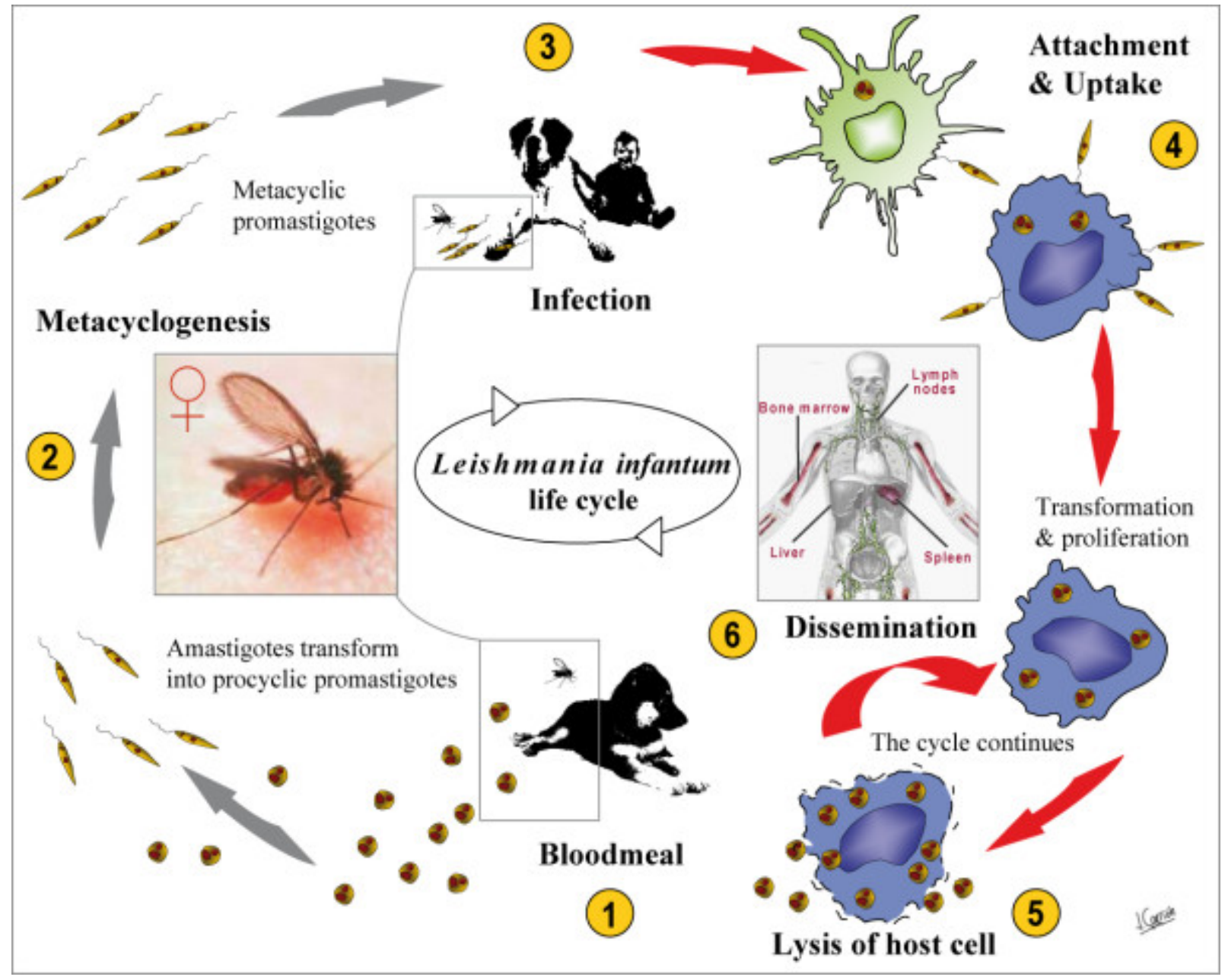

Source: Adapted from NIETO et al. (2011).

\subsubsection{The parasite}

Leishmania parasites have a genome architecture and associated biology that are unlike those of almost any other eukaryote. Trypanosomatids as a family appears to be a very ancient clade of the eukaryotic tree of life (AKHOUNDI et al., 2016; HE et al. 2014), and the whole class Kinetoplastida appear to have remarkably unique features. 
The genome of $L$. infantum and $L$. donovani is composed of 36 chromosomes and characterized by a high degree of syntenia, genes organized in polycistronic transcription units, rare spliceosomal introns and shorter subtelomeric regions (WINCKER et al., 1996; PEACOCK, SEEGER; 2007; ROGERS et al., 2011). According to González-de la Fuente et al. (2017) the genome of $L$. infantum reference strain JPCM5 (MCAN/ES/98/LLM-724) has 32,802,969-bp with 8796 annotated genes (including also non-coding RNAs). Overall, the genome structure is remarkably consistent across species, with conserved synteny observed for approximately $99 \%$ of all genes. Only $\sim 200$ genes are distributed in different regions of the genome in $L$. major, L. infantum, and L. braziliensis. Coding regions in L. major and L. infantum share up to $92 \%$ of the amino acid sequence, and $94 \%$ of the nucleotide sequence (PEACOCK, SEEGER; 2007).

Also, kinetoplastid organisms possess a kinetoplast-localized genome known as kDNA, which codes for mitochondrial metabolic enzymes involved in cellular respiration. The kDNA is organized into a network of interlocked minicircles and maxicircles. The minicircles, which are smaller $(\sim 1 \mathrm{~kb})$ and more numerous $(\sim 100$ copies), code for guide RNAs, while the maxicircles, which are larger ( $25 \mathrm{~kb})$ and less abundant ( $\sim 0$ copies), code for pre-mRNAs (HAJDUK; OCHSENREITER, 2010; APHASIZHEV; APHASIZHEVA, 2011).

Gene expression studies have found a small number of genes differentially expressed between the promastigote and the amastigote stages. Global interspecies expression analyses have found that the majority of genes are differentially regulated throughout development in one species, however, they may be not differentially regulated in others (ROCHETTE et al., 2008). In both L. major and L. infantum, only 7$9 \%$ of the genome is differentially expressed in these two life stages, according to oligonucleotide microarray data (ROCHETTE et al., 2008). Interestingly, $43 \%$ up to $95 \%$ of the small set of genes found to be differentially expressed in L. infantum promastigotes are no longer differentially expressed if parasites are isolated from axenic culture as opposed to the sand fly midgut (ALCOLEA et al., 2014), suggesting a significant bias introduced by in vitro culture.

In addition, since the 1990s, there has been ongoing debates on the mating system and population structure of eukaryotic microbial pathogens such as Leishmania. These two biological aspects are closely linked to each other and have important consequences for the epidemiology of transmissible diseases (TIBAYRENC; 
KJELLBERG; AYALA, 1990; TIBAYRENC; AYALA, 1991; TIBAYRENC; AYALA, 2013). According to Tibayrenc et al. (1990), VL is mainly caused by a single clone (zimodema MON 1). However, current studies demonstrate a low number of heterozygotes in Leishmania population, which is theoretically incompatible with a clonal population model and Meselson effect (FERREIRA et al., 2012; ROUGERON et al., 2010; SEGATTO et al., 2012). According to it, in the absence of sexual reproduction, the two copies would accumulate mutations over time, leading to a divergence between the alleles of a loci and increase heterozygosity (BALLOUX; LEHMANN; DE MEEÛS, 2003; BIRKY, 1996; JUDSON; NORMAK, 1996).

In addition, other studies suggest that recombination may occur in Leishmania (BAÑULS et al., 2007; KUHLS et al., 2008). Akopyants et al. (2009) infected sandflies with transgenic strains of $L$. major resistant to two different drugs that were used as markers and they showed that the parasite is capable of maintaining a sexed cycle in the phlebotomine. Hybrids resistant to both drugs were transmitted to the vertebrate host by vector bite. In $38.39 \%$ of obtained clones, three sets of chromosomes were observed, characterizing a triploidy. Therefore, alternative genetic mechanisms must also be considered. The researchers also infected mice with these transgenic strains but could not recover resistant parasites to any of the drugs. Evidence of the occurrence of hybrid strains of $L$. braziliensis and L. panamensis (BELLI et al., 1994), L. braziliensis and L. guyanensis (BANŨLS; HIDE; TIBAYRENC, 1999; DELGADO et al., 1997), L. braziliensis and L. peruviana (DUJARDIN et al., 1995; NOLDER et al., 2007), L. infantum and L. major (RAVEL et al., 2006) were also reported. In addition, Volf et al. (2007) experimentally demonstrated that hybrids of $L$. infantum and $L$. major can develop in phlebotomine Phlebotomus papatasi, a vector of $L$. major. Also, high infection rates, heavy parasite loads and late-stage infection with colonization of the stomodeal valve were observed in Phlebotomus tobbi infected by $L$. infantum/L. donovani natural hybrid, a dermotropic strain identified in Turkey (CUK strain) (SEBLOVA et al., 2015).

Hybridization may favor the adaptation of the parasite to new ecological niches, vectors and hosts and the dissemination of new genetic characteristics. Therefore, reproduction of Leishmania seems to combine hybridization with clonal expansion (BAÑULS; HIDE; TIBAYRENC, 2002; MILES et al., 2009; SÁDLOVÁ; VOLF, 2009).

Also, many molecular methods have been developed to evaluate the genetic diversity of Leishmania parasites. These include the amplification of DNA sequences 
of the parasite by specific polymerase chain reaction (PCR), the random amplification of polymorphic DNA (RAPD) (HIDE; BAÑULS; TIBAYRENC, 2001; ZEMANOVA et al., 2004), simple sequence repeats-PCR (SSR-PCR) (OLIVEIRA et al., 1997; DE OLIVEIRA et al., 2007), PCR of antigen-encoding genes (gp63 and cpb) followed by analysis of restriction fragment length polymorphism (RFLP) (MAURICIO et al., 2001; QUISPE-TINTAYA et al., 2004), PCR-RFLP of kinetoplast DNA (kDNA) minicircles (MORALES et al. 2001; CHICHARRO et al., 2002) and, more recently, multilocus microsatellite typing (MLMT) (OCHSENREITHER et al. 2006; ALAM et al., 2009; MOTOIE et al., 2003).

Several studies showed that genetic variability of $L$. infantum in Brazil is low, with restricted diversity and limited population clustering. In a recent work assessing parasite populations distributed over 18 states, three major clustered populations could be inferred using microsatellite typing. When the analysis is performed in parasites from closely related geographic regions, the overall diversity is even lower (FERREIRA et al., 2012; SEGATTO et al., 2012; BATISTA et al., 2012; RIBOLLA et al., 2016). In the state of São Paulo, there are two main genetic clusters circulating with strong genetic differentiation, one is composed by samples from the southeast and the northwest region and presented a weak signal of the geographical substructure. The other, belongs to the same cluster found in the state of Mato Grosso do Su, which represents the majority $(93.75 \%)$ of parasite genotypes in this state (MOTOIE et al., 2013).

\subsubsection{Invertebrate hosts (vectors)}

The vectors of leishmaniasis are dipterous insects classified in Psychodidae family and in the Phlebotominae subfamily (BATES, 2007; REY, 2010). Only females are transmitters of Leishmania, since they require proteins present in the blood of the vertebrate host to carry out ovoposition (DESJEUX, 2004; MORAES et al., 2018). As transmitters of leishmaniasis, the genera Phlebotomus in the Old World and Lutzomyia in the New World are the major concerns (REY, 2010; BADARÓ; DUARTE, 2005). In the Americas, despite the 521 sandflies species recognized (GALATI, 2014), 60 of which have been implicated as Leishmania vectors, only a few of them are considered proven vectors of the parasites and the sandflies $L u$ Longipalpis is considered the main vector of LVA (LAINSON; SHAW, 1987; DOS SANTOS et al., 1998; SOARES; 
TURCO, 2003). However, in northern Colombia and Venezuela, Bejarano et al. (2001) described $L u$. evansi as the main vector. In addition, it should be highlighted the evidence that $L u$. longipalpis can be a complex of species according to morphological studies, per (period) gene analysis, pheromones and male singing during intercourse (WARD et al., 1983; BAUZER et al., 2007; ARAKI et al., 2009).

In Brazil, chemical, behavioral and ecological analysis of male-produced sex pheromones suggests that Lu. longipalpis is a complex of at least four different, reproductively isolated members (HAMILTON et al., 2005; WARD et al., 1988; WARD; MORTON, 1991). Two of these are represented by members where the males produce either 3-methyl-a-himachalene (HAMILTON et al., 1999), a novel bicyclic methylsesquiterpene found in Jacobina, Bahia state, or (S)-9-methylgermacrene-B (HAMILTON et al., 2010) and a novel monocyclic methylsesquiterpene that is widely distributed throughout Brazil but typically represented by $L u$. longipalpis from Lapinha Cave, in the state of Minas Gerais. The other two members of the complex produce novel diterpenes, cembrene-1 and cembrene-2 and are represented by the Sobral-2S population from Ceará state and the Jaíbas-1S population from Minas Gerais state (HAMILTON; BRAZIL; MAIGON, 2004). Two of these chemotype populations, (S)-9methylgermacrene-B and cembrene-1, have been identified in São Paulo state (CASANOVA et al., 2006; CASANOVA et al., 2015).

Genetic analyses, as the per gene, was considered a useful molecular marker in studies of population genetics, and even more so considering the additional evidence from pheromones and copulation song analysis (BAUZER et al. 2002, ARAKI et al. 2009) and the fixed polymorphisms detected in nearby populations in Northeast Brazil (LIMA-COSTA JR et al. 2015). Also, analysis of the sequence variation in the mitochondrial cytochrome b gene among $L u$. longipalpis populations collected from regions with different patterns of transmission of visceral leishmaniasis showed significant differentiation, that may have implications with respect to their efficiency as vectors for visceral leishmaniasis (ROCHA et al., 2011).

Therefore, the wide variety of evidence, including chemical, behavioral and molecular traits, suggests very recent speciation and complex population structure in the Lu. longipalpis species complex. Although significant advances have been achieved to date, differential vectorial capacity and the correlation between genetic structure of parasite and vectors populations remain to be elucidated (SOUZA; BRAZIL; ARAKI, 2017). 
In addition, currently the relevance of secondary vectors has been very discussed, based on epidemiological criteria and detection of natural infection by molecular methods (KAMHAWI, 2006). In the state of Mato Grosso do Sul, in the cities of Corumbá and Ladário, Lu. cruzi and Lu. forattini are pointed as main and secondary vectors, respectively. (GALATI et al., 1997; DOS SANTOS et al., 1998; PITAPEREIRA et al., 2008). In this same state, in Serra da Bodoquena, Lu. almerioi also appears to act as a secondary vector (SAVANI et al., 2009). In the state of Mato Grosso, cases of Lu cruzi infected by $L$. infantum have been reported (MISSAWA et al., 2011). And recently, Migonemyia migonei was indicated as a putative vector in the state of Pernambuco (DE CARVALHO et al., 2010) and northern Argentina (DE CARVALHO et al., 2010; MOYA et al., 2015; SALOMÓN et al., 2010). In this scenario, there is a hypothesis of the existence of other sandflies species that may also be acting as permissive vectors in the transmission of the various species of Leishmania. In Cotia and Embu das Artes, municipalities of the São Paulo metropolitan area, CVL cases have been reported since 2003, but Lu. longipalpis has not been found in the entomological surveys undertaken in these foci (LINO et al., 2003; CIARAVOLO et al., 2015), and Pi. fischeri could be a potential vector of this parasite in these regions (GALVIS-OVALLOS et al., 2017). DNA of $L$. infatum was identified in one Expapillata formatoi and two Pintomyia monticola from Campinas, a city of São Paulo state, through a specie-specific polymerase chain reaction ate (SILVA, 2016).

\subsubsection{Vertebrate hosts (reservoirs)}

$V L$ has been documented in several mammalian species in zoo and wildlife animals (SOUZA et al., 2014), including carnivores (BECK et al., 2008; LUPPI et al., 2008; RICHINI-PEREIRA et al., 2014), primates (MALTA et al., 2010), marsupials (SANTIAGO et al., 2007), edentates (DE ARAÚJO et al., 2013), lagomorphs (MOLINA et al., 2012), bats (LIMA et al., 2008), rodents (PAPADOGIANNAKIS et al., 2010), and horses (ROLÃO et al., 2005). Although the domestic dog is the most important vertebrate host and the main urban and peri-urban reservoir of $L$. infatum, several other wild mammal species are susceptible to parasitic infection. In many regions, other canids such as jackals, foxes, wolves and other mammals, such as hares or black rats, have been implicated as wild reservoirs (MILLAN et al., 2014). Wild animals are subjected to challenges imposed directly or indirectly by the anthropic influence that 
impacts ecosystems and may exposure wildlife to pathogens, which under some circumstances may lead to or increase the risk of extinction of a given species. Importantly, wild animal health reflects environmental health and may serve as an indicator of human risk of exposure to zoonosis in that environment (AGUIRRE, 2009). Therefore, the importance of wild animals as sentinels must be considered, although analytical methods for linking animal and human data, thus predicting human risk are still underdeveloped (SCOTCH et al., 2009). Zoo animals maintained in captivity in endemic urban environments are under high risk of infection, and therefore diagnostic tests are advised for prevention and control of the disease in zoo populations, especially when exchanging or introducing susceptible animals (MALTA et al., 2010; JUSI et al., 2011; LIBERT et al., 2012). In addition, feline leishmaniasis has been reported in many countries where the canine and human disease is endemic, and it has been suggested that domestic cats may receive greater attention as a public health risk (MAIA et al., 2008; MARTIN-SANCHEZ et al., 2007; PENNISI et al., 2015).

\subsection{CANINE VISCERAL LEISHMANIASIS}

Canine visceral leishmaniasis (CVL) is a severe systemic disease whose clinical manifestations are intrinsically dependent on the type of immune response expressed by the infected animal. The clinical manifestation of the infected dogs presents a spectrum of clinical characteristics ranging from the apparent healthy state to a severe end-stage disease (BRASIL, 2006).

Since 1908, when they reported for the first time the presence of amastigote forms in domestic canids (NICOLLE; COMTE, 1908) and in Brazil when they observed intense cutaneous parasitism in dogs and foxes of Ceará (DEANE and DEANE, 1955), domestic dogs (Canis lupus familiaris) have been considered as important urban and peri-urban reservoirs for $L$. infantum infection.

The high prevalence of canine disease in endemic areas for $V L$, the identification of dog infection before the occurrence of human cases and the intense cutaneous parasitism presented by these animals, highlight the important role of dogs in the epidemiology of VL (COURTENAY et al., 2002; MORENO; ALVAR, 2002; GIUNCHETTI et al., 2006). 


\subsubsection{Clinical disease spectrum}

Infected dogs can present different clinical features ranging from apparently healthy (asymptomatic dogs) to several characteristic multisystemic clinical signs (symptomatic dogs) (MANCIANTI et al., 1988). Dogs from all breeds can be infected with leishmaniosis, however, symptomatic infection is uncommon in young immature animals. The age distribution of the disease is bimodal with a peak of prevalence at 24 years and a secondary peak from the age of 7 years (SOLANO-GALLEGO et al., 2011).

Skin lesions are the most frequent manifestations affecting approximately 50 to $90 \%$ of symptomatic dogs (SOLANO-GALLEGO et al., 2001; KOUTINAS et al., 1999; SHAW; LANGTON; HILLMAN, 2009; SOLANO-GALLEGO et al., 2011), including dry exfoliative dermatitis (56\%), ulcers (40\%), diffuse alopecia (14\%) and/or periorbital alopecia (18\%) (CIARAMELLA et al., 1997). These lesions can be generalized or localized, especially, in muzzle, periorbital ("periocular lunettes"), aural and limbs regions (KOUTINAS et al., 1999; ORDEIX et al., 2005). Also, changes in skin appendages could be observed, such as onychogryphosis, in 30 to $75 \%$ of cases (ALMEIDA et al., 2005), swelling of the footpad and nasodigital hyperkeratosis. From the localized cutaneous infection, the parasite can be disseminated via lymphatic or blood vessels, infecting macrophages of the bone marrow, lymph node, liver and spleen, as well as kidney and gastrointestinal tract (TRYPHONAS et al., 1977; KEENAN et al.; 1984a). Weight loss may also be present, as well as cachexia and anorexia, in 25 to $80 \%$, and ocular abnormalities in 16 to $24 \%$ (ALMEIDA et al., 2005). Fever, apathy, diarrhea, epistaxis, intestinal bleeding, generalized lymphadenopathy, hepatosplenomegaly are typically systemic clinical signs related to CVL. Masticatory

muscle atrophy, polyarthritis, glossitis, stomatitis, myocarditis, meningoencephalomyelitis, orchitis, epididymitis and/or prostatitis could be also found in affected animals (CIARAMELLA et al., 1997; KOUTINAS et al., 1999). In the final stages of the disease, signs of renal failure may develop, such as anorexia, polyuria/polydipsia and vomiting (TAVARES VERAS et al., 2014).

Also, the incubation period can vary extensively, as host factors influence the parasite spread and multiplication, it may take between two months to many years for symptoms of the disease to become apparent (DELANEY et al., 1935; SLAPPENDEL, 1988). Only a few metacyclic promastigotes delivered at the site of sandfly bite survive 
and transform into intracellular amastigotes (WARBUG et al., 1986), therefore, it takes some time for the parasites to multiply and spread from the site of infection. The long and variable latent period complicates epidemiological and intervention studies in the field (HOSEIN; BLAKE; SOLANO-GALLEGO, 2017). A cohort study in Italy showed that whatever the dog breed and the local incidence of leishmaniasis, any asymptomatic active infections detected in naive animals invariably progress to fullblown disease, showing a common pattern of early and late signs for 2 years post infection (FOGLIA MANZILLO et al., 2013).

Classically, researchers use the clinical classification of asymptomatic, oligosymptomatic and polysymptomatic based only on physical examination (MANCIANTI et al., 1988). This classification appears to be of limited value because it does not consider clinicopathological abnormalities and disregards dogs that have widespread organ dysfunction without apparent visual manifestations (MELÉNDEZLAZO et al., 2018). In developing a clinical staging model for CVL, Solano-Gallego et al. (2009) reviewed and focused on several aspects of this disease and proposed a system of four clinical stages (I to IV and 2 substages, A and B), based on clinical signs, clinicopathological abnormalities (with evaluation of renal function according to the recommendations of the International Renal Interest Society, IRIS), and serological status. Prognosis and appropriate therapy were classified according to the stage. Subsequently, in 2010, the Canine Leishmaniasis Working Group (CLWG) proposed classification of dogs with positive serological tests, or those in which the parasite had been identified via direct diagnostic methods, into 4 stages ( $A$ to $D$ ), including, unlike the previous system, asymptomatic dogs as well as those with clinical signs (PALTRINIERI et al., 2010). The proposed classification system divided dogs into groups of: exposed, infected, sick and severely sick dogs, with only two stages for dogs with clinically evident leishmaniasis. In 2013, the CLWG reviewed the classification adding stage $E$ for dogs unresponsive to treatment or dogs with early relapse and used the staging system to formulate a prognosis and monitor subjects depending on the stage of disease (ROURA et al., 2013).

\subsubsection{Immune response}

The diversity of clinical manifestations expressed in leishmaniasis derives from a complex interaction between the parasite and the host's immune system. In the last 
decade, various research groups have concentrated efforts studying immunopathology of dogs naturally and experimentally infected by L. infantum, however, the precise immune mechanisms responsible for resistance or susceptibility to infection and subsequent disease are not fully understood (HOSEIN; BLAKE; SOLANO-GALLEGO, 2017).

Nonetheless, it appears that factors such as breed, immunosuppression, concomitant disease and nutritional status can influence the outcome of infection (MIRÓ et al., 2008). Similarly, the presence of ongoing co-infections with pathogens or previous infections appear to be associated with more clinical signs and clinicopathological abnormalities and disease severity (CORTESE et al., 2011; MEKUZAS et al., 2009; TABAR et al., 2013). Other factors that might determine the outcome of infection includes the virulence of $L$. infantum parasites (MARTIN-MARTIN et al., 2015), inoculum of parasites, sandfly transmission or other routes of transmission. In fact, the outcome of the disease is strongly influenced not only by inherent characteristics of the infective strain but also by the fitness of the immune system in generating a protective response (ROSSI; FASEL, 2018).

Innate and adaptive immunity play essential roles in the outcome of $L$. infatum infection. The primary strategy that the host presents to fight against Leishmania is non-specific and relies on innate mechanisms of the immune response. It has long been known that the complement system plays a significant role in the eradication of promastigotes in the bloodstream of an infected host (REZAI; SHER; GETTNER, 1969). However, promastigote antigens from the surface glycocalix-like gp63 protease (leishmanolysin) or the lipophosphoglycans are known to provide specific resistance to complement-mediated lysis (HALLÉ et al., 2009). Also, amastigotes released from disrupted macrophages use opsonization with lgG's Fcy moiety to enter in new macrophages without triggering their activation through ligation to $\mathrm{Fcy}$ receptor (MOREHEARD et al., 2002). Neutrophils are the first host cells to reach the site of Leishmania infection within a few hours of inoculation by a sandfly bite (MÜLLER et al., 2001; POMPEU et al., 1981). They have been shown to actively engulf Leishmania promastigotes (MOLLINEDO et al., 2010; PEARSON; STEIGBIGEL, 1981) and produce an array of microbicidal factors against Leishmania such as nitric oxide (CHARMOY et al., 2007), neutrophil elastase (RIBEIRO GOMES; SACKS, 2012), platelet activating factor (CAMUSSI et al., 1987), and neutrophil extracellular traps (GUIMARÃES-COSTA et al., 2009). Neutrophils generally have a protective role in 
most forms of Leishmania infections (DE SOUZA CARMO; KATZ; BARBIÉRI, 2010; NOVAIS et al., 2009), although outcomes are dependent on the Leishmania strain, the genetic background of the host and the apoptotic or necrotic state of the neutrophils (AFONSO et al., 2008; DE SOUZA CARMO; KATZ; BARBIÉRI, 2010; FILARDY et al., 2010; NOVAIS et al., 2009; RIBEIRO GOMES et al., 2004).

Early on during Leishmania infection, natural killer (NK) cells are also recruited to the infected site after neutrophil recruitment (MÜLLER et al., 2001; THALHOFER et al., 2011). They are the primary source of early IFN-y that favors the Th1 differentiation of CD4 ${ }^{+} \mathrm{T}$ cells (SCHARTON; SCOTT, 1993) and restricts early parasite dissemination (DIEFENBACH et al., 1998; LASKAY et al., 1995). NK cells can also mediate direct parasite lysis through its cytotoxic activity (LIEKE et al., 2011) and subsequently contribute to cytokine-mediated inducible nitric oxide synthase induction in Leishmania-infected macrophages (PRAJEETH et al., 2011).

Inflammasome is a complex of protein associated to caspase- 1 related to innate response to microorganisms and to secretion of IL-1 $\beta$, a pro-inflammatory cytokine, but its role in leishmaniasis progression remains controversial (LIMA-JUNIOR et al., 2013). Inflammasome activation and IL-1 $\beta$ production have recently been shown in murine models to be critical for host resistance to infection with diverse Leishmania species, including Leishmania amazonensis, Leishmania braziliensis, and Leishmania infantum (LIMA-JUNIOR et al., 2013). However, NIrp3 inflammasome-dependent IL$1 \beta$, associated with localized neutrophil recruitment, seems to play a crucial role in the development of a nonhealing form of cutaneous leishmaniasis in conventionally resistant mice (CHARMOY et al., 2016). Moreover, Patil et al. (2018) demonstrated that prolonged exposition of macrophages to IL-1B increases parasite burden and favors disease infection, in experimental infection with Leishmania major, inoculated in murine model. In humans with cutaneous leishmaniasis (Leishmania mexicana), different levels of IL-1 $\beta$ was also associated with clinical profiles: patients with a more severe form had higher levels of IL-1 $\beta$ in serum. Also, in this same study, microscopically, IL-1 $\beta$ was confined to cells in low parasite burden, while it was scattered diffusely in lesions associated to high count of parasites (FERNÁNDEZFIGUEROA, et al., 2012).

CVL is often associated with a marked humoral response, which is nonprotective and denotes failure to control the infection. The levels of Leishmania-specific immunoglobulins are greater in sick dogs compared with sub-clinical dogs (PALATNIK- 
DE-SOUSA et al., 2004). A marked association was seen between these levels, tissue parasite density and the clinical status of the animal (REIS et al., 2006b). Over the years, the levels of canine IgG subclasses; IgG1 and IgG2, have been extensively researched in an attempt to establish a correlation between the type of Th response, the subclass level and the final clinical outcome of infection (BANETH et al., 2008). Despite controversial findings regarding the immunoglobulin isotype profile associated with CVL, studies have displayed a stable increase in the production of both these subclasses during natural and experimental infection with no indication of practical use (QUINNELL et al., 2003; REIS et al., 2006b; STRAUSS-AYALI; BANETH; JAFFE, 2007). Rodriguez-Cortes et al. (2007) reported that the intensity of $L$. Infantum infection in blood samples was significantly correlated with clinical signs and $\lg$, IgA and IgM concentrations.

Therefore, the ability of the host to control $L$. infantum infection requires the generation of cell-mediated immune responses, which activate host macrophages, eliminating intracellular parasites (HOSEIN; BLAKE; SOLANO-GALLEGO, 2017). An enriched inflammatory environment with chemokines and cytokines is fundamental to attract, activate and maturate dendritic cells and macrophages, turning them into antigen-presenting cells. These phagocytes express the major histocompatibility complex and costimulatory molecules. The interleukins released Analysis of the immune response in peripheral blood cells described protective cell-mediated immune responses that were associated with the activation of Th1 cells, producing IFN- $y$, IL-2 and TNF- $\alpha$, and active disease characterized by mixed Th1/Th2 responses (PINELLI et al., 1994; 2000; REIS et al., 2006a; CARRILLO; MORENO, 2009). However, further studies indicated that the Th1, Th2 or mixed Th1/Th2 immune responses to the parasites were in-fact organ specific (REIS et al., 2009), and it could be correlated with the absence or presence of clinical signs and parasite load data (STRAUSS-AYALI; BANETH; JAFFE, 2007; TRAVI et al., 2009; BOGGIATTO et al., 2010). Therefore, the phenotypic cell profiles and cytokines involved in immune responses, in compartments where parasites are known to replicate, have variable effects on local parasite control, highlighting the complexity of cellular immune responses in L. infantum infection (MAIA; CAMPINO, 2012).

Aiming to better understand events related to compartmentalized immunopathology of CVL, several research groups have performed a broad investigation focusing on histopathological, parasitological and immunological aspects 
of lymph nodes (LN), skin, spleen and liver in dogs naturally and experimentally infected by L. infatum (REIS et al., 2009).

There are only a few studies focusing on the LN during CVL (KEENAN et al., 1984a; 1984b; MARTINEZ-MORENO et al., 1993; TAFURI et al., 2001; LIMA et al., 2004; GIUNCHETTI et al., 2008). In this disease, lymphadenopathy is usually defined as an increase in LN size (enlargement of LN), usually described as a regional or generalized alteration (ROGERS et al., 1993). It has been demonstrated that all LN from $L$. infantum-infected dogs display a chronic lymphadenitis, regardless of the anatomical region analyzed, with hypertrophy/hyperplasia of cortical and medullary zones (LIMA et al., 2004). However, the clinical status or the tissue parasitism load might not be directly related to the intensity of the lesions, once previous data demonstrated that asymptomatic group presented higher $\mathrm{LN}$ parasitism than oligosymptomatic or symptomatic groups (GIUNCHETTI et al., 2008). In popliteal LN, a balance was observed between the percentage of IL-10 and TNF- $\alpha$ expression, which was possibly attributed to an absence of clinical signs and low parasite loads (MAIA; CAMPINO, 2012). This was similar to earlier findings where lymph nodes from sub-clinical dogs had a high expression of pro-inflammatory cytokines, which was correlated with a low number of parasites. The authors suggested a role for IL-10 and TGF- $\beta$ in disease progression (ALVES et al., 2009). In a study by Barbosa et al. (2011), they reported that asymptomatic dogs showed high expression of genes encoding IL2 and IL-12 in lymph nodes. Hosein et al. (2015) reported down-regulation of IL-22 with disease progression in an experimental CanL model. Giunchetti et al. (2008) reported that lymph node CD8+ T cells might be involved in a distinct activation status during CVL which was most likely associated with immunomodulatory or suppressor cell activity. Alexandre-Pires et al. (2010) demonstrated that CD8+ T subpopulations in lymph nodes from treated dogs were significantly lower than in asymptomatic nontreated dogs. In addition, they reported that the CD4+ T cell subset in lymph nodes of both treated and asymptomatic dogs was significantly higher than that in control, noninfected dogs. These findings possibly indicate that an increase in CD8+ T cells is associated with parasite persistence, whereas CD4+ subpopulation expansion favors control of the parasite (ALEXANDRE-PIRES et al., 2010; MAIA; CAMPINO, 2012).

\subsubsection{Diagnosis}


The diagnosis of CVL is complex because of the broad and often nonspecific spectrum of clinical signs and clinicopathological abnormalities (SOLANO-GALLEGO et al., 2011). Subclinical infections provide an added complication, as the prevalence of infection in healthy dogs is often several times higher than that of clinical leishmaniasis (BANETH et al., 2008). As so, diagnosis of CVL should be based on an integrated approach considering signalment, history, clinical findings, clinicopathologic changes and results of direct and indirect etiologic diagnostic tests (CASTAGNARO et al., 2007). Recently, the use of vaccines against CVL in endemic areas poses an additional diagnostic challenge if the vaccine promotes seroconversion detected by conventional diagnostic tests, as well as in some cell-mediated immunity assays.

\subsubsection{History, clinical signs, physical examination and clinical laboratory abnormalities}

History collection is included information about clinical signs noted by the owner and consistent with CVL, including weight loss, asthenia, dermatological changes, polyuria-polydipsia and epistaxis (CASTAGNARO et al., 2007). Although individual symptoms of leishmaniasis are mostly non-specific, a dog exhibiting a combination of a wide and heterogeneous range of clinical disease signs is likely to be adequately diagnosed by those that are familiar with the disease (SLAPPENDEL et al., 1988; CIAMARELLA et al., 1997; KOUTINAS et al., 1999; SOLANO-GALLEGO et al., 2001). However, depending on the symptoms that are present, leishmaniasis may be difficult to distinguish from other infectious diseases like ehrlichiosis, hepatozoonosis or babesiosis. Co-infections with these parasites may also occur. Immune-mediated diseases like polyarthritis, hemolytic anemia or systemic lupus erythematosus, skin diseases like demodicosis or dermatophytosis, endocrine disorders and neoplasias like myelo- and lymphoproliferative diseases can also cause similar clinical manifestations (SOLANO-GALLEGO et al., 2011; KRAWCZAK et al., 2014).

In addition to clinical findings, laboratory abnormalities detectable by routine hematology, clinical chemistry or urinalysis may further increase the clinical suspicion of canine leishmaniasis. Severe CVL is associated with changes in hematological parameters such as severe anemia and leukopenia, associated with lymphopenia, eosinopenia and monocytopenia (TAVARES VERAS et al., 2014). Regarding to biochemical analytes that may be altered in leishmaniotic dogs, there are enzymes of 
hepatobiliary or pancreatic damage that may increase in case of pyogranulomatous infiltrates affecting these organs (SOLANO-GALLEGO et al., 2009; PALTRINIERI et al., 2010), muscular enzymes, including LDH (lactate dehydrogenase) and CK (creatine kinase), that may increase with musculoskeletal lesion (VAMVAKIDIS et al., 2000).

Also, the systemic immune complex disease that characterizes leishmaniasis induces the deposition of circulating immune complexes at the glomerular level. This induces a series of inflammatory glomerular changes detectable histologically and ultramicroscopically (ARESU et al., 2013; KOUTINAS; KOUTINAS, 2014; RIGO et al., 2013; ZATELLI et al., 2003) that are primarily responsible for a proteinuric nephropathy (KOUTINAS; KOUTINAS, 2014). The evolution of this condition, as for any other protein-losing nephropathy, is represented by the development of a chronic kidney disease due to a series of factors that include progressive glomerulosclerosis, renal hypertension, overload of protein reabsorption in tubular cells, with subsequent tubulointerstitial nephritis (ARESU et al., 2013; KOUTINAS; KOUTINAS, 2014), associated with the elevation of glomerular filtration rate, and serum creatine and urea (KOUTINAS; KOUTINAS, 2014).

\subsubsection{Laboratory diagnosis}

Due to the rather variable clinical presentation of leishmaniasis, any clinical suspicion of disease should be confirmed in the laboratory. These tests are either based on direct tests, that identify the parasite, or indirect test, that evaluates the host immune response on serology.

\subsection{Parasitological methods}

Parasites in clinical samples can be demonstrated either directly or after multiplication in vitro culture (CASTAGNARO et al., 2007; SOLANO-GALLEGO et al., 2011; TAVARES VERAS et al., 2014). Optical microscopic examination of Romanovsky-stained smears (conventional cytology) prepared from bone marrow, lymph node, spleen and skin lesions aspirates is a classical method with high specificity but low sensitivity, ranging from 30 to $60 \%$, since the direct parasite identification may be limited, especially in mildly and asymptomatic dogs that have low 
parasitic load, producing false negative results (GOMES et al., 2008; MILES et al., 1999; BARROUIN-MELO et al., 2004; REIS et al., 2006a).

Examination of histological samples taken from multiple tissues is also of use. The histopathological picture, characterized by widespread plasmacytic, lymphocytic, or histiocytic inflammation, most severe in spleen, liver, lymph nodes, bone marrow, however is not specific for leishmaniasis (SARIDOMICHELAKIS, 2009; TAVARES VERAS et al., 2014). Only the visualization of intrahistiocytic amastigote stage, described as round to oval structures, 2-4 $\mu \mathrm{m}$ in diameter with a rod-shaped kinetoplast that is anecdotally reported to be oriented perpendicular to the nucleus and occasionally within other leukocytes, endothelial cells, fibroblasts or neoplastic cells, can confirm the diagnosis (KEGLER et al., 2013; FERRO et al., 2013; KOUTINAS; KOUTINAS, 2014). Mesangioproliferative or membranoproliferative glomerulonephritis and interstitial nephritis are the most common renal manifestations of CVL (COSTA et al., 2010; ARESU et al., 2013). Others lesions include: perivascular, perifollicular or interstitial, multifocal to diffuse, superficial and deep pyogranulomatous to granulomatous to lymphoplasmacytic dermatitis; lymphoplasmacytic or granulomatous myocarditis (especially in the right atrium), myocardial necrosis and increased interstitial collagen; atrophic myositis of masticatory muscles and ocular inflammation in conjunctiva, limbus, ciliary body, iris, cornea and sclera (ROSA et al., 2014; SARIDOMICHELAKIS; KOUTINAS et al., 2014; COLOMBO et al., 2016). Rare reports of meningoencephalitis, vasculitis, myelitis in the central nervous system were done (MÁRQUEZ et al., 2013).

As the number of amastigotes in tissue samples is often very low, diagnosis can be difficult. Thus, the sensitivity of conventional cytology and histopathology can be increased by applying immunocytochemistry and immunohistochemistry, respectively, using specific antibodies to detect the presence of Leishmania in tissue samples (FERRER et al., 1988; SELLS; BURTON, 1981).

Another method that can identify the parasite in tissues is the culturing of tissue fragments or aspirates, preferably in a biphasic medium, allowing the transformation of amastigotes to promastigotes and subsequent multiplication of the latter, which enhances the chances of parasite detection in clinical samples. This parasitological diagnostic method offers high specificity allowing isolation and characterization of parasites, as well as determination of which species and/or variants are circulating in endemic areas (DE ALMEIDA, et al., 2011). On the other hand, many factors can 
influence parasite growth, as the type of culture medium, the length of the incubation period, the amount of sample inoculated in a given amount of medium and the number and type of samples taken (GRADONI, 2002; MATHIS; DELPAZES, 1995). Additionally, this process may be impaired due to parasite death or contamination and may take up to 4 weeks of observation for definitive diagnosis, being a technique restricted to specialized laboratories (ALVAR et al., 2004; PALTRINIERI et al., 2010; DE ALMEIDA, et al., 2011; SOLANO-GALLEGO et al., 2011).

Recently, the use of PCR for parasite detection has gained much attention. Various PCR-based protocols have been developed for the detection of parasite's DNA and CVL diagnosis (TAVARES VERAS et al., 2014). However, the methods used may vary in several parameters, such as fluorophores, probes, target regions and tissue used for detection of target DNA, making it difficult to do a comparative analysis between the different protocols. It is known that the sensitivity and specificity of PCR for detection of Leishmania spp. depends on many factors such as the physicochemical conditions of the reaction, the concentration and nature of the DNA sample, the probes, and oligonucleotide primers selected for the target region (LAUCHAUD et al., 2001; LACHAUD et al., 2002; BASTIEN; PROCOP; REISCHL, 2008). The protocols standardization based on changes in previous parameters is the key step to increased sensitivity, specificity and reproducibility of the tests. The PCR protocol sensitivity is also affected by the type of tissue used in the detection of Leishmania spp. DNA. A wide variety of clinical samples can be used such as blood, lymph node, bone marrow, conjunctiva, skin and spleen. The sensitivity tends to vary, since the parasitic load is not equally distributed in all tissues (SOLANO-GALLEGO et al., 2001; FISA et al., 2001; FRANCINO et al., 2006; MAIA et al., 2009; GALLETTI et la., 2011; SOLCÀ et al., 2014). However, studies have shown that PCR can detect the presence of Leishmania DNA in a similar way, even in different tissues as demonstrated by Manna et al. (2004) in a study using 56 dogs naturally infected with $L$. infantum, which evaluated samples from LN, skin and blood by conventional PCR (cPCR) obtaining positivity values of $99 \%, 95 \%$ and $94 \%$, respectively. The selection of target region in the parasite genome is important because the variation in the number of copies, depending on the region, influences the sensitivity for detecting the parasite's DNA and for quantification of parasite load. The highly conserved and repetitive regions are the most commonly employed, such as the gene for subunit ribosomal RNA (rRNA) or minicircle kinetoplast DNA (kDNA) (REALE et al., 1999; SUNDAR; RAI, 2002; 
ANTINORI et al., 2007; MIRO et al., 2008; BASTIEN, PROCOP, REISCHL 2008), that has 40-200 copies per cell, while the kDNA minicircles have about 10000 copies distributed among 10 different classes of sequences. Using this as a target region confers high sensitivity to PCR (LACHAUD et al., 2002). The use of Real-Time PCR for quantification of leishmania has been reported (BRETAGNE et al., 2001; SCHULZ et al., 2003). For quantification of the parasitic load it is recommended to normalize the amount of parasite gene amplification in relation to a constitutive gene derived from the host genome in order to correct distortions caused by errors related to the DNA used in the PCR reaction (BASTIEN, PROCOP, REISCHL 2008).

\subsection{Serological methods}

Serological tests are based on the presence of specific humoral immune responses against the pathogen or purified fraction or recombinant proteins of the pathogen. These tests allow detection of immunoglobulin (lgG) levels, thus becoming an essential tool for the diagnosis of CVL. Because of the ease of serum sampling and testing, serological methods are widely used for clinical as well as epidemiological purposes (FERRER, 1999).

A wide variety of serological methods are available for CVL diagnosis, presenting variations in sensitivity and specificity. The performance of these diagnostic techniques varies depending on the type of antigen used (whole killed parasites, total soluble antigen or purified natural or recombinant Leishmania antigens) and the detection of anti-Leishmania antibody system.

Enzyme-linked immunosorbent assay (ELISA) and indirect immunofluorescence antibody test were employed for the diagnosis of CVL. More recently, serological methods based rapid tests have been developed using a purified fraction of the parasite or a specific purified recombinant protein, such as rK39 or a chimeric protein as rK28 (rK9 + rK26 + rK39). Despite the practicality and simplicity of serological tests, they revealed a relatively high sensitivity (76.9-92.8\%) and specificity (89.5-99.9\%) (El HARITH et al., 1989; MANCIANTI et al., 1995; RACHAMIM et al., 1991; VERCAMMEN et al., 1997). Thus, the results of such tests should be evaluated carefully, always associated with epidemiological history and clinical state of the animal (DA SILVA et al., 2006), especially in the early stages of the disease. In addition, since titers of anti-Leishmania antibodies remain detectable for long periods, serological 
tests are not a good alternative for assessing healing or monitoring dogs after treatment (FERRER et al., 1995). Efforts have been made to improve the efficacy of rapid tests by developing more sensitive and specific method that could be used in mass screening for the diagnosis of CVL (TAVARES VERAS et al., 2014).

The introduction of commercial vaccines against CVL in Brazil and Europe has raised concerns regarding the use of serological testing for the diagnosis of this important zoonotic disease. The administration of a vaccine may elicit antibody production that could be detected by standard serological diagnostic techniques. This may not allow differentiating between infected and vaccinated animals (SOLANOGALLEGO et al., 2017). Since, there is no sensitive test to discriminate between antibodies to vaccination and to natural infection with $L$. infantum, the use of quantitative serology as the sole diagnostic technique for the detection of $C V L$ in vaccinated dogs is not recommended. Therefore, additional diagnostic techniques based on observation of the inflammatory response in the lesion by cytology or histology, and detection of the parasite or its DNA by PCR or cytology, should be employed in vaccinated dogs (TAVARES VERAS et al., 2014). It is essential to know precise details of the vaccination history of evaluated dogs in order to make a correct interpretation of the serological test employed. All the evaluated information, including history, clinical signs, results of general tests such as complete blood count, biochemistry profile, and urinalysis, and those of specific diagnostic tests such as cytology, histology, quantitative serology, and PCR, should be combined for a comprehensive assessment (SOLANO-GALLEGO et al., 2017).

Currently in Brazil, the diagnosis of CVL is carried out following the protocol recommended by the Ministry of Health, which determined a dualpath platform (colloidal gold-based immunochromatography assay; DPP1 CVL rapid test, BioManguinhos Institute, Fiocruz, Brazil), which uses a recombinant $K 28$ protein of $L$. infantum as antigen, and an indirect ELISA (with antigens of L. major-like promastigote forms; BioManguinhos Institute), for screening and confirmation, respectively. According to this protocol, only positive samples in the first test should be analyzed by ELISA (COURA-VITAL et al., 2011; TAVARES VERAS et al., 2014). Methods of direct detection of the parasite are preferably employed in non-endemic areas, including for the confirmation of the first autochthonous case in a particular municipality (TAVARES VERAS et al., 2014). 
Visceral leishmaniasis is a serious public health problem of great medical and veterinary importance. Dogs are considered the main urban and peri-urban domestic reservoir for this Leishmania. Control strategies include performing accurate and early diagnosis of CVL to identify infected animals, which requires more specific confirmatory tests that can be advantageous to diagnose inconclusive cases, and also improving the knowledge of the factors involved in the parasite-host interaction that may influence the ecology and epidemiology of the disease. 


\section{GENERAL OBJECTIVE}

The main goal of this thesis was to assess new diagnosis methods and host-parasite interaction in the context of different eco-epidemiological scenarios of canine visceral leishmaniasis in São Paulo (SP) state, Brazil.

\subsection{SPECIFIC OBJECTIVES}

- Evaluate the diagnostic efficacy of a series of cytopathological techniques compared to gold standard techniques.

- Evaluate the histopathological lesions, parasite load and cytokine profile by immunohistochemistry in popliteal lymph nodes of dogs naturally infected with Leishmania infantum, from different municipalities of SP state, Brazil.

- Analyze the distribution and the association of a specific genetic marker of $L$. infantum population from SP state with the clinical status and parasite load in popliteal lymph node tissues from dogs naturally infected. 


\section{EVALUATION OF CYTOPATHOLOGICAL TECHNIQUES FOR THE DIAGNOSIS OF CANINE VISCERAL LEISHMANIASIS IN LYMPH NODE SAMPLES}

\subsection{ABSTRACT}

The identification of the parasite in cytological smears of lymph node aspirates is a widely applied technique for the direct diagnosis of Leishmania spp. infection, especially in endemic areas. Although extremely specific, this method presents limited sensitivity, and enhancing strategies is highly desirable. This study aimed to evaluate the efficacy of conventional smear cytology (SC), liquid-based cytology (LBC), cell block (CB) stained with hematoxylin and eosin (H\&E) and immunocytochemistry (ICC), and formalin-fixed paraffin-embedded tissue immunohistochemistry (FFPE-IHC) compared to gold standard techniques (serology and polymerase chain reaction) for the diagnosis of canine visceral leishmaniasis (CVL) in lymphoid tissue. The use of a preservative medium and centrifugation for cytological samples reduced the number of unsatisfactory artifacts/ backgrounds. Moreover, LBC allowed an excellent cellular preservation and the application of ancillary techniques, such as CB and ICC. SC was the most accurate morphological diagnostic method (45.0\%). CB-ICC alone or associated with SC demonstrated significantly higher sensitivity $(70.00 \%$ and $72.00 \%$, respectively) when compared to the SC alone (34.00\%). CB-ICC was found to be more effective in the detection of infected animals with mild clinical signs, similar to FFPEIHC. The specificity and positive predictive value were similar among all methods. Finally, the detection limit for CB-ICC and SC+CB-ICC was identical (18.46 amastigotes $/ \mathrm{mm}^{2}$ ). Our study suggests that CB-ICC is a promising tool to improve the cytopathological diagnosis of CVL and may be applied in routine epidemiological screening.

Key words: Liquid based cytology, cell block, smear cytology, immunohistochemistry, immunocytochemistry, Leishmania, dog. 


\subsection{INTRODUCTION}

Zoonotic visceral leishmaniasis, caused by the protozoan Leishmania infantum, is an important public health issue in the Mediterranean basin, Central and South America, and parts of Asia due to the large number of cases and its clinical severity. Dogs (Canis lupus familiaris) are considered the main domestic reservoir of the parasite in urban and peri-urban areas, and collaborated in the epidemiological cycle of human transmission, since an increase in canine visceral leishmaniasis (CVL) cases usually precedes human infection (Alvar et al., 2012).

The diagnosis of CVL often demands an integrated approach due to wide clinical spectrum and unspecific clinicopathological abnormalities (Solano-Gallego et al., 2009). Classical laboratorial methods for diagnosis of CVL include direct parasitological identification, serological and molecular assays (Tavares Veras et al., 2014). Direct microscopic detection of the parasite in air-dried stained smears from the lymph nodes, spleen and bone marrow aspirate tissues have high specificity, which allows the confirmation of Leishmania spp. infection. Also, in vaccinated dogs, the application of direct diagnostic methodologies is also highly recommended, since no sensitive test to discriminate between antibodies due to vaccination or to $L$. infantum natural infection are described (Solano-Gallego et al., 2017). However, the sensitivity of the conventional smear cytology (SC) is generally less than $30 \%$ due to the limited parasite identification, especially in those dogs with mildly symptomatic and asymptomatic, that presented low parasitic load, which could be implicate in false negative results (Barrouin-Melo et al., 2004; Reis et al., 2006; Gomes et al., 2008). The lymph nodes are a frequent site of infection by the parasite, both in symptomatic and asymptomatic dogs and fine needle aspiration is easier and safer to perform in nodes than in bone marrow tissues (Lima et al., 2004; Saridomichelakis et al., 2005).

In the last 10 years, several new technologies have been introduced in human medicine, attempting to reduce the occurrence of false-negative results in cytology due to sampling, screening, and interpretation problems (Gibb and Martens, 2011). Techniques that applied a preservative fluid medium, such as liquid-based cytology (LBC), for the slide preparation, producing thin layers of immediately-fixed cell smears, have been developed to overcome these limitations (Pawar et al., 2014). Even so, LBC have largely replaced conventional cytological preparations for women cervical samples worldwide (Kavatkar et al., 2008). Moreover, this method allows samples to 
be used for ancillary techniques, such as cell block (CB) and immunocytochemistry (ICC) (Bhatia et al., 2008; Kavatkar et al., 2008; Khan et al., 2012). The CB technique enables the concentration of the cells in suspension, and the resulting pellet is processed to form a paraffin block, which improves diagnostic accuracy and increases the cellular yield (Khan et al., 2012). From the CBs, it is also possible to obtain several paraffin-embedded samples sections for histopathology, multiple immunostainings and molecular studies (Bhatia et al., 2008).

Despite the great importance of cytological diagnosis for clinical practice (Solano-Gallego et al., 2011) and epidemiological monitoring (Ciaravolo et al., 2015) of CVL, few reports of $L B C, C B$, and ICC can be found in veterinary medicine (Fernandes et al., 2016; Menezes et al., 2016). In this context, the present study aimed to apply these techniques in aspirates samples from lymph node of dogs with CVL and compare the performance with conventional SC and histopathology.

\subsection{MATERIALS AND METHODS}

A sectional study with a convenience sample of 60 dogs aged 8 months or older, which included 50 dogs with leishmaniasis and 10 as negative controls was carried out between 2015 and 2016. The diagnosis of CVL was based on clinical signs (enlargement of lymph nodes, splenomegaly, hepatomegaly, poor body condition, onychogryphosis, and skin lesions), serology by immunochromatographic test (DPP_ Bio-Manguinhos, Brazil), enzyme-linked immunosorbent assay (EIE - BioManguinhos, Brazil) and polymerase chain reaction (PCR). This PCR amplifies a segment with $145 \mathrm{pb}$ of a variable region of the $L$. donovani complex minicircle kDNA (le Fichoux et al., 1999; Lachaud et al., 2002), using a specifically set of primers, RV1 (5'-CTTTTCTGGTCCCGCGGGTAGG-3') and RV2 CCACCTGGCCTATTTTACACCA-3'). L. infantum is the only species from this complex that circulates in Brazil, as far we known. DNA molecules were extracted by QIAamp DNA Mini Kit (Qiagen, Hilden, Germany) from lymph node tissue, according to the manufacturer's instructions. To determine the success of DNA extraction control protocol and check for PCR inhibitors, all canine samples were submitted to the amplification of a 911-bp segment of canine 3-phosphate dehydrogenase, with primers (5'-AGG CTG AGA ACG GGA AAC TT-3' and 5'-ATT AAG TTG GGG CAG GGA CT3') (Kullberg et al., 2006). PCR reactions were performed with Go Taq Green Master 
Mix (Promega, WI, USA), 50 pmol of each primer and 5 ul of DNA in a final volume of 25 ul. The amplification conditions included an initial step of $95^{\circ} \mathrm{C}$ for $5 \mathrm{~min} ; 30$ cycles of $30 \mathrm{~s}$ at $95^{\circ} \mathrm{C}, 30 \mathrm{~s}$ at $60^{\circ} \mathrm{C}, 30 \mathrm{~s}$ at $72^{\circ}$, and a final step of $5 \mathrm{~min}$ at $72^{\circ} \mathrm{C}$ in a thermocycler (Touchgene Gradiente, Techne, USA). PCR products were electrophoresed in $2 \%$ agarose gel, stained with GelRed (Biotium, CA, USA) and visualized under ultraviolet (UV) illumination (Uvitec, Cambridge, UK) (Motoie et al., 2013).

Leishmania-infected dogs $(n=50)$ were originally from four $C V L$ endemic municipalities of São Paulo State, Brazil. According to the Staging of Canine Leishmaniasis Working Group (Paltrinieri et al., 2010; Roura et al., 2013), 4/50 (8.0\%) were classified in stage $B, 39 / 50(78.0 \%)$ were in stage $C$, and $7 / 50$ (14.0\%) were in stage $D$ of the disease. Negative samples $(n=10)$ were obtained from 3 veterinary hospitals in São Paulo, SP, Brazil, an area with no records of autochthonous cases of leishmaniasis at that time. These animals were diagnosed with multicentric lymphoma and enlarged lymph nodes and were negative for CVL by serological and molecular tests. This study was approved by the Ethics Committee on Animal Experimentation of the Instituto Adolfo Lutz (CEUA n. 01/2016) and School of Veterinary Medicine and Animal Science of University of São Paulo (CEUA nº. 4079280115).

Cytological samples were collected from popliteal lymph nodes by fine needle aspiration biopsy, one for conventional air-dried smear (SC) and another one, from the same lymph node, for the preparation of LBC smear and CB. The sample was flushed into a conic tube with preservative fluid (Becton Dickinson, TriPath Imaging Burlington, NC, USA) until the liquid acquired some turbidity and the vial were kept refrigerated for up to seven days for analysis. LBC was performed as described in the previous report (Fernandes et al., 2016), and Papanicolau stained smears were obtained using the automated method (Surepath ${ }^{\mathrm{TM}}$, Becton Dickinson, TriPath Imaging, Burlington, NC, USA). The residual sample from LBC preparation $(400 \mu \mathrm{L})$ was centrifuged $(2000 \times \mathrm{g}$, 15 minutes) and the resulting pellet was fixed with $200 \mu \mathrm{L}$ of Bouin solution (formalin $40 \%$, glacial acetic acid $100 \%$ and 2,4,6-Trinitrophenol 1,3\%). Then, cells were centrifuged (2000×g, $15 \mathrm{~min}$ ) again, and the pellets were placed in a cassette and stored in $10 \%$ formalin-buffered solution for up to 6 hours. The cells were submitted to histological routine procedure and embedded in paraffin wax. Three $\mu \mathrm{m}$-thick paraffin sections were obtained for hematoxylin-eosin (H\&E) stain and immunocytochemistry (ICC) analysis. 
According to recommendations of the Brazilian Program for Control of Leishmaniasis (Brasil, 2006) and AVMA Guidelines for the Euthanasia of Animals (Leary et al., 2013), positive animals were anesthetized with sodium thiopental (25 $\mathrm{mg} / \mathrm{kg}$ ). Euthanasia was performed by $19.1 \%$ potassium chloride intravenous injection. A fragment of $2 \times 2 \times 1 \mathrm{~cm}$ of the sampled popliteal lymph nodes was collected into $10 \%$ formalin-buffered solution. Nodal tissues were submitted to histological routine procedure and 4- $\mu \mathrm{m}$ slides were performed for histopathological (H\&E) and immunohistochemical (IHC) analysis.

Unstained slides of both specimens from CB and formalin-fixed paraffinembedded (FFPE) lymph nodes samples were deparaffinized and rehydrated for IHC technique as described previously (Guerra et al., 2016). Briefly, antigen retrieval was performed in a pressure cooker for $3 \mathrm{~min}$, at $120^{\circ} \mathrm{C}$, with citrate buffer ( $10 \mathrm{mM} \mathrm{pH} \mathrm{6.0)}$. Endogenous peroxidases were quenched with $6 \%$ hydrogen peroxide for a minimum of 20 minutes. Slides were incubated with a primary antibody anti-Leishmania (mouse polyclonal, 1:2000) (LIM 50 - Faculdade de Medicina da Universidade de São Paulo) diluted in phosphate-buffered saline $(\mathrm{pH} 7,4), 1 \%$ of bovine serum albumin and $0.1 \%$ of Na3N, for 30 minutes at $37{ }^{\circ} \mathrm{C}$ and overnight at $4{ }^{\circ} \mathrm{C}$ in a humid chamber (Guerra et al., 2016). Picture Max Kit ${ }^{\mathrm{TM}}$ (Life Technologies, Carlsbad, CA, USA) secondary peroxidase short polymer system was carried out for 30 minutes at $37^{\circ} \mathrm{C}$ for signal amplification. Samples were revealed with 3, 3'-diaminobenzidine (Sigma, MO, USA) for 5 minutes at $37^{\circ} \mathrm{C}$. Then, slides were counterstained with Harris' hematoxylin, followed by dehydration and slide mounting with synthetic resin (Merck, NJ, USA).

The slides (SC, LBC, and CB-H\&E) were evaluated for cellular distribution and aggregation, clarity/resolution of cells, cytoplasm and nuclear cellular staining characteristics and the presence of unsatisfactory artifacts or background. Specimens were considered unsatisfactory when less than 10 cells per field or blood cell aggregates were visualized. Amastigotes appear as round or oval bodies measuring 1 to $3 \mu \mathrm{m}$ in length, depending on the technique, and are found free or intracellular in monocytes and macrophages. Parasite density was measured in formalin-fixed paraffin-embedded lymph nodes combined with immunohistochemistry (FFPE-IHC) by counting amastigotes in 5 random fields in a calibrated graticule measuring 0.0625 $\mathrm{mm} 2$ at a magnification of $400 \mathrm{x}$, to calculate the parasitic load cut-off for the visual detection in cytology techniques. 
Categorical data were analyzed by the chi-squared and Fisher's exact tests as appropriate. Data were analyzed using the R software (www.r-porject.org). Specificity, sensitivity, negative predictive values (NPV), positive predictive values (PPV) and accuracy were calculated in a $2 \times 2$ contingency table. A Cohen Kappa contingency coefficient was also used to determine consistency between the methods. Receiver operating characteristic (ROC) curve analysis was used to assess the performance and the limit of detection (number of amastigotes $/ \mathrm{mm}^{2}$ ) for each test, expressed as sensitivity, specificity, and an overall parameter-Youden index. A P value of $<0.05$ was considered statistically significant.

\subsection{RESULTS}

The present study included 60 dogs, 50 naturally infected with L. infatum and 10 uninfected according the serologic and molecular assays. Regarding the quality assessment, $13.33 \%$ (8/60) of samples were unsatisfactory by SC, due to low cellular density and excessive blood contamination. The suitability of the specimen was higher in LBC and CB, both with $4.77 \%$ (3/60) of unsatisfactory samples, but with no statistical significance regarding SC $(P=0.206)$.

$\mathrm{SC}$ is a standard method for cytopathological diagnosis of Leishmania infection in samples obtained by fine needle aspiration, as shown in Figure 1A. In LBC stained with Papanicolaou, red blood cells were often hemolyzed and all others histological cell types were excellently preserved. Also, the background was clearer than that observed in SC, and rare cell superposition and aggregates were noticed. However, there was moderate cell shrinkage and a poor cytoplasm definition, hindering the visualization of amastigotes (Figure 1B). Amastigotes were also smaller than in SC, mainly intracytoplasmatic, with a pale blue staining, that made the detection of parasites more difficult (Figure 1B, inset). The $C B$ slides stained with H\&E demonstrated microscopic aspects similar to the histological tissue. In some cases, it was possible to distinguish nodal microarchitecture, with lymphoid follicles and capillary delineation. Amastigotes appear as slight basophilic intra-cytoplasmic structures (Figure 1C). CB combined with ICC evidenced parasites free or inside the macrophages in a very distinguished brownish color (Figure 1D). 
Regarding morphological diagnostic techniques, SC revealed 28.33\% (17/60) of cases with microscopic structures compatible with amastigotes in macrophages. LBC showed positivity in $16.7 \%(10 / 60)$ of cases, while amastigotes were visible in $18.3 \%(11 / 60)$ of cases in CB-H\&E. However, there was no statistical difference among all 3 cytological techniques $(P>0.05)$. On the other hand, when considering the $\mathrm{IHC}$ methods, $58.3 \%$ (35/60) and $76.7 \%$ (46/60) of samples were positive for Leishmania infection in CB-ICC and FFPE-IHC, respectively, a highly significance proportion compared to SC alone $(P=0.00174 ; P<0.0001)$ (Table 1).

The PPV and specificity were $100.0 \%$ among the five methods, since all uninfected cases were negative by SC, LBC, CB-H\&E, CB-ICC, and FFPE-IHC. The sensitivity of SC (34.0\%) was significantly higher than those of LBC $(20.0 \% ; P=0.038)$ and CB-H\&E (22.0\%; $P=0.047)$. Moreover, despite high NPV (23.3\%) and accuracy $(45.0 \%)$ for SC, these values were not statistically significant when compared to LBC (20.0\%; $P=0.692$, and 33.3\%; $P=0.121$, respectively) and CB-H\&E $(20.4 \% ; P=0.745$ and $35.0 \% ; P=0.194$, respectively). The sensitivity and NPV of the CB-ICC $(70.0 \%$ and $40.0 \%$, respectively) and FFPE-IHC (92.0\% and $71.4 \%$, respectively) showed statistically significant association between these variables $(P=0.0001$ and $P<$ $0.00001)$, while the accuracy (75.0\% and 93.3\%, respectively) between the 2 methods were similar $(P=0.053)$. Further, we compared the diagnostic efficacy of SC and CBICC alone or in combination. The sensitivity, NPV, and accuracy between SC+CB-ICC and SC alone was statistically higher $(P<0.00001, P<0.00001$ and $P=0.0085$, respectively). However, no significant differences in accuracy $(P=0.886)$ or sensitivity $(P=0.876)$ were noticed between the CB-ICC in combination with SC and CB-ICC alone (Table 2).

A slight degree of agreement was observed when the results of serology and PCR were compared with SC (Kappa $=0.1466$, 95\% confidence interval $(\mathrm{Cl}) 0.0448$ to 0.2484$)$, CB-H\&E (Kappa $=0.0859,95 \%$ Cl 0.0171 to 0.1547$)$, and LBC (Kappa = $0.0769,95 \% \mathrm{Cl} 0.0134$ to 0.1404$)$ for Leishmania infection. Additionally, CB-ICC demonstrated a moderate agreement with the serology and PCR (Kappa $=0.437,95 \%$ $\mathrm{Cl} 0.2337$ to 0.6413 ), but still below FFPE-IHC (Kappa $=0.793,95 \% \mathrm{Cl} 0.6015$ to 0.9847) for the identification of Leishmania amastigotes.

Regarding the classification of the clinical stage of visceral leishmaniasis in dogs, none of the cytomorphological methodologies were able to identify animals in clinical stage B. Only 1 case (25\%) of dogs considered "infected", according to the 
Staging of Canine Leishmaniasis Working Group (Paltrinieri et al., 2010; Roura et al., 2013), was diagnosed as positive through FFPE-IHC. For animals in clinical stage $C$, $12 / 39$ (30.8\%) cases were positive in SC, $7 / 39$ (17.9\%) cases in LBC, and 8/39 (20.5\%) cases in CB-H\&E, without statistical differences between the proportions $(P=0.3638)$. In addition, 28/39 (71.8\%) and 38/39 (97.4\%) samples were positive through CB-ICC and FFPE-IHC, respectively, a statistically significant difference $(P=0.00319)$. For severely clinically diseased dogs (stage D), 5/7 (71.4\%) cases confirmed Leishmania infection in SC and $3 / 7(42.9 \%)$ cases were positive by LBC and CB-H\&E $(P=0.6353)$, while $7 / 7(100.0 \%)$ samples were positive by CB-ICC and FFPE-IHC $(P=1.000)$ (Table $3)$.

The detection limit of the methodologies was calculated through ROC curve analysis, considering the amastigote count per square millimeter obtained in FFPEIHC. The ROC curve analysis revealed a cutoff for LBC positive for Leishmania infection at 646.15 amastigotes $/ \mathrm{mm}^{2}$ with a sensitivity of $80.0 \%(95 \% \mathrm{Cl} 44.0$ to $97.5 \%)$ and specificity of $72.0 \%(95 \% \mathrm{Cl} 57.5$ to $83.8 \%)$, an area under the ROC curve of 0.798 , and a $95 \% \mathrm{Cl}$ between $0.674-0.891(P<0.0001)$. For the detection in $\mathrm{SC}$ testing, ROC curve analysis revealed a cutoff at 400 amastigotes $/ \mathrm{mm}^{2}$ with a sensitivity of $88.2 \%(95 \% \mathrm{Cl} 63.6$ to $98.5 \%)$ and a specificity of $67.4 \%$ (95\% $\mathrm{Cl} 51.5$ to $80.9 \%)$, an area under the ROC curve of 0.842 , and a $95 \% \mathrm{Cl}$ between $0.725-0.923(P<0.0001)$. The cutoffs for CB-H\&E, CB-ICC, and SC+CB-ICC through ROC curve analysis were similar, 18.46 amastigotes $/ \mathrm{mm}^{2}$, but the sensitivity and specificity were $100.0 \%(95 \%$ $\mathrm{Cl} 71,5$ to $100.0 \%$ ) and $38.8 \%$ ( $95 \% \mathrm{Cl} 25.2$ to $53.8 \%$ ), $97.1 \%$ (95\% Cl 85.1 to $99.9 \%$ ) and $72.0 \%$ (95\% Cl 50.6 to $87.9 \%$ ), and $97.2 \%$ (95\% Cl 85.5 to $99.9 \%)$ and $75.0 \%$ $(95 \% \mathrm{Cl} 53.3$ to $90.2 \%)$, respectively. The area under the ROC curve was 0.654 with a 95\% $\mathrm{Cl}$ between $0.520-0.722(P=0.0615)$ to $\mathrm{CB}-\mathrm{H} \& \mathrm{E} ; 0.868$ and a $95 \% \mathrm{Cl}$ between $0.756-0.942(P<0.0001)$ to $\mathrm{CB}-\mathrm{ICC}$, and $0.878(95 \% \mathrm{Cl} 0.768$ to 0.948$)$ to SC+CB-ICC $(P<0.0001)$. For the FFPE-IHC, ROC curve analysis revealed a cutoff at 9.23 amastigotes $/ \mathrm{mm}^{2}$ with a sensitivity of $91.3 \%(95 \% \mathrm{Cl} 79.2$ to $97.6 \%)$ and specificity of $100.0 \%$ (95\% Cl 76.8 to $100.0 \%$ ), an area under the ROC curve of 0.986 and a $95 \%$ $\mathrm{Cl}$ between $0.915-1.000(P<0.0001)$. 


\subsection{DISCUSSION}

This study applied cytomorphologic (SC, LBC, and CB-H\&E) and immunological (CB-ICC and FFPE-IHC) techniques in lymphoid samples for leishmaniasis diagnosis. Moreover, it intended to evaluate these methods in comparison with the golden standard methodologies for Leishmania detection (i.e. serological and molecular techniques), assessing sensitivity, specificity, predictive values, and accuracy. To the best of our knowledge, our study is the first to apply LBC and CB in lymph node aspirates to Leishmania detection.

Lymphadenomegaly is a common finding in canine leishmaniasis and it is associated with reactive lymphoid hyperplasia and granulomatous lymphadenitis (Guerra et al., 2016). It is important to notice that no significant difference was found in the sensitivity of cytological smears between lymph nodes and bone marrow aspirates, despite the bone marrow and spleen were described as the body tissues with highest density of Leishmania amastigotes (Saridomichelakis et al., 2005). Also, amastigote count was higher in the lymph nodes in symptomatic dogs compared to bone marrow. Moreover, in the clinical setting, lymph node fine-needle biopsy for cytology is generally easier than bone marrow aspiration, since anesthesia and sedation are unnecessary (Mylonakis et al., 2005; Saridomichelakis et al., 2005).

SC remains a powerful diagnostic tool for Leishmania infection due to its minimal technical requirements, low cost, fast availability of the test results, and high specificity (Noli and Saridomichelakis, 2014). However, the sensitivity of the SC diagnosis depends on the skills and experience of the examiner, the quality of the smear preparation, the presence of interferers, as endogen pigments and blood contamination, the time devoted to the slide screening, the number of fields examined in oil immersion, and the parasitic load in the sample (Saridomichelakis et al., 2005; Noli and Saridomichelakis, 2014). In addition, SC requires additional uncolored fixed samples on glass slides to perform complementary techniques, which are sometimes difficult to obtain, especially if the laboratory is far from the collection site, a common situation within the epidemiological surveillance system for CVL.

LBC is a cytology method applied in gynecologic and non-gynecologic samples from humans and allows easy and rapid fixation of cells in a preservative fluid (Gibb and Martens, 2011). There is only one description of Leishmania detected by this method in a bronchoalveolar fluid cytology from a human patient with visceral 
leishmaniasis using the Surepath ${ }^{\mathrm{TM}}$ method. The amastigotes were smaller than in a conventional cytology, mainly with intracellular forms in macrophages (Gupta et al., 2015), as found in our cases. Due to these morphologic and staining differences among LBC and SC, the cytologists must be alerted and trained before diagnosing LBC, in order to avoid false negative results (Fernandes et al., 2016). LBC enables storage for a long time, up to 1 month at room temperature and 3 months at refrigeration, with easy transportation, good preservation of cellular morphology, and application of ancillary methodologies, such as CB and PCR. Moreover, sample collection is easier than SC, once the slide production is made in the laboratory, automatized, semi-automated or manually, depending on the laboratory demand and structure (Gupta et al., 2001). Also, LBC usually enhances smear quality, with reduction of unsatisfactory results, related to low cell representation, as shown in this study. These advantages are especially interesting in public health scenarios, as endemic areas may be far from reference laboratories and a new sample collection could be challenging. In this way, although LBC exhibited lower sensitivity, specificity, and accuracy than SC, it can be used in association with CB-ICC, combining the advantages of both methods.

CB-H\&E and CB-ICC have been used for diagnosis of CVL previously, in bone marrow (Abrantes et al., 2016; Fernandes et al., 2016) and spleen (Santos et al., 2016) samples, but sensitivity and specificity of techniques was not assessed due to lack of negative samples. Some advantages of these techniques included the permanent storage of paraffin blocks at room temperature and the production of multiple slides used for different histochemical and immunostainings. However, they require a more sophisticated laboratory infrastructure and reagents, which increases the final cost of the exam. CB-H\&E have been described as a robust technique for distinguishing some tissue microarchitecture, since it concentrates the cytology samples by centrifugation and embeds them in paraffin wax (Fernandes et al., 2016; Santos et al., 2016). In this technique, intracellular organisms morphologically consistent with Leishmania spp. amastigotes may be seen in macrophages; however, as occurs in FFPE tissue fragments, definitive identification of the parasite could be hampered by shrinkage of amastigotes during formalin fixation (Saridomichelakis and Koutinas, 2014), resulting in low sensitivity, specificity, and accuracy values. In addition, immunostaining of serial paraffin-sections is commonly applied for a complementary or definitive cytopathological analysis. Compared to morphological methodologies, CB-ICC was 
much more accurate and reliable to diagnose canine leishmaniasis in lymphoid samples, with results similar to FFPE-IHC technique. In both ICC and IHC, amastigotes were colored in brown and very distinguished from the cell cytoplasm.

The ROC curve was used to assess the detection limit and the test's discriminative power through the sensitivity/specificity of each technique. LBC demonstrated the highest cutoff value (646.15 amastigotes $/ \mathrm{mm}^{2}$ ) among all methodologies. The ROC analysis of SC provided a cutoff value of 400 amastigotes $/ \mathrm{mm}^{2}$, while the cutoff for CB-H\&E, CB-ICC, and SC+CB-ICC through ROC curve analysis was similar, 18.46 amastigotes $/ \mathrm{mm}^{2}$, with different sensitivity and specificity values. Then, the effectiveness of all these cytopathological techniques for canine leishmaniasis diagnosis depends on parasite load in the evaluated site (Noli and Saridomichelakis, 2014). SC proved to be the most effective morphological technique tested, but the addition of immunostains, such as ICC and IHC, were shown to be much more sensible for detecting low parasite density cases. However, different from cytopathological techniques, biopsy of lymph nodes for FFPE-IHC requires anesthesia in a hospital environment.

This is also true considering the clinical status, an essential parameter that affects the sensitivity of cytopathology in CVL, since it is also related to the parasite load in the tissue (Saridomichelakis et al., 2005). In dogs with severely clinically diseased status (Stage D), the positivity rate was $71.4 \%$ for SC and $100 \%$ for CB-ICC, whereas for infected animals (Stage B), all cases were negative for SC, LBC, and CBICC, and only one case was identified as positive through FFPE-IHQ (25.0\%). This finding is in agreement with a lower sensitivity of microscopy identification of amastigotes in asymptomatically infected dogs (Lima et al., 2004) and easily justified by their relatively low parasitic burden (Cardoso et al., 1998) similar to the asymptomatic human cases of visceral leishmaniasis (Riera et al., 2004). Also, popliteal lymph nodes are not necessarily the most parasitized tissue in asymptomatic dogs, and other studies with cytological and histological examination of different sites could be conducted, especially in a group with more animals in this clinical stage. A difference in sensitivity of CB-ICC was also observed according to the municipality of sample collection, although this difference was not statically significant, these data corroborate with the hypothesis that this parameter may be dependent on the prevalence and epidemiology of the disease (Leefang et al., 2013). 
In conclusion, the CB preparation associated with immunocytochemistry of fine needle biopsy aspiration of the popliteal lymph node samples represents a practical and useful tool for the refinement of the direct parasitological diagnosis in dogs naturally infected by Leishmania spp. and could be employed for regular epidemiological screening, especially in the algorithm for the diagnosis of the first autochthonous case of CVL in VL control and surveillance program of Brazilian Ministry of Health.

\section{Funding}

This work was supported by Grant Program \#12/51267-4 São Paulo Research Foundation (FAPESP), Brazil; Grant Program for the Study of Neglected and Reemerging Diseases, process MCTI/CNPq/MS-SCTIE-Decit No 40/2012; and Projeto Universal CNPq, Brazil (grant number 459489/2014-3). 
Table 1. Results of different cytological techniques and immunochemistry methods in canine lymph nodes for the detection of Leishmania infantum parasite infection in comparison to serology and molecular diagnostic assays.

\begin{tabular}{|c|c|c|c|}
\hline \multicolumn{2}{|c|}{ Methods } & \multicolumn{2}{|c|}{ Serology + PCR for Leishmania infantum } \\
\hline & & Positive & Negative \\
\hline \multirow[t]{2}{*}{ SC } & Positive & $17(28.33 \%)$ & $0(0.00 \%)$ \\
\hline & Negative & $33(55.00 \%)$ & $10(16.67 \%)$ \\
\hline \multirow[t]{2}{*}{ LBC } & Positive & $10(16.67 \%)$ & $0(0.00 \%)$ \\
\hline & Negative & $40(66.67 \%)$ & $10(16.67 \%)$ \\
\hline \multirow[t]{2}{*}{ CB-H\&E } & Positive & $11(18.33 \%)$ & $0(0.00 \%)$ \\
\hline & Negative & $39(65.00 \%)$ & $10(16.67 \%)$ \\
\hline \multirow[t]{2}{*}{ CB-ICC } & Positive & $35(58.33 \%)$ & $0(0.00 \%)$ \\
\hline & Negative & $15(25.00 \%)$ & $10(16.67 \%)$ \\
\hline \multirow[t]{2}{*}{ FFPE-IHC } & Positive & $46(76.67 \%)$ & $0(0.00 \%)$ \\
\hline & Negative & $4(6.67 \%)$ & $10(16.67 \%)$ \\
\hline
\end{tabular}

SC: smear cytology; LBC: liquid-based cytology; CB-H\&E: cell block histology combined with hematoxylin-eosin; CB-ICC: cell block histology combined with immunocytochemistry; FFPE-IHC: formalin-fixed paraffin-embedded combined with immunohistochemistry. P-value by Fischer's test. 
Table 2. Comparison of diagnostic efficacy for the detection of Leishmania infantum parasite infection among different cytological techniques and immunochemical methods in canine lymph nodes.

\begin{tabular}{|c|c|c|c|c|c|}
\hline Technique & $\begin{array}{c}\text { Sensitivity, } \\
\% \text { (n) } \\
95 \% \mathrm{Cl}\end{array}$ & $\begin{array}{c}\text { Specificity, } \\
\% \text { (n) } \\
95 \% \mathrm{Cl}\end{array}$ & $\begin{array}{c}\text { PPV, \% (n) } \\
95 \% \mathrm{Cl}\end{array}$ & $\begin{array}{c}\text { NPV, \% (n) } \\
95 \% \mathrm{Cl}\end{array}$ & $\begin{array}{c}\text { Accuracy, } \\
\% \text { (n) } \\
95 \% \mathrm{Cl}\end{array}$ \\
\hline SC & $\begin{array}{c}34.00 \% \\
(21.59 \%- \\
48.86 \%)\end{array}$ & $\begin{array}{l}100.00 \% \\
(65.55 \%- \\
100.00 \%)\end{array}$ & $\begin{array}{l}100.00 \% \\
(77.08 \%- \\
100.00 \%)\end{array}$ & $\begin{array}{c}23.26 \% \\
(12.28 \%- \\
38.99 \%)\end{array}$ & $\begin{array}{c}45.00 \% \\
(32.12 \%- \\
58.39 \%)\end{array}$ \\
\hline LBC & $\begin{array}{c}20.00 \% \\
(10.50 \%- \\
34.13 \%)\end{array}$ & $\begin{array}{l}100.00 \% \\
(65.55 \%- \\
100.00 \%)\end{array}$ & $\begin{array}{l}100.00 \% \\
(65.55 \%- \\
100.00 \%)\end{array}$ & $\begin{array}{c}20.00 \% \\
(10.50 \%- \\
34.14 \%)\end{array}$ & $\begin{array}{c}33.33 \% \\
(21.69 \%- \\
46.69 \%)\end{array}$ \\
\hline CB-H\&E & $\begin{array}{c}22.00 \% \\
(11.53 \%- \\
35.96 \%)\end{array}$ & $\begin{array}{l}100.00 \% \\
(65.55 \%- \\
100.00 \%)\end{array}$ & $\begin{array}{l}100.00 \% \\
(67.86 \%- \\
100.00 \%)\end{array}$ & $\begin{array}{c}20.41 \% \\
(18.12 \%- \\
22.90 \%)\end{array}$ & $\begin{array}{c}35.00 \% \\
(23.13 \%- \\
48.40 \%)\end{array}$ \\
\hline CB-ICC & $\begin{array}{c}70.00 \% \\
(55.22 \%- \\
81.71 \%)\end{array}$ & $\begin{array}{l}100.00 \% \\
(65.55 \%- \\
100.00 \%)\end{array}$ & $\begin{array}{l}100.00 \% \\
(87.68 \%- \\
100.00 \%)\end{array}$ & $\begin{array}{c}40.00 \% \\
(21.81 \%- \\
61.11 \%)\end{array}$ & $\begin{array}{c}75.00 \% \\
(62.14 \%- \\
85.28 \%)\end{array}$ \\
\hline FFPE-IHC & $\begin{array}{c}92.00 \% \\
(79.89 \%- \\
97.41 \%)\end{array}$ & $\begin{array}{l}100.00 \% \\
(65.55 \%- \\
100.00 \%)\end{array}$ & $\begin{array}{l}100.00 \% \\
(90.40 \%- \\
100.00 \%)\end{array}$ & $\begin{array}{c}71.43 \% \\
(42.00 \%- \\
90.42 \%)\end{array}$ & $\begin{array}{c}93.33 \% \\
(83.80 \%- \\
98.15 \%)\end{array}$ \\
\hline $\begin{array}{c}\text { SC + CB- } \\
\text { ICC }\end{array}$ & $\begin{array}{c}72.00 \% \\
(57.29 \%- \\
83.33 \%)\end{array}$ & $\begin{array}{l}100.00 \% \\
(65.55 \%- \\
100.00 \%)\end{array}$ & $\begin{array}{l}100.00 \% \\
(87.99 \%- \\
100.00 \%)\end{array}$ & $\begin{array}{c}41.67 \% \\
(22.80 \%- \\
63.06 \%)\end{array}$ & $\begin{array}{c}76.67 \% \\
(63.96 \%- \\
86.62 \%)\end{array}$ \\
\hline
\end{tabular}

SC: conventional smear cytology; LBC: liquid-based cytology; CB-H\&E: cell block histology combined with hematoxylin-eosin; CB-ICC: cell block histology combined with immunocytochemistry; FFPE-IHC: formalin-fixed paraffin-embedded combined with immunohistochemistry; PPV: positive predictive value; NPV: negative predictive value; $\mathrm{Cl}$ : confidence interval. 
Table 3. Results of SC, LBC, CB-ICC, and FFEP-IHQ methods in canine lymph nodes according to the clinical classification stage of leishmaniasis in dogs.

\begin{tabular}{|c|c|c|c|c|}
\hline \multicolumn{2}{|c|}{ Technique } & \multicolumn{3}{|c|}{$\begin{array}{l}\text { Clinical stage classification of leishmaniasis in } \\
\text { dogs }\end{array}$} \\
\hline & & $\begin{array}{c}B(n=4) \\
\text { (Infected) }\end{array}$ & $\begin{array}{l}\text { C (n=39) } \\
\text { (Clinically } \\
\text { diseased) }\end{array}$ & $\begin{array}{c}\text { D (n=7) } \\
\text { (Severely } \\
\text { clinically } \\
\text { diseased) }\end{array}$ \\
\hline \multirow[t]{2}{*}{ SC } & Positive & $0(0.0 \%)$ & $12(30.8 \%)$ & $5(71.4 \%)$ \\
\hline & Negative & $4(100.0 \%)$ & $27(69.2 \%)$ & $2(28.6 \%)$ \\
\hline \multirow[t]{2}{*}{ LBC } & Positive & $0(0.0 \%)$ & $7(17.9 \%)$ & $3(42.9 \%)$ \\
\hline & Negative & $4(100.0 \%)$ & $32(82.1 \%)$ & $4(57.1 \%)$ \\
\hline \multirow[t]{2}{*}{ CB-H\&E } & Positive & $0(0.0 \%)$ & $8(20.5 \%)$ & $3(42.9 \%)$ \\
\hline & Negative & $4(100.0 \%)$ & $31(79.5 \%)$ & $4(57.1 \%)$ \\
\hline \multirow[t]{2}{*}{ CB-ICC } & Positive & $0(0.0 \%)$ & $28(71.8 \%)$ & $7(100.0 \%)$ \\
\hline & Negative & $4(100.0 \%)$ & $11(28.2 \%)$ & $0(0.0 \%)$ \\
\hline \multirow[t]{2}{*}{ FFPE-IHC } & Positive & $1(25.0 \%)$ & $38(97.4 \%)$ & $7(100.0 \%)$ \\
\hline & Negative & $3(75.0 \%)$ & $1(2.6 \%)$ & $0(0.0 \%)$ \\
\hline
\end{tabular}

SC: smear cytology; LBC: liquid-based cytology; CB-H\&E: cell block histology combined with hematoxylin-eosin; CB-ICC: cell block histology combined with immunocytochemistry; FFPE-IHC: formalin-fixed paraffin-embedded combined with immunohistochemistry. 


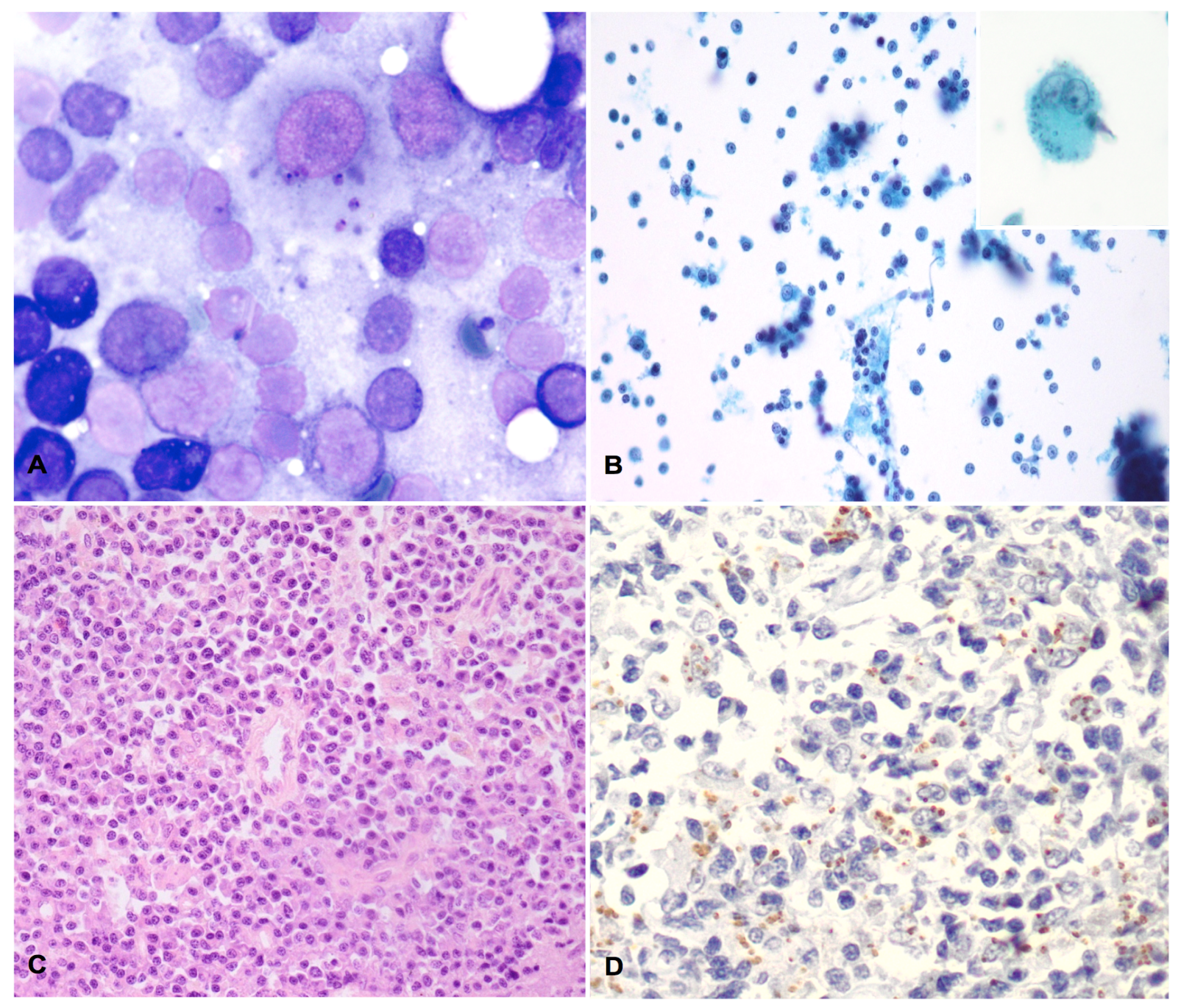

Figure 1. Lymph node fine-needle aspirates from dogs with visceral leishmaniasis. A. Reactive lymphoid population and macrophages with intra-cytoplasmic amastigotes in conventional smear cytology (SC). Original objective 40x. Diff-Quick stain. B. In liquidbased cytology (LBC), a mixed population of small and large lymphocytes, plasma cells and macrophages. Original objective 20x. Inset: amastigotes within macrophages in high-power field. Original objective 40x. Papanicolaou stain. C. Histological sections processed by cell block $(\mathrm{CB})$ technique, evidencing the maintenance of the tissue architecture with some vascular structures. Original objective 10x. Hematoxylin and eosin. D. Amastigote forms of Leishmania spp. (brown) in the cytoplasm of macrophages by immunocytochemistry of the cell block (CB-ICC). Original objective 20x. Counterstaining with hematoxylin. 


\subsection{REFERENCES}

Abrantes TR, Madeira M de F, Silva da, Perié dos SFS, V. Mendes Júnior AA et al. (2016) Identification of canine visceral leishmaniasis in a previously unaffected area by conventional diagnostic tecnhiques and cell-block fixation. Revista do Instituto de Medicina Tropical de São Paulo, 58, 1-5.

Alvar J, Vélez ID, Bern C, Herrero M, Desjeux P et al. (2012) Leishmaniasis Worldwide and Global Estimates of Its Incidence M Kirk, Ed. PLoS ONE, 7, e35671.

Barrouin-Melo SM, Larangeira DF, Trigo J, Aguiar PHP, Dos-Santos WLC et al. (2004) Comparison between splenic and lymph node aspirations as sampling methods for the parasitological detection of Leishmania chagasi infection in dogs. Memórias do Instituto Oswaldo Cruz, 99, 195-197.

Bhatia P, Dey P, Uppal R, Shifa R, Srinivasan R et al. (2008) Cell Blocks from Scraping of Cytology Smear. Acta Cytologica, 52, 329-333.

Brasil - Ministério da Saúde do. (2006) LEISHMANIOSE VISCERAL-Manual de vigilância e controle. Ministério da Saúde, 12, 1 -120.

Cardoso L, Neto F, Sousa JC, Rodrigues M, Cabral M. (1998) Use of a leishmanin skin test in the detection of canine Leishmania-specific cellular immunity. Veterinary Parasitology, 79, 213-220.

Ciaravolo RMC, OliveiraSS, Hiramoto RM, Henriques LF, Taniguch HH, et al. (2015) Classificação epidemiológica dos municípios segundo o programa de vigilância e controle da leishmaniose visceral no estado de São Paulo, dezembro de 2014. Boletim Epidemiológico Paulista, 143, 9-22.

Fernandes NCCCA, Guerra JMM, Réssio RAA, Wasques DGG, Etlinger-Colonelli D et al. (2016) Liquid-based cytology and cell block immunocytochemistry in veterinary medicine: comparison with standard cytology for the evaluation of canine lymphoid samples. Veterinary and Comparative Oncology, 14, 107-116.

le Fichoux Y, Quaranta JF, Aufeuvre JP, Lelievre A, Marty P et al. (1999) Occurrence of Leishmania infantum parasitemia in asymptomatic blood donors living in an area of endemicity in southern France. Journal of clinical microbiology, 37, 1953-7.

Gibb RK, Martens MG. (2011) The impact of liquid-based cytology in decreasing the incidence of cervical cancer. Reviews in obstetrics \& gynecology, 4, S2-S11. 
Gomes YM, Paiva Cavalcanti M, Lira RA, Abath FGC, Alves LC. (2008) Diagnosis of canine visceral leishmaniasis: biotechnological advances. Veterinary journal (London, England: 1997), 175, 45-52.

Guerra J.M., Fernandes N.C.C.A., Kimura L.M., Shirata N.K., Magno J.A., Abrantes M.F., et al. (2016) Avaliação do exame imuno-histoquímico para o diagnóstico de Leishmania spp. em amostras de tecidos caninos. Revista do Instituto Adolfo Lutz, São Paulo;75, 1-10.

Gupta N, Agarwal R, Rajwanshi A. (2015) Liquid-based cytology sample showing leishmaniasis in bronchoalveolar lavage fluid. Cytopathology: official journal of the British Society for Clinical Cytology, 26, 59-60.

Gupta PK, Baloch ZW, Cobbs C, Bibbo M. (2001) Processing Liquid-Based Gynecologic Specimens. Acta Cytologica, 45, 995-998.

Kavatkar AN, Nagwanshi CA, Dabak SM. (2008) Study of a manual method of liquidbased cervical cytology. Indian journal of pathology \& microbiology, 51, 190-4.

Khan S, Omar T, Michelow P. (2012) Effectiveness of the cell block technique in diagnostic cytopathology. Journal of Cytology, 29, 177.

Kullberg M, Nilsson MA, Arnason U, Harley EH, Janke A. (2006) Housekeeping genes for phylogenetic analysis of eutherian relationships. Molecular biology and evolution, 23, 1493-503.

Lachaud L, Chabbert E, Dubessay P, Dereure J, Lamothe J et al. (2002) Value of two PCR methods for the diagnosis of canine visceral leishmaniasis and the detection of asymptomatic carriers. Parasitology, 125, 197-207.

Leary S, Underwood W, Anthony R, Cartner S, Corey D. (2013) AVMA Guidelines for Euthanasia of Animals: 2013 Edition. [Last accessed April 8, 2019]. Avaliable from: https://www.avma.org/KB/Policies/Documents/euthanasia.pdf.

Leeflang MMG, Rutjes AWS, Reitsma JB, Hooft L, Bossuyt PMM. (2013) Variation of a test's sensitivity and specificity with disease prevalence. Canadian Medical Association Journal, 185, E537-E544.

Lima WG, Michalick MSM, Melo MN de, Tafuri WL, Tafuri WL. (2004) Canine visceral leishmaniasis: a histopathological study of lymph nodes. Acta Tropica, 92, 43-53.

Menezes RC, Madeira MF, Ferreira LC, Barbosa Filho CJL, Miranda LHM et al. (2016) Cell-block Immunohistochemistry of Bone Marrow Aspirates: a Novel Tool to Improve the Diagnosis of Leishmania Infection in Dogs. Journal of Comparative Pathology, 154, $157-160$. 
Ministério da Saúde (2006). LEISHMANIOSE VISCERAL - Manual de vigilância e Controle. Departamento de Vigilância Epidemiológica, Secretaria de Vigilância em Saúde, 122.

Motoie G, Ferreira GEM, Cupolillo E, Canavez F, Pereira-Chioccola VL. (2013) Spatial distribution and population genetics of Leishmania infantum genotypes in São Paulo State, Brazil, employing multilocus microsatellite typing directly in dog infected tissues. Infection, genetics and evolution. Journal of molecular epidemiology and evolutionary genetics in infectious diseases, 18, 48-59.

Mylonakis ME, Papaioannou N, Saridomichelakis MN, Koutinas AF, Billinis C et al. (2005) Cytologic patterns of lymphadenopathy in dogs infected with Leishmania infantum. Veterinary clinical pathology, 34, 243-7.

Noli C, Saridomichelakis MN. (2014) An update on the diagnosis and treatment of canine leishmaniosis caused by Leishmania infantum (syn. L. chagasi). The Veterinary Journal, 202, 425-435.

Paltrinieri S, Solano-Gallego L, Fondati A, Lubas G, Gradoni L et al. (2010) Guidelines for diagnosis and clinical classification of leishmaniasis in dogs. Journal of the American Veterinary Medical Association, 236, 1184-1191.

Pawar P, Gadkari R, Swami S, Joshi A. (2014) Comparative study of manual liquidbased cytology (MLBC) technique and direct smear technique (conventional) on fineneedle cytology/fine-needle aspiration cytology samples. Journal of Cytology, 31, 83.

Reis AB, Teixeira-Carvalho A, Vale AM, Marques MJ, Giunchetti RC et al. (2006) Isotype patterns of immunoglobulins: hallmarks for clinical status and tissue parasite density in Brazilian dogs naturally infected by Leishmania (Leishmania) chagasi. Veterinary immunology and immunopathology, 112, 102-16.

Riera C, Fisa R, Udina M, Gállego M, Portus M. (2004) Detection of Leishmania infantum cryptic infection in asymptomatic blood donors living in an endemic area (Eivissa, Balearic Islands, Spain) by different diagnostic methods. Transactions of the Royal Society of Tropical Medicine and Hygiene, 98, 102-10.

Roura X, Fondati A, Lubas G, Gradoni L, Maroli M et al. (2013) Prognosis and monitoring of leishmaniasis in dogs: A working group report. The Veterinary Journal, 198, 43-47.

Santos SO, Fontes JLM, Laranjeira DF, Vassallo J, Barrouin-Melo SM et al. (2016) A minimally invasive approach to spleen histopathology in dogs: A new method for 
follow-up studies of spleen changes in the course of Leishmania infantum infection. Comparative Immunology, Microbiology and Infectious Diseases, 48, 87-92.

Saridomichelakis MN, Koutinas AF. (2014) Cutaneous involvement in canine leishmaniosis due to Leishmania infantum (syn. L. chagasi). Veterinary dermatology, 25, 61-71, e22.

Saridomichelakis MN, Mylonakis MEME, Leontides LSLS, Koutinas AFAF, Billinis C et al. (2005) Evaluation of lymph node and bone marrow cytology in the diagnosis of canine leishmaniasis (Leishmania infantum) in symptomatic and asymptomatic dogs. The American journal of tropical medicine and hygiene, 73, 82-6.

Solano-Gallego L, Cardoso L, Pennisi MG, Petersen C, Bourdeau P et al. (2017) Diagnostic Challenges in the Era of Canine Leishmania infantum Vaccines. Trends in Parasitology, 33, 706-717.

Solano-Gallego L, Miró G, Koutinas A, Cardoso L, Pennisi MG et al. (2011) LeishVet guidelines for the practical management of canine leishmaniosis. Parasites \& vectors, $4,86$.

Solano-Gallego L, Koutinas A, Miró G, Cardoso L, Pennisi MG et al. (2009) Directions for the diagnosis, clinical staging, treatment and prevention of canine leishmaniosis. Veterinary Parasitology, 165, 1-18.

Tavares Veras PS, Moth Fraga DB, Silva Solc M da, Sampaio Guedes CE. (2014) New Advances in the Diagnosis of Canine Visceral Leishmaniasis. In: Leishmaniasis Trends in Epidemiology, Diagnosis and Treatment, InTech. 


\section{CYTOKINE PROFILE AND PARASITE LOAD IN LYMPH NODES OF DOGS \\ NATURALLY INFECTED WITH LEISHMANIA INFANTUM FROM DISTINCT EPIDEMIOLOGICAL SCENARIOS IN SAO PAULO STATE, BRAZIL}

\subsection{ABSTRACT}

In South America, visceral leishmaniasis (VL) is an important zoonotic vector-borne disease and domestic dogs are considered the main urban reservoir of $L$. infantum. Distinct eco-epidemiological scenarios related to the prevalence of the disease, clusters of parasite genotypes and chemotypes of vectors population are described in Brazil, especially in São Paulo (SP) state. In this context, this study aimed to evaluate the histopathological lesions, parasite load and cytokine profile by immunohistochemistry (IHC) in popliteal lymph nodes of dogs naturally infected with Leishmania infantum, from different municipalities of SP state. Eighty-three dogs with VL, 61 from northwest of SP (NWSP) and 22 from southeast of SP (SESP), were clinically classified in stage II, with no concurrent diseases. Subcapsular inflammatory infiltration and histiocytosis were significantly higher in SESP group ( $p=0.0128$; 0.0077 , respectively). Otherwise, dogs from NWSP revealed significantly higher parasite burden $(p=0.0004)$ and IHC scores of IL-1 $(p=0.0275)$ and IL-4 ( $p=0.0327)$ in the popliteal lymph node tissues, which may be associated with the susceptibility and progression of the disease in these animals. Differences in immune response profile associated with higher parasite burden can also contribute to explain the distinct epidemiological patterns of VL in specific geographic regions.

Keywords: Canine visceral leishmaniasis; Histopathology; Immunohistochemistry; Lymphadenopathy; Immune response. 


\subsection{HIGHLIGHTS}

- We evaluated histopathological lesion and cytokine profile in lymph nodes of dogs naturally infected with Leishmania infantum from different epidemiological scenarios.

- Higher parasitic load and lower score of IL-4 and IL-1 $\beta$ can contribute to explain the different eco-epidemiological scenarios of VL in São Paulo state.

- These data improve understanding of the host factors in the canine visceral leishmaniasis.

\subsection{INTRODUCTION}

Zoonotic visceral leishmaniasis (VL), caused by Leishmania infantum, is a severe, often fatal, neglected disease, which represents one of the most relevant and challenging emerging diseases worldwide (Desjeux, 2004; WHO, 2017). Brazil harbors approximately $90 \%$ of human cases detected annually in Latin America (Alvar et al., 2012; WHO, 2017). Domestic dogs have long been implicated as the main peri-urban and urban reservoirs of etiological agent of $V L$ due to its close relationship with humans and its high susceptibility to infection (Alvar et al., 2004; Michel et al., 2011). Hence, the recommendations strategies adopted by the Brazilian government to control the disease include systematic diagnosis and treatment of human cases, control of sandfly vectors (especially Lu. longipalpis), testing and culling of seropositive dogs, and health education initiatives (Brasil, 2006). However, despite these efforts, the disease has spread throughout the country (Brasil, 2013; Brasil, 2015).

Although historically described as a rural disease, mainly in northeast and central-west regions of the country, VL has reached endemic and epidemic proportions in many large Brazilian cities since the 1980s (Werneck, 2008; Reis et al., 2017), representing a serious public health problem (Desjeux, 2004). The Brazilian state of São Paulo (SP), located in the southeastern region, is the most populous and economically developed of the 26 states in Brazil (de Melo and Fortaleza, 2013). From 1999 to $2014,2,539$ autochthonous human cases of VL were reported in SP, with a lethality of $8.59 \%$. Until 2016, the parasite was detected in 135 of the 645 municipalities of the state (São Paulo, 2016). 
Two distinct epidemiological scenarios could be identified in this state. One in northwest of SP (NWSP), where the first autochthonous human cases were reported in Araçatuba in 1999, and since then, several other nearby municipalities have described a moderate to intense transmission of the parasite to humans and canines, besides the presence of the vector (Cardim et al., 2013). And the other, in the southeastern region of SP (SESP), where low prevalence of canine visceral leishmaniasis (CVL) has been detected in municipalities since 2003, sometimes without identification of human cases and vectors (Cardim et al., 2013). Different chemotypes populations of Lu. Longipalpis and genotypes of Leishmania infantum, by multilocus microsatellite typing, were also recognized between NWSP and SESP (Casanova et al., 2015; Motoie et al., 2013); however, no reports concerning the vertebrate hosts in these two epidemiological patterns are described.

CVL shares characteristics with its human counterpart, providing a good model to study the immunopathogenesis of $L$. infantum infections. The clinical outcome of CVL is also the result of a multifactorial and complex interaction among the vector, the virulence of parasite, and the immune response of the host (Baneth et al., 2008; Koutinas and Koutinas, 2014). The latter seems to play a key role, as $L$. infantum induces a mixed Th1 and Th2 response and the control of parasite replication, disease progression, or cure are strictly associated with the balance of these two patterns of immune system reaction in infected dogs (Koutinas and Koutinas, 2014).

Generalized lymphadenopathy, defined as the enlargement of lymph nodes, is one of the major clinical signs on symptomatic dogs with VL. As lymph nodes are the first organs affected after systemic dissemination of the parasite from skin macrophages, it is likely that the immunity observed in lymph nodes may be extremely important in determining the prognosis of the disease. Triggering an effective immune response in this organ may avoid an intense proliferation and consequent dissemination of the parasite into other organs. The early humoral and cellular response of popliteal lymph node is related to the evolution of the infection (Costa et al., 2008; Giunchetti et al., 2008; Pinelli et al., 1994), so it is an important site for the evaluation of immune responses in Leishmania infection.

Thus, the aim of this study was to evaluate the cytokine profile and parasite burden in popliteal lymph nodes in dogs naturally infected with $L$. infantum and with similar clinical status from different municipalities of SP state. Our hypothesis was that animals from distinct geographic regions of SP state showed distinct pattern of 
Leishmania infection due to differences on the hosts immune response, through cellular and cytokine production profile and parasite load in lymphoid samples.

\subsection{MATERIALS AND METHODS}

\subsubsection{Study area}

São Paulo state is located in Southeast region of Brazil, divided into 645 municipalities, with an area of $248,209.4 \mathrm{~km}^{2}$. It is limited to the states of Minas Gerais to the north and northeast, the Paraná to the south, Rio de Janeiro to the east, Mato Grosso do Sul to the west, and the Atlantic Ocean to the southeast. The NWSP group was composed of 61 canine samples from six municipalities located in northwest region of SP and the SESP group was composed of 22 canine samples from four municipalities located in southeast regions of SP (Fig. 1). The sampled municipalities of NSWP and SESP, the geographic coordinates and the number of samples were,

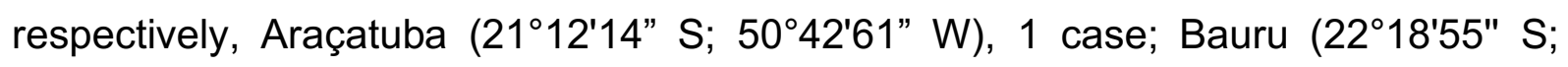

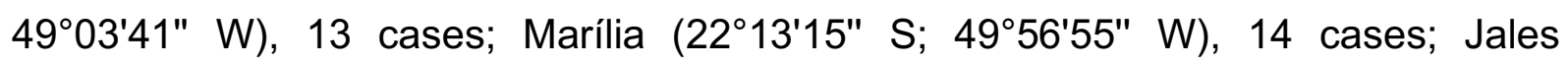
(20¹6'06" S; 50³2'56" W), 2 cases; Votuporanga $\left(20^{\circ} 25^{\prime} 02^{\prime \prime} S 49^{\circ} 58^{\prime \prime} 22^{\prime \prime} \mathrm{W}\right), 21$

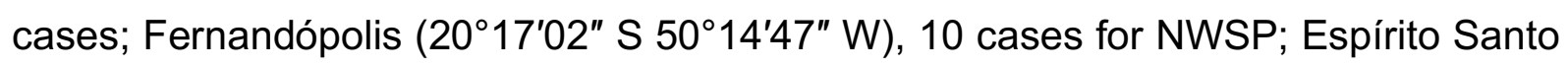

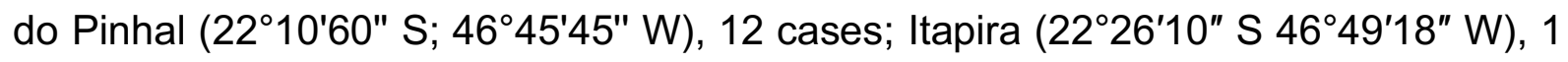

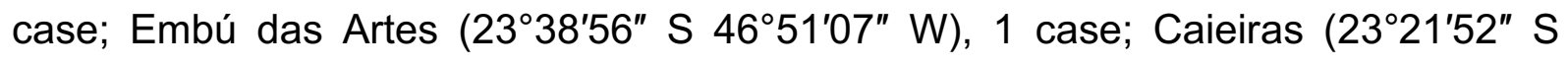
$46^{\circ} 44^{\prime 2} 27^{\prime \prime}$ W), 8 cases for SESP. 


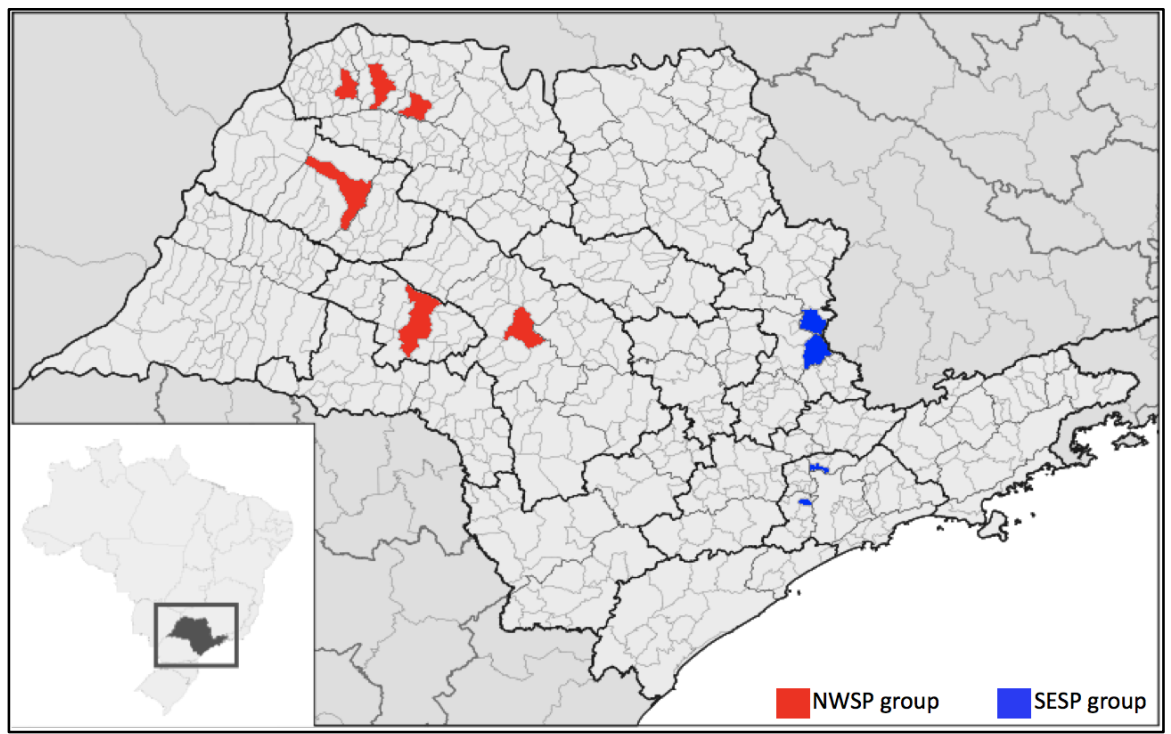

Fig. 1. Municipalities administration division in São Paulo state, Brazil. Distribution of canine samples according geographic localization in two groups: NWSP (red) and SESP (blue).

\subsubsection{Animals}

A cross-sectional study was conducted with a convenience sample of 83 mongrel dogs from the Center of Zoonosis Control of distinct municipalities of SP state. The dogs were submitted to clinical evaluation and collection of biological specimens to perform serological tests, serum biochemical parameters, conventional PCR, histopathological and immunohistochemical analysis to determine the parasite load and the profiles of cytokines, after euthanasia according to the guidelines of the Brazilian Ministry of Health (Brasil, 2006; Brasil, 2009).

The study included animals older than six months of age, regardless of gender, with positive serological results for Leishmania sp. by Immunochromatographic Rapid Test - Dual Path Platform (DPP ${ }^{\circledR}$ ) - BioManguinhos ${ }^{\circledR} /$ FIOCRUZ and Enzyme-Linked Immunosorbent Assay (ELISA) performed by Public Offices, Leishmania infantum infection confirmed by a specific conventional PCR in popliteal lymph nodes samples and animals classified in clinical stage II (moderate disease), graduated according to the LeishVet clinical staging system (Solano-Gallego et al., 2009). Exclusion criteria included the dogs testing positive for other condition, including ehrlichiosis and babesiosis by conventional PCR. 
All procedures were guided by ethical principles established by the National Council for Animal Experiments Control - CONCEA and in accordance with national legislation (No. 11.794, of August 8, 2008 and No. 9605 of February 12, 1998). In addition, all experimental procedures in this study were approved by the Ethics Committee on Animal Experimentation of the Instituto Adolfo Lutz (CEUA nº. 01/2016) and by the School of Veterinary Medicine and Animal Science of University of São Paulo (CEUA n. 4079280115)

\subsubsection{Clinical evaluation}

The animals were submitted to clinical evaluation according to the presence of suggestive clinical signs and symptoms of CVL: cachexia, lymphadenomegaly, hepatosplenomegaly, skin disorders, onychogryphosis and ophthalmologic abnormalities in a standardized clinical form. Furthermore, the dogs were classified according to the LeishVet clinical staging system (Solano-Gallego et al., 2009), after the serum biochemical evaluation. Blood was collected from dogs by jugular venipuncture with a sterile syringe and $2 \mathrm{~mL}$ placed into a tube containing EDTA (ethylenediamine tetraacetic acid) for biomolecular evaluation, and another $5 \mathrm{~mL}$ in a tube containing separation gel, without anticoagulant. It was centrifugated at $5000 \mathrm{rpm}$ for 15 minutes, aliquoted, and stored at $-20^{\circ} \mathrm{C}$ until serological detection of antiLeishmania antibodies and for serum biochemistry evaluation.

\subsubsection{Serological evaluation}

The immunological tests performed were Dual-Path Platform CVL rapid test (TR $\mathrm{DPP}^{\circledR}$ Leishmaniosis Visceral Canina, Bio-Manguinhos, Rio de Janeiro, Brazil), composed of specific recombinant proteins (rK26 and rK39), and enzyme-linked immunosorbent (ELISA EIE ${ }^{\circledR}$ ) (Bio-Manguinhos, FIOCRUZ, Rio de Janeiro, Brazil) (Grimaldi et al., 2012) distributed by the Ministry of Health (Brazil). The procedures were executed as recommended by the manufacturer's instructions at the Parasitology and Mycology Laboratry at Adolfo Lutz Institute, the Central Laboratory of Sao Paulo state, from State Department of Health, São Paulo state. 


\subsubsection{Serum biochemistry evaluation}

The serum dosage was determined by automated chemical analyzer (Liasys, S.R.L. Analyzer Medical System ${ }^{\circledR}$, Assel, Italy) using specific commercial kits, according to the manufacturer's methodology. The levels of urea ( $\mathrm{mg} / \mathrm{dL})$, creatinine (mg/dL), total protein ( $T P$, in $\mathrm{g} / \mathrm{dL})$, albumin (ALB, in $\mathrm{g} / \mathrm{dL})$, glutamate-pyruvate transaminase/alanine aminotransferase (GPT/ALT, in U/L), glutamic-oxaloacetic transaminase/ aspartate aminotransferase (GOT/AST, in U/L) and alkaline phosphatase (AP, in $U / L)$ were determined. The biochemical evaluation results were compared to the reference values for canine species according to Kaneko et al., 1997. Among dogs infected with $L$. infatum, there were no statistical differences among serum biochemical analysis values performed for staging of the disease animals from NWSP and SESP groups (Supplementary material, Table S1). According to these data, all dogs were classified as stage II (moderate disease), since all animals had clinical signs and clinicopathological abnormalities characteristic of CVL at the time of diagnosis. Furthermore, their anti-Leishmania antibody titer ranged low to high levels (Solano-Gallego et al., 2009).

\subsubsection{Euthanasia procedures}

Dogs were contained, sedated and pre-anesthetized with xylazine hydrochloride $(1.0 \mathrm{mg} / \mathrm{kg}$ ) (Vetbrands, Brazil), ketamine hydrochloride $(10 \mathrm{mg} / \mathrm{kg})$ (Agener, Brazil) and diazepam $(1.0 \mathrm{ml} / 10 \mathrm{~kg}$ ) (Hipolabor, Brazil) by intramuscular injection. Then, all animals were euthanized with a lethal dose of $2.5 \%(1.0 \mathrm{ml} / \mathrm{kg})$ Thiopental (intravenous) and $\mathrm{T} 61^{\mathrm{TM}}(0.3 \mathrm{ml} / \mathrm{kg})$ until reach respiratory and subsequent cardiac arrest. Fragments of dogs' popliteal lymph nodes were collected and fixed in buffered formalin at $10 \%$ in order to carry out histological and immunohistochemical studies.

\subsubsection{DNA extraction}

DNA molecules of canine blood samples (200 uL) and two $5 \mu \mathrm{m}$ thick-sections cut from the FFPE popliteal lymph node tissue blocks were extracted by Illustra ${ }^{\mathrm{TM}}$ blood genomic Prep Mini Spin Kit (GE Healthcare Europe GmbH, Glattbrugg Switzerland) 
and ReliaPrep ${ }^{\mathrm{TM}}$ FFPE gDNA Miniprep System (Promega, Madison, WI, USA), respectively, according to the manufacturer's instructions. DNA pellets were dissolved in ultra-pure water. DNA concentrations and purity were determined by the ratio of O.D. at 260 and $280 \mathrm{~nm}$ in a NanoDrop ND1000 spectrophotometer (Thermo Fisher Scientific, Waltham, MA, USA).

\subsubsection{Conventional PCR}

Leishmania infantum infection in canine samples was confirmed by PCR with specific primers RV1 (5'-CTTTTCTGGTCCCGCGGGTAGG-3') and RV2 (5'CCACCTGGCCTATTTTACACCA-3'). This primer set amplifies specifically a 145-bp fragment of the variable region of the minicircle kDNA of $L$. donovani complex (Lachaud et al., 2002; Lachaud et al., 2002a) and as far as we know, the only species from this complex that circulates in Brazil is $L$. infantum. Ehrlichia genus-specific amplification was performed by a Nested-PCR of a partial 122-bp the $16 \mathrm{~S}$ ribosomal DNA (rDNA) with the outer primers EHR-OUT1 (5'CTGGCGGCAAGCYTAACACATGCCAACATCTCACGAC-3') and EHR-OUT2 (5'GCTCGTTGCGGGACTTAACCCAACATCTCACGAC-3') and inner primers GE2F (5'GTTAGTGGCATACGGGTGAAT-3') and

EHRL3-IP2 TCATCTAATAGCGATAAATC-3') (Breitschwerdt et al., 1998). For Babesia spp. detection, PCR based on 16S-like rRNA gene PCR assay with forward (5'GCATTTAGCGATGGACCATTCAAG-3') and

(5'-CCTG

TATTGTTATTTCTTGTCACTACCTC-3') reverse primers were used (Kordick et al., 1999). To check the success of DNA extraction control protocol and the absence of PCR inhibitors, all canine samples were assayed using the gene for the interphotoreceptor retinoid-binding protein (IRBP) amplification based on highly conserved stretches within exon 1 of the canine gene sequence to amplify a 227-bp fragment (nucleotide positions 400-626, GeneBank accession DQ205906). The primers used for IRBP were IRBP-CF-FWD (5'TCCAACACCACCACTGAGATCTGGAC-3') and IRBP-CF-REV (5'GTGAGGAAGAAATCGGACTGGCC-3') (Ferreira et al., 2010). Reactions were carried out with Go Taq Green Master Mix (Promega, Madison, WI, USA) containing 50 pmol of primers and $5 \mathrm{ul}$ of DNA in a final volume of $25 \mathrm{ul}$. The following amplification conditions were used: initial step of $95^{\circ} \mathrm{C}$ for $5 \mathrm{~min} ; 35$ cycles at $94^{\circ} \mathrm{C}$ for $30 \mathrm{~s}, 57^{\circ} \mathrm{C}$ 
(IRBP gene) or $60^{\circ} \mathrm{C}$ (L. Infantum; Erlichia spp; Babesia spp.) for $1 \mathrm{~min}, 72^{\circ} \mathrm{C}$ for $1 \mathrm{~min}$ and then a final extension step at $72^{\circ} \mathrm{C}$ for $5 \mathrm{~min}$ in a thermocycler (Touchgene Gradiente, Techne, USA). PCR products were electrophoresed in $2 \%$ agarose gel, stained with GeIRed (Biotium, CA, USA) and visualized under UV illumination (Uvitec, Cambridge, UK). The negative control used was double-distilled water. DNA from L. infantum strain (MHOM/BR/1972 strain 46LD) and from blood samples of infected dogs with Erlichia canis and Babesia voegli were used as positive controls.

\subsubsection{Histopathology examination}

Popliteal lymph nodes samples immersed in $10 \%$ neutral buffered formalin solution were routinely processed into paraffin wax, according to Guerra et al. (2016). 3- $\mu \mathrm{m}$ tissue sections were stained with Hematoxylin and Eosin (H\&E) and analyzed under light microscopy (CX22, Olympus, Tokyo, Japan) to identify lesions. Histopathological changes were semi quantitatively evaluated and classified as: (0) absence of lesions; (1) discrete; (2) moderate and (3) intense changes, considering capsular thickening, cortical and paracortical hyperplasia, subcapsular inflammatory infiltration, hemosiderosis, congestion and inflammatory cellular components (presence of lymphocytes/ plasma cells, histiocytes, eosinophils, neutrophils and Mott cells).

\subsubsection{Immunohistochemistry (IHC) technique}

Unstained slides were deparaffinized and rehydrated for $\mathrm{IHC}$ as described previously (Guerra et al., 2016). Antigen retrieval was carried out with citrate buffer 10 $\mathrm{mM} \mathrm{pH} 6.0$ or EDTA buffer $1 \mathrm{mM} \mathrm{pH} 9.0$ in a pressure cooker, for $3 \mathrm{~min}$, at $120^{\circ} \mathrm{C}$. Endogenous peroxidase was blocked with $6 \%$ hydrogen peroxide for a minimum of 30 min. Primary antibodies were diluted in bovine serum albumin $1 \%$ and $\mathrm{Na}_{3} \mathrm{~N} 0.1 \%$ on PBS ( $\mathrm{pH} 7.4$ ), followed by overnight incubation (18 hours) at $4{ }^{\circ} \mathrm{C}$. All primary antibodies, manufactures, type, clone, dilution, and antigen retrieval protocol are described in Table 1. Signal amplification with Picture Max Kit ${ }^{\mathrm{TM}}$ (Life Technologies, Carlsbad, CA, USA) secondary peroxidase short polymer system was carried out for 30 minutes at $37^{\circ} \mathrm{C}$. After, samples were incubated with DAB (3,3'-diaminobenzidine; D-5637; Sigma, St. Louis, MO, USA) for $5 \mathrm{~min}$, at $37^{\circ} \mathrm{C}$. The samples were, then, 
counterstained with Harris' Hematoxylin, followed by dehydration and slide mounting with synthetic resin (Merck, NJ, USA).

For each sample, amastigotes were quantified by counting the number of immunolabeled parasites in ten randomized high-power fields considering five fields in the cortical area and five fields in the medullar area of the lymph nodes. A 10x ocular lens was used with a square grid in a 40x objective marking an area field of 0.0625 $\mathrm{mm}^{2}$, allowed the counting of the number of amastigotes per $\mathrm{mm}^{2}$ (Seixas Duarte et al., 2008; Tuon et al., 2009, 2008, 2008a). The intensity and distribution pattern of cytokine and cellular protein expression were evaluated by two independent and blinded observers, by using a semi quantitative method as previously described (Remmele; Stegner, 1987). Briefly, the IHC score was calculated by multiplication of staining intensity (graded as 0: none, 1: weak, 2: moderate ad 3: strong staining) and the percentage of positive staining cells (0: no stained cells, $1:<10 \%$ of the cells, 2 : $11-50 \%$ of the cells, $3: 51-80 \%$ of the cells and $4:>81 \%$ of the cells).

Table 1. Technical specifications of primary antibodies.

\begin{tabular}{|c|c|c|c|c|c|}
\hline Antibody & Reference & Species & $\begin{array}{l}\text { Type, Clone } \\
\text { or Code* }\end{array}$ & Dilution & $\begin{array}{l}\text { Antigen retrieval } \\
\text { protocol }\end{array}$ \\
\hline Anti- & Guerra et al., & Mouse & Pab & $1: 3000$ & CB 10mM pH 6.0 \\
\hline Leishmania ${ }^{a}$ & 2016 & & & & \\
\hline Anti-Pax $5^{b}$ & $\begin{array}{l}\text { Willman et al., } \\
2009\end{array}$ & Mouse & Mab, ZP007 & $1: 400$ & CB $10 \mathrm{mM} \mathrm{pH} 6.0$ \\
\hline Anti-CD3c & $\begin{array}{l}\text { Thalheim et al., } \\
2013\end{array}$ & Rabbit & Pab, A0452 & $1: 200$ & CB 10mM pH 6.0 \\
\hline Anti-IL4d & Garrido, 2015 & Rabbit & Pab, LS-7474 & $1: 400$ & CB $10 \mathrm{mM} \mathrm{pH} 6.0$ \\
\hline Anti-IL $1 \beta^{e}$ & $\begin{array}{l}\text { Lovett et al., } \\
2014\end{array}$ & Rabbit & Pab, ab2105 & $1: 200$ & CB 10mM pH 6.0 \\
\hline Anti-TNF $\alpha^{f}$ & $\begin{array}{l}\text { Roatt et al., } \\
2017\end{array}$ & Goat & Pab, AF1507 & $1: 50$ & TEB $1 \mathrm{mM} \mathrm{pH} 9.0$ \\
\hline Anti-IFN $\gamma^{f}$ & $\begin{array}{l}\text { Chow et al., } \\
2017\end{array}$ & Goat & Pab, AF781 & $1: 50$ & TEB $1 \mathrm{mM} \mathrm{pH} 9.0$ \\
\hline
\end{tabular}


*IL: interleukin; TNF: tumor necrosis factor; IFN: interferon; Mab: monoclonal antibody; Pab: polyclonal antibody; EDTA: Ethylenediamine tetraacetic acid; CB: citrate buffer; TEB: Tris-EDTA buffer. ${ }^{a}$ In house (Laboratory of Medical Investigation-50 of Medicine

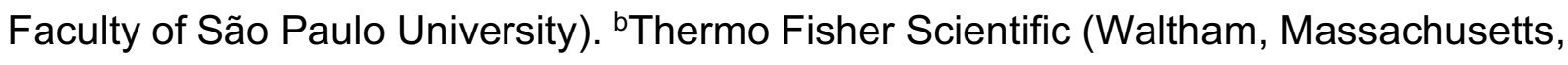
EUA). 'Dako-Agilent (Santa Clara, CA, USA). 'Lifespan Biosciences (Seattle, Washington, EUA). ${ }^{e} A b c a m$ (Cambridge, UK). ${ }^{f} R \& D$ Systems (Minneapolis, MN, EUA)

\subsubsection{Statistical analysis}

Statistical analysis was performed using R statistical software (https://www.rproject.org/) and Graph Pad Prism 4. Pearson's chi-square test and Fisher's exact test were used to evaluate the frequencies distribution of the clinical characteristics in NWSP and SESP groups. The continuous quantitative variables with normal distribution were descriptively presented in mean and standard deviation (SD), while the variables with abnormal distribution were presented in median and interquartile range. The normality of the variables was evaluated by Shapiro-Wilk's test. The differences between the measurements before and after the intervention were analyzed by Student's $t$ test for unpaired samples, in case they presented normal distribution, and by Wilcoxon test for two dependent samples, in case of abnormal distribution. Cytokine and cellular profile evaluations were performed using the nonparametric Mann Whitney U-test. All analyses were two-tailed and pre-specified. Differences were considered to be statistically significant if the probability of a type I error was $<0.05$ ( $P$ value $<0.05)$.

\subsection{RESULTS}

\subsubsection{Clinical characterization of animals}

All animals were mixed-breed dogs and the percentage of male and female animals was very similar between the groups, with 50.8 and $50.0 \%$ of males in NWSP and SESP, respectively; and 49.2 and $50.0 \%$ of females in NWSP and SESP, respectively, with no statically difference $(p=1.000)$. The observed clinical signs were lymphadenomegaly $(60.4$ and $65.0 \% ; p=1.000)$, splenomegaly $(75.8$ and $95.0 \%, p=$ 
0.5353), hepatomegaly (28.1 and 40.0\%; $p=0.7442)$, skin lesions (72.1 and 75\%; $p=$ $0.8225)$, onycogryphosis ( $51.0 \%$ and $25.0 \%$; $p=0.0312)$, emaciation (32.8 and $15.0 \%$; $p=0.1491)$ and opthalmological lesions (19.0 and 20.0\%) in the NWSP and SESP groups, respectively (Fig. 2.) All animals presented at least one typical sign of canine visceral leishmaniasis.

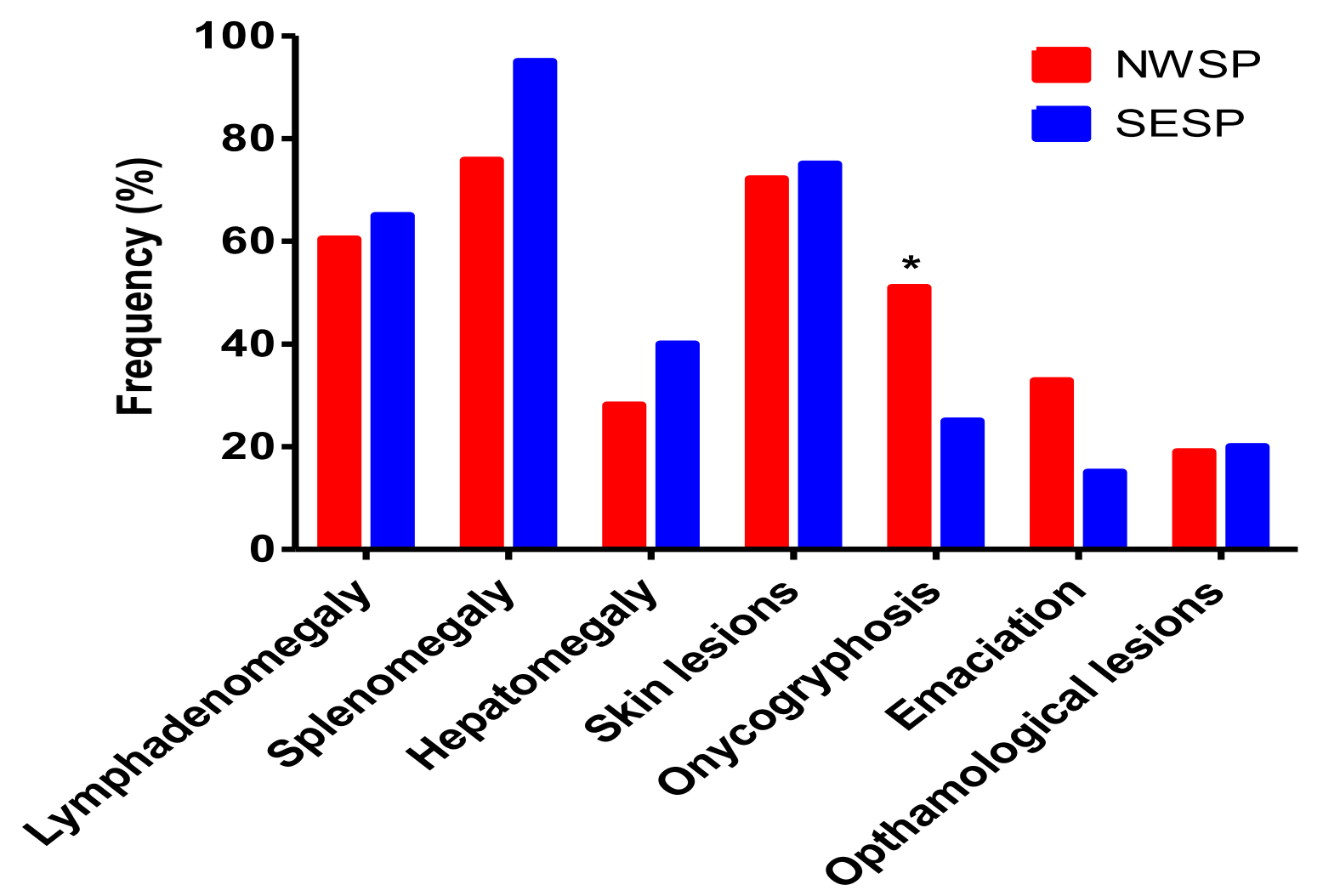

Fig. 2. Frequency distribution of clinical manifestation in dogs naturally infected with Leishmania infantum from two geographic regions of São Paulo state, northwest (NWSP) and southeast (SESP) region of SP. *Statistically significant difference between NWSP and SESP by the Pearson's chi-square test and Fisher's exact test $(p<0.05)$.

\subsubsection{Histopathology examination}

In general, the histology of popliteal lymph nodes from all infected animals showed microscopic lesions that was observed from the capsule to the medullar zones. The capsule of lymph nodes was frequently thickened due to collagen deposition associated to a chronic lymphohistyocitic inflammatory infiltrate, mainly composed by macrophages containing intracytoplasmic amastigotes forms of Leishmania 
("parasitophoruos vacuoles"). The same inflammatory reaction could be detected in the subcapsular sinus, often associated with edema in some cases. The most common histological alteration was a conspicuous hypertrophy and hyperplasia of cortical and/or paracortical area. Cells with large nuclei, branched chromatin and prominent nucleoli (clear zone) delimited by medium-sized lymphocytes (dark zone) characterized the germinal centers, that became contiguous in the outer cortex and moved irregularly into the medullary areas of the node. A diffuse paracortical hyperplasia could be observed in some cases. The medullar areas were tightly packed with differentiated plasma cells, medium-sized and large lymphocytes and macrophages, characterizing different degrees of plasmacytosis and histiocytosis. Granulomatous foci with morphologically differentiated macrophages with large, vesicular nuclei, branched chromatin and abundant cytoplasm (epithelioid cells) were observed in the medullar zone (Supplementary material, Fig. S1).

A semi-quantification of the changes observed in lymph nodes of NWSP and SESP groups of dogs is shown in Fig. 3. Nevertheless, histological findings were in general of a similar magnitude in both groups of infected dogs, with the exception of a slightly greater mononuclear cell (plasma cells, macrophages, lymphocytes) inflammation of the subcapsular sinuses $(p=0.0128)$, and greater number of histiocytes/histiocytosis $(p=0.0077)$ in the SESP group. There was no statistical difference between the groups concerning capsular thickening $(p=0.0686)$, cortical and paracortical hyperplasia $(p=0.2141 ; p=0.2161)$, congestion $(p=0.7021)$, hemosiderosis $(p=0.3782)$ and number of lymphocytes/ plasm cells $(p=0.5736)$, neutrophils ( $p=0.0854)$, eosinophils $(p=0.5881)$ and Mott cells $(p=0.6866)$ (Fig. 3$)$. 


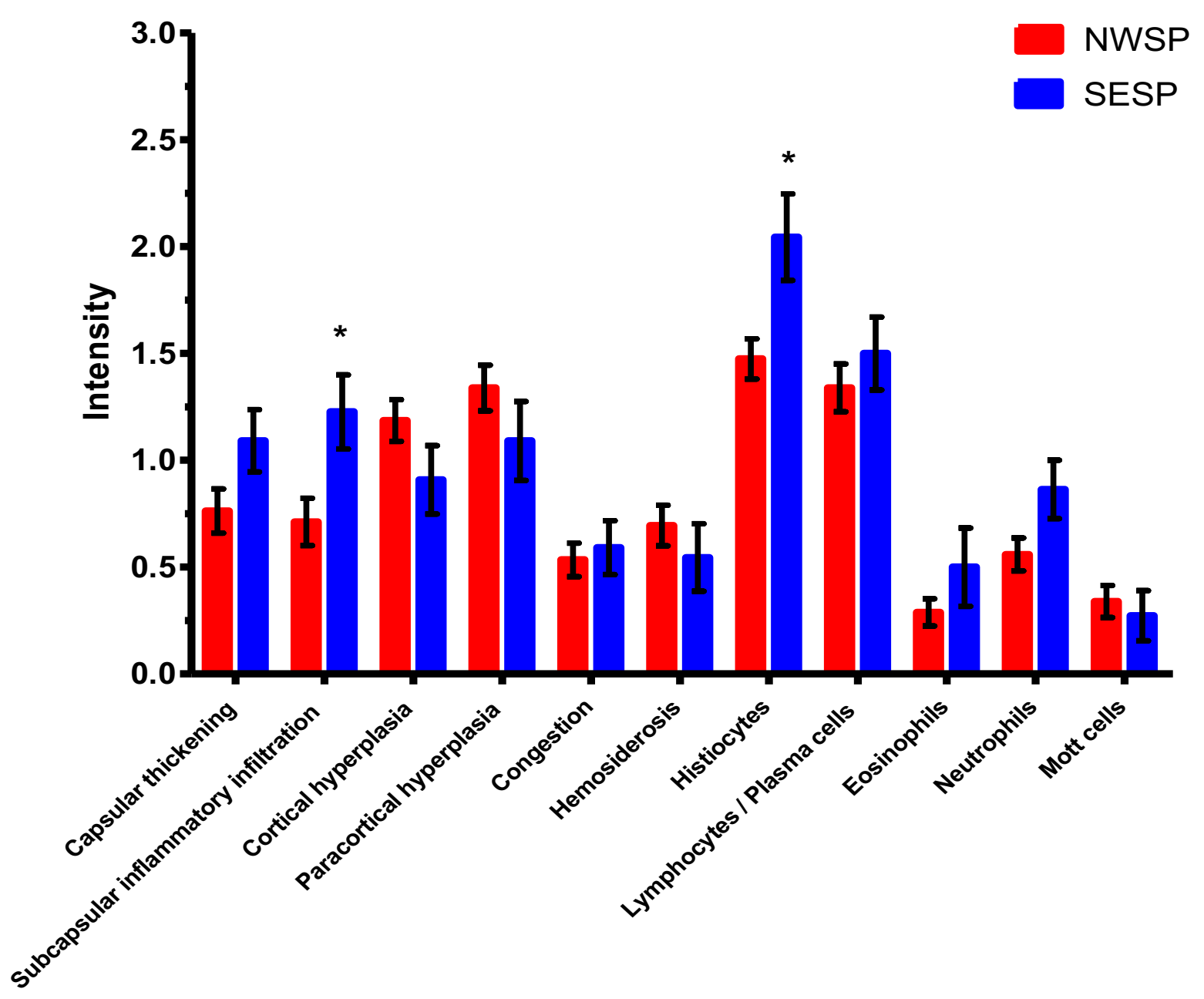

Fig. 3. Histopathological lesions observed in popliteal lymph node of dogs naturally infected with Leishmania infantum from two geographic regions of São Paulo state, northwest (NWSP) and southeast (SESP) region of SP. Criteria adopted to evaluate the intensity of changes: (0) absence of changes; (1) discrete; (2) moderate; (3) intense lesion. *Statistically significant difference between NWSP and SESP by the MannWhitney test $(p<0.05)$.

\subsubsection{Parasite load}

Amastigote forms were found in tissue sections of lymph nodes in all studied animals. Their count in the immunohistochemistry analysis presented wide variation among individuals, with the mean found by microscopic field ranging from 1.6 to 6144 amastigotes $/ \mathrm{mm}^{2}$. Statistical analysis showed a significant difference in the number of amastigotes between the NWSP and SESP groups $(p=0.0004)$, with medians 
[interquartile range] of 275.20 [80.80 - 1221.60] and 60.0 [2.00 - 175.20], respectively. The median number of amastigotes was 4.6 -fold greater in lymph nodes of NWSP dogs than SES dogs (Fig. 4.).

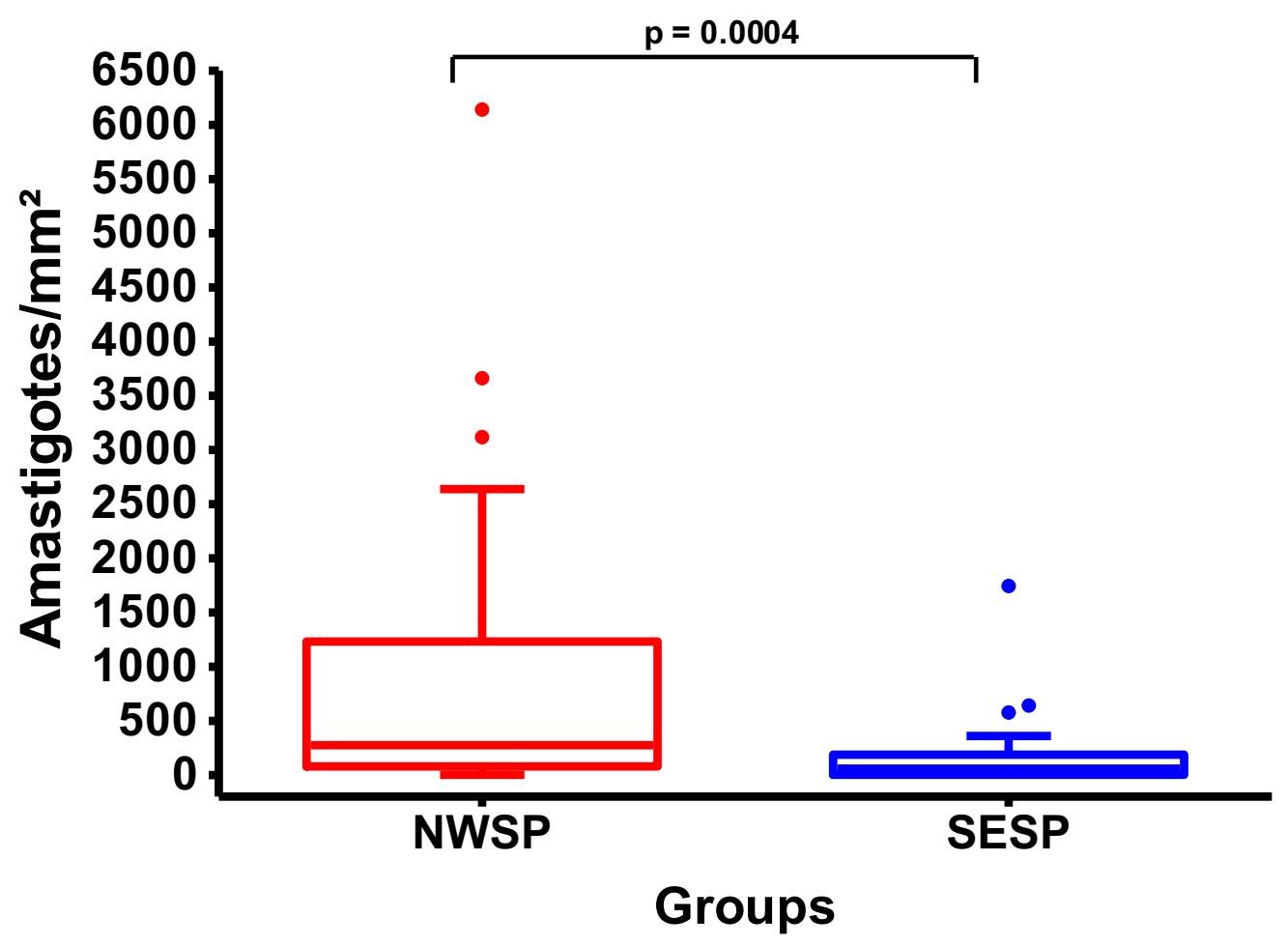

Fig. 4. Quantification of parasite burden in samples of popliteal lymph nodes of dogs naturally infected with Leishmania infantum from two geographic regions of São Paulo state, northwest (NWSP) and southeast (SESP) region of SP. Number of amastigote forms of Leishmania identified by immunohistochemical study in popliteal lymph node sections. Statistically significant difference was identified between NWSP and SESP by the Mann-Whitney test $(p<0.05)$.

\subsubsection{Cytokines and cellular immune profile}

Cytokines and cellular immune immunohistochemical staining in popliteal lymph nodes are presented as Supplementary material (Fig. S2). Regarding the in situ cellular immune response, CD3 immunohistochemical stain highlighted the $\mathrm{T}$ cells mainly in the paracortex and medulla and PAX-5 immunostaining evidenced pro-B to mature B-cell stages mainly in primary and secondary follicles and, also in, the medulla. The median [interquartile range] $\mathrm{IHC}$ scores of $\mathrm{CD}^{+}$and $\mathrm{PAX}-5^{+}$cells in NWSP and SESP were 7.50 [6.00-9.00], 9.00 [7.50-9.00], and 9.00 [7.50-9.00], 7.50 
[7.50-10.50], respectively. No significant difference was observed between the groups ( $p=0.3350$ and $p=0.8850$, respectively).

Cytokine immunostaining showed cellular clusters or scattered cells throughout the parenchyma of the popliteal lymph nodes (Fig. S2). IL-1 $\beta$ and IL-4 scores were significantly higher in lymph nodes of dogs from NWSP region when compared to lymph nodes of dogs from SESP ( $p=0.0275$ and $p=0.0327$, respectively), presenting medians [interquartile range] of 7.00 [4.00-8.50], 4.50 [2.50-7.00], and 4.00 [2.75$6.25], 2.50$ [2.00-4.50], respectively. There was no difference in the popliteal lymph IHC scores of TNF- $\alpha$ and IFN- $\gamma$ between dogs from NWSP and SESP groups ( $p=$ 0.9809 and $p=0.7467$, respectively). Their median [interquartile range] levels were 5.00 [3.00-7.50], 5.00 [3.00-6.75] and 4.50[3.00-6.00], 4.00 [3.00-5.00], respectively. 

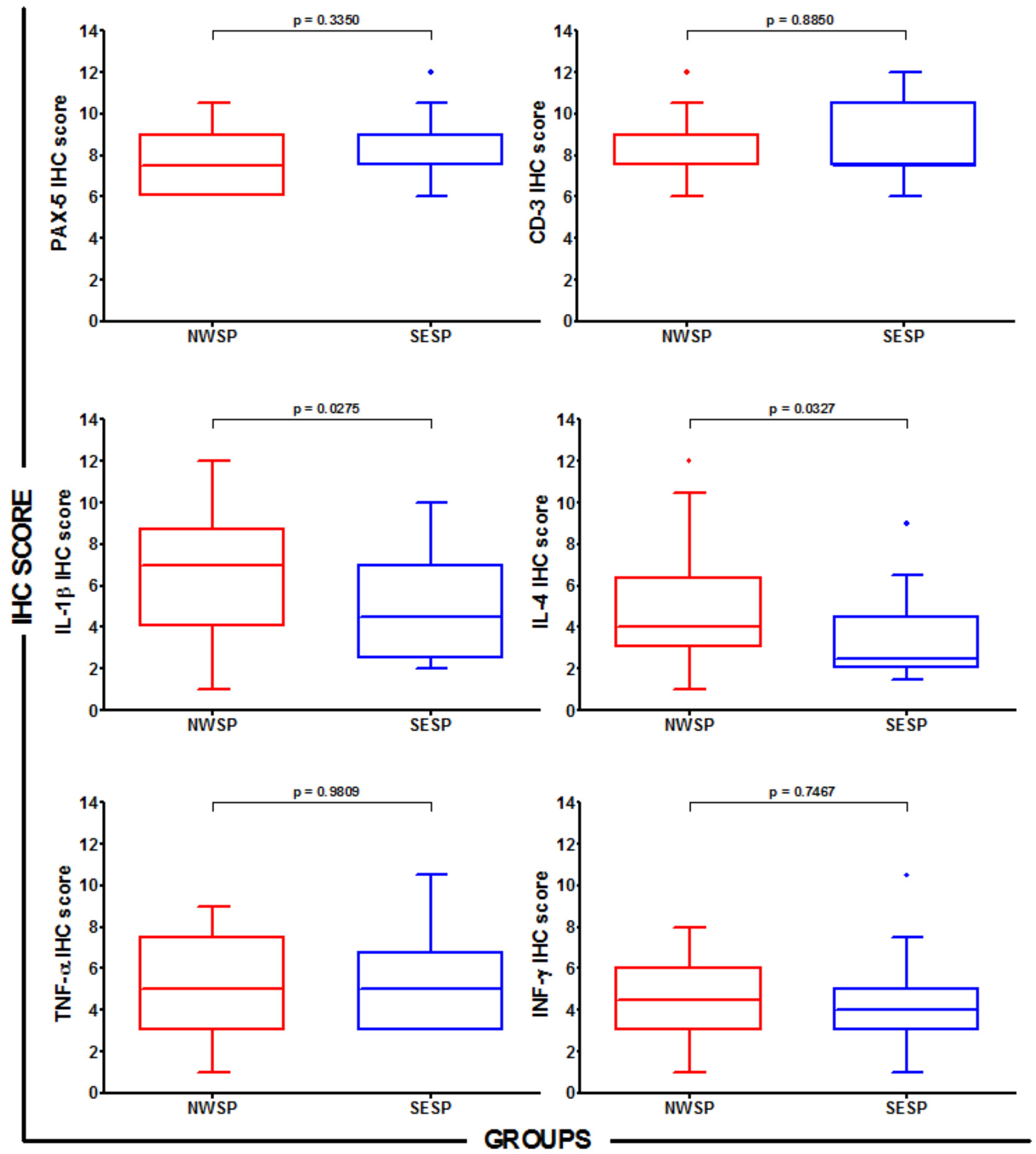

Fig. 5. Immunohistochemical score of cytokine and cellular immune profile in samples of popliteal lymph nodes of dogs naturally infected with Leishmania infantum from two geographic regions of São Paulo state, northwest (NWSP) and southeast (SESP) region of SP. Statistically significant difference between NWSP and SESP by the Mann-Whitney test $(p<0.05)$. 


\subsection{DISCUSSION}

Two distinct epidemiological patterns of VL are recognized and coincident with two different geographic regions of São Paulo state. Many circumstances could contribute to these distinct scenarios, related to the vector (vector abundance, survival, host feeding pattern, blood feeding rate, repeated infectious bites, intradermal injection of sand fly saliva), the parasite (virulence) and the host (genetic background, cellmediated and humoral immune response, cytokine milieu, concurrent diseases) (Baneth et al., 2008; Batista et al., 2018; Casanova et al., 2015; Motoie et al., 2013; Quinnell et al., 2003; Sanchez-Robert et al., 2005; Saridomichelakis, 2009). Two main genetic clusters of $L$. infantum, identified by multilocus microsatellite typing, which also coincides with two L. longipalpis chemotype populations distribution that could be related to differences in ecological parameters of the vector capacity, are described in NWSP and SESP area (Casanova et al., 2015; Motoie et al., 2013). However, host factors should also be considered to explain the variety of eco-epidemiological transmission scenarios. To the best of our knowledge, this is the first study to compare clinical and immunological aspects of dogs naturally infected with $L$. infantum from different municipalities of São Paulo state.

Clinical manifestations of CVL are a consequence of complex interactions between the parasite and host. Factors such as age, gender and breed have not been completely evaluated in relation with the progression of the disease (Alvar et al., 2004). However, field studies in endemic areas do not reveal gender as a crucial risk factor in the case of dogs. Also, the influence of the age in CVL is controversial, although a higher prevalence was observed in old dogs and puppies with immunological deficiencies (Alvar et al., 2004; Quinnell et al., 2003). In theory, all breeds are susceptible to Leishmania infection although it is accepted that some, such as the Ibizan hound have developed a certain level of resistance (Alvar et al., 2004; Baneth et al., 2008; Solano-Gallego et al., 2000) indicating the participation of genetic factors in resistance or susceptibility to disease. In this study, naturally infected mongrel dogs of both genders were randomly selected, representing the real situation of the reservoirs of CVL in Brazil, and divided in two groups (NWSP and SESP) with similar gender distribution. According to the clinical, serological and molecular findings, all dogs included in this study were classified as stage II of CVL, with a diversity of the symptomatic spectrum described for the disease (Brasil, 2006; de Vasconcelos et al., 
2016; Mancianti et al., 1988; Solano-Gallego et al., 2009). Only the frequency of onycogryphosis was higher in animals from the NWSP than from theSESP region. According to Torrecilha et al. (2016), high peripheral parasitism can be inferred in dogs presenting onychogryphosis, which corroborate with our findings, since animals in NWSP also presented higher parasite burden in lymph node tissues.

In CVL, lymph nodes are an important site of parasite proliferation during infection and one of the first organs affected during the systemic dissemination of the parasite (de Vasconcelos et al., 2016). Regional or generalized lymphadenomegaly is also a common clinical sign of the disease (Amusategui et al., 2003; da Costa-Val et al., 2007; Ribeiro et al., 2008). In the present study, this alteration was the third most frequently observed in animals from both NWSP and SESP regions. Hypertrophy and hyperplasia of cortical, paracortical and medullary zones and a chronic lymphoplasmacytic to granulomatous inflammation, with a variable intensity, involving the capsule throughout the medullar region were the histopathological lesions that account for the development of lymphadenopathy in CVL (Alves et al., 2009; Lima et al., 2004) in both groups. In agreement with others cytopathological studies on lymph nodes of dogs infected with L. infantum (Alves et al., 2009; de Vasconcelos et al., 2016; Lima et al., 2004; Moreira et al., 2010), these lesions are also associated to higher number of plasma cells (plasmacytosis) and histiocytes (histiocytosis), observed especially in the SESP group, but without statistical difference when compared to the NWSP group. Interestingly, some studies point to the identification of atrophy of lymph nodes in symptomatic animals (Giunchetti et al., 2008; Moreira et al., 2010), but this finding was not identified in any of our samples, as also described by de Vasconcelos et al. (2016).

In our work, amastigotes were found in popliteal lymph node samples of all dogs naturally infected with $L$. infantum of the NWSP and SESP groups, by immunohistochemistry. This technique allows the detection and quantification of the parasite load, aiding the diagnosis and follow-up of the disease and the evaluation of the response to specific treatment (de Vasconcelos et al., 2016; Moreira et al., 2010; Solano-Gallego et al., 2004; Tafuri et al., 2004). A significantly higher parasite load was detected in the popliteal lymph node samples of dogs from NWSP when compared to SESP group. The presence of Leishmania amastigotes in the lymph nodes is an important indicator of an active infection or disease, due to its potential importance for maintaining immunity (Martínez et al., 2011; Moreira et al., 2010; Torrecilha et al., 
$2017,2016)$, and the parasite burden in this tissue is correlated with infectivity to sand flies, and, consequently, with the transmission of the disease (Laurenti et al., 2013; Ribeiro et al., 2008).

Considering that all animals have similar clinical staging in this study, probably, it may be a contributing factor to explain the distinct eco-epidemiological scenarios in the SP state. Indeed, the NWSP region is characterized by the occurrence of human cases (Cardim et al., 2013), a greater number of municipalities where vectors ( $L$. Longipalpis) are abundant, especially in peridomiciliary environments (Casanova et al., 2013; Holcman et al., 2013) and a high prevalence of canine cases (Holcman et al., 2013; Nunes et al., 2008). In contrast, the SESP region can be defined by the low prevalence of $\mathrm{VL}$ in dogs and humans or even the absence of notified human cases in some municipalities, where the presence of $L$. longipalpis and canine cases have been reported for at least 12 years. The populations of sand flies are generally low in peridomiciliary and rural environments associated with the feeding sources and no occurrence of the natural vector, $L$. longipalpis is described in some municipalities such as Embu das Artes (Colla-Jacques et al., 2010).

The evolution of the disease also is directly related to complex interactions between the parasite and the immune response of the host. Cell-mediated immunity and cytokines play a decisive role in the regulation of the immune response directed against intracellular pathogens like $L$. infantum, determining the prevention or progression of the infection (Hosein et al., 2017). Statistically similar IHC scores of T lymphocytes $\left(\mathrm{CD}^{+}\right)$and $B$ lymphocytes $\left(\mathrm{PAX}-5^{+}\right)$population were evidenced between the NWSP and SESP groups. However, quantifications revealed that IL-1 $\beta$ and IL-4 IHC scores were higher in the group of dogs from NWSP when compared to SESP animals. High levels of these cytokines in lymph nodes may be correlated with the proliferation of the parasite, as in this group parasite load in lymph nodes were also significantly higher when compared to dogs from SESP. IL-1 $\beta$, a potent proinflammatory cytokine, is synthesized through inflammasomal action and secreted by a variety of cell types mainly the innate immune system cells, such as monocytes and macrophages. Thus, it is crucial for host defense response to infection and injury (Man et al., 2017; Patil et al., 2018). Though inflammasome-mediated antimicrobial mechanisms help to clear pathogens, it has also been noticed that excessive inflammation leads to increased pathogenesis (Charmoy et al., 2016; Rossi et al., 2017). For this reason, pro-inflammatory cytokine IL-1 $\beta$ initially may be detrimental to 
intracellular parasitic infection, but later on, it might help to increase parasitic burden (Xin et al., 2007). Still in this context, IL-4 can indicate, among others factors, macrophage activation by alternative pathway toward the parasite survival (Wanasen and Soong, 2008). IL-4 was found to be significantly higher in the skin of leishmaniasis symptomatic dogs (Brachelente et al., 2005). Also, detectable IL-4 mRNA was isolated from bone marrow aspirates of dogs with severe symptoms (Quinnell et al., 2001).

Immunohistochemical scores of TNF- $\alpha$ and IFN- $\gamma$ were similar in lymph nodes of dogs in both groups. These cytokines can be related, besides others associations, to Th1 pathway response, which, when predominant, is associated to protection against canine leishmaniasis (Gradoni, 2015). IFN-Y is a cytokine produced by T cells, dendritic cells, macrophages and natural killer cells (NK) and has the effect of inducing the synthesis of nitric oxide, activating microbicide functions (Reiner and Locksley, 1995; Trinchieri, 1993). TNF- $\alpha$ which is produced, mainly by macrophages, in addition to T cells and NK cells, acts together with IFN- $y$, inducing the production of nitric oxide and therefore the death of amastigotes inside the macrophages (Liew and O'Donnell, 1993). However, it has already been reported that dogs with VL may present a mixed cytokine profile, with pro- and anti-inflammatory cytokines, thus suggesting that the response pattern may become one of type Th2, with immunosuppressive action (Corrêa et al., 2007; Lage et al., 2007). Also, it has been demonstrated that visceral leishmaniasis may progress even in the presence of cytokines related to the Th1 type response, because their action can be neutralized by immunosuppressive factors (Rodrigues et al., 2016). In this sense, our study not demonstrated a clear dichotomy in Th1/Th2 cytokine profile in lymph nodes, however, the increased IHC scores of IL-4 and IL-1 $\beta$ in the NWSP group and the higher parasitic load could corroborate this assertion. Also, the cytokine immune profile observed in dogs from SESP group could be associated to the lower parasitic burden when compared to animals from NWSP groups.

The diversity of eco-epidemiological scenarios in the São Paulo state reflects the parasite-vertebrate/invertebrate hosts adaptation to distinct environmental challenges. In this context, this study shows a significant difference in parasites load and canine immune response profile between CVL dogs from different geographic locations, which may be directly related to lower prevalence rates of the disease in humans and canines in the southeast region of the state. Exploring these differences 
could help the comprehension of visceral leishmaniasis dynamics and the establishment of more efficient control strategies.

\subsection{CONCLUSION}

In conclusion, subcapsular inflammatory infiltration and histiocytosis were significantly higher in lymphoid tissues of dogs naturally infected with $L$. infantum from SESP area. Parasite load in lymph nodes tissues was remarkable higher in dogs from the NWSP than from the SESP group. The higher scores of IL-1 $\beta$ and IL-4 detected in lymph nodes of dogs from NWSP can, among other factors, be associated with the susceptibility of these animals to CVL in this region. Differences in parasitic load and immune response profile can contribute to explain the different eco-epidemiological scenarios of VL in São Paulo state.

\section{Funding}

This work was supported by Grant Program \#12/51267-4, São Paulo Research Foundation (FAPESP), Brazil; Grant Program for the Study of Neglected and Reemerging Diseases, process MCTI/CNPq/MS-SCTIE-Decit N 40/2012; and Projeto Universal CNPq, Brazil (grant number 459489/2014-3). 


\subsection{REFERENCES}

Alvar, J., Cañavate, C., Molina, R., Moreno, J., Nieto, J., 2004. Canine leishmaniasis. Adv. Parasitol. 57, 1-88. https://doi.org/10.1016/S0065-308X(04)57001-X

Alvar, J., Vélez, I.D., Bern, C., Herrero, M., Desjeux, P., Cano, J., Jannin, J., Boer, M. den, 2012. Leishmaniasis Worldwide and Global Estimates of Its Incidence. PLoS One 7, e35671. https://doi.org/10.1371/journal.pone.0035671

Alves, C.F., de Amorim, I.F.G., Moura, E.P., Ribeiro, R.R., Alves, C.F., Michalick, M.S., Kalapothakis, E., Bruna-Romero, O., Tafuri, W.L., Teixeira, M.M., Melo, M.N., 2009. Expression of IFN-gamma, TNF-alpha, IL-10 and TGF-beta in lymph nodes associates with parasite load and clinical form of disease in dogs naturally infected with Leishmania_(Leishmania) chagasi. Vet. Immunol. Immunopathol. 128, 349_ 58. https://doi.org/10.1016/j.vetimm.2008.11.020

Amusategui, I., Sainz, A., Rodríguez, F., Tesouro, M.A., 2003. Distribution and relationships between clinical and biopathological parameters in canine leishmaniasis. Eur. J. Epidemiol. 18, 147-56.

Baneth, G., Koutinas, A.F., Solano-Gallego, L., Bourdeau, P., Ferrer, L., 2008. Canine leishmaniosis - new concepts and insights on an expanding zoonosis: part one. Trends Parasitol. 24, 324-30. https://doi.org/10.1016/j.pt.2008.04.001

Batista, L.F.S., Utsunomiya, Y.T., Silva, T.B.F., Carneiro, M.M., Paiva, J.S.F., Silva, R.B., Tomokane, T.Y., Rossi, C.N., Pacheco, A.D., Torrecilha, R.B.P., Silveira, F.T., Marcondes, M., Nunes, C.M., Laurenti, M.D., 2018. Canine leishmaniasis: Genome-wide analysis and antibody response to Lutzomyia longipalpis saliva. PLoS One 13, e0197215. https://doi.org/10.1371/journal.pone.0197215

Brachelente, C., Müller, N., Doherr, M.G., Sattler, U., Welle, M., 2005. Cutaneous leishmaniasis in naturally infected dogs is associated with a $\mathrm{T}$ helper-2-biased immune response. Vet. Pathol. 42, 166-75. https://doi.org/10.1354/vp.42-2-166

Brasil - Ministério da Saúde do. LEISHMANIOSE VISCERAL-Manual de vigilância e controle. Ministério da Saúde. 2006: 12.

Brasil, 2009. Brasil Guia de vigilância epidemiológica ( $7^{a}$ ed.), Ministério da Saúde, Brasília (2009), p. 816.

Brasil - Ministério da Saúde do. Distribuição do número de casos e óbitos de LVA segundo município e GVE de infecção. Estado de São Paulo, 2010 a 2013. In: 
Centro de Vigilância Epidemiológica do Estado de São Paulo [Internet]. 2015. http://www.cve.saude.sp.gov.br/htm/zoo/lvah Ipi.htm

Brasil - Ministério da Saúde do. Distribuição do número de casos e óbitos de LVA segundo município e GVE de infecção. Estado de São Paulo, 1999 a 2009. In: Centro de Vigilância Epidemiológica do Estado de São Paulo [Internet]. 2013. http://www.cve.saude.sp.gov.br/htm/zoo/lvah9909 Ipi.htm

Breitschwerdt, E.B., Hegarty, B.C., Hancock, S.I., 1998. Sequential evaluation of dogs naturally infected with Ehrlichia canis, Ehrlichia chaffeensis, Ehrlichia equi, Ehrlichia ewingii, or Bartonella vinsonii. J. Clin. Microbiol. 36, 2645-51.

Cardim, M.F.M., Rodas, L.A.C., Dibo, M.R., Guirado, M.M., Oliveira, A.M., Chiaravalloti Neto, F., 2013. Introducao e expansao da Leishmaniose visceral americana em humanos no estado de Sao Paulo, 1999-2011. Rev. Saude Publica 47, 691-700. https://doi.org/10.1590/S0034-8910.2013047004454

Casanova, C., Andrighetti, M.T.M., Sampaio, S.M.P., Marcoris, M.L.G., Colla-Jacques, F.E., Prado, Â.P., 2013. Larval Breeding Sites of Lutzomyia longipalpis (Diptera: Psychodidae) in Visceral Leishmaniasis Endemic Urban Areas in Southeastern $\begin{array}{llllll}\text { Brazil. PLoS Negl. Trop. } & \text { Dis. }\end{array}$ https://doi.org/10.1371/journal.pntd.0002443

Casanova, C., Colla-Jacques, F.E., Hamilton, J.G.C., Brazil, R.P., Shaw, J.J., 2015. Distribution of Lutzomyia longipalpis chemotype populations in São Paulo state, Brazil. PLoS Negl. Trop. Dis. 9, e0003620. https://doi.org/10.1371/journal.pntd.0003620

Charmoy, M., Hurrell, B.P., Romano, A., Lee, S.H., Ribeiro-Gomes, F., Riteau, N., Mayer-Barber, K., Tacchini-Cottier, F., Sacks, D.L., 2016. The NIrp3 inflammasome, IL-1 $\beta$, and neutrophil recruitment are required for susceptibility to a nonhealing strain of Leishmania major in C57BL/6 mice. Eur. J. Immunol. 46, 897-911. https://doi.org/10.1002/eji.201546015

Chow, L., Johnson, V., Coy, J., Regan, D., Dow, S., 2017. Mechanisms of Immune Suppression Utilized by Canine Adipose and Bone Marrow-Derived Mesenchymal Stem Cells. Stem Cells Dev. 26, 374-389. https://doi.org/10.1089/scd.2016.0207 Colla-Jacques, F.E., Casanova, C., Prado, A.P. do, 2010. Study of sand fly fauna in an endemic area of American cutaneous leishmaniasis and canine visceral leishmaniasis in the municipality of Espírito Santo do Pinhal, São Paulo, Brazil. Mem. Inst. Oswaldo Cruz 105, 208-15. 
Corrêa, A.P.F.L., Dossi, A.C.S., de Oliveira Vasconcelos, R., Munari, D.P., de Lima, V.M.F., 2007. Evaluation of transformation growth factor beta1, interleukin-10, and interferon-gamma in male symptomatic and asymptomatic dogs naturally infected by Leishmania (Leishmania) chagasi. Vet. Parasitol. 143, 267-74. https://doi.org/10.1016/j.vetpar.2006.08.023

Costa, M.M.S., Lima, W.G., Figueiredo, M.M., Michalick, M.S.M., Tafuri, W.L., Tafuri, W.L., 2008. Cervical, Mandibular, and Parotid Lymph Nodes of Dogs Naturally Infected with Leishmania infantum : A Histopathologic and Immunohistochemistry Study and Its Correlation with Facial Skin Lesions. Vet. Pathol. 45, 613-616. https://doi.org/10.1354/vp.45-5-613

da Costa-Val, A.P., Cavalcanti, R.R., de Figueiredo Gontijo, N., Michalick, M.S.M., Alexander, B., Williams, P., Melo, M.N., 2007. Canine visceral leishmaniasis: relationships between clinical status, humoral immune response, haematology and Lutzomyia (Lutzomyia) longipalpis infectivity. Vet. J. 174, 636-43. https://doi.org/10.1016/j.tvjl.2006.11.006

de Melo, E.C., Fortaleza, C.M.C.B., 2013. Challenges in the Therapy of Visceral Leishmaniasis in Brazil: A Public Health Perspective. J. Trop. Med. 2013, 1-5. https://doi.org/10.1155/2013/319234

de Vasconcelos, T.C.B., Doyen, N., Cavaillon, J.-M., Bruno, S.F., de Campos, M.P., de Miranda, L.H.M., Madeira, M. de F., Belo, V.S., Figueiredo, F.B., 2016. Cytokine and iNOS profiles in lymph nodes of dogs naturally infected with Leishmania infantum and their association with the parasitic DNA load and clinical and histopathological features. Vet. Parasitol. 227, 8-14. https://doi.org/10.1016/j.vetpar.2016.07.017

Desjeux, P., 2004. Leishmaniasis: current situation and new perspectives. Comp. Immunol. Microbiol. Infect. Dis. 27, 305-18. https://doi.org/10.1016/j.cimid.2004.03.004

Ferreira, E.C., Gontijo, C.M., Cruz, I., Melo, M.N., Silva, A.M., 2010. Alternative PCR protocol using a single primer set for assessing DNA quality in several tissues from a large variety of mammalian species living in areas endemic for leishmaniasis. Mem. Inst. Oswaldo Cruz 105, 895-898. https://doi.org/10.1590/S0074-02762010000700009

Garrido, E. Caracterização imuno-histoquímica de células do infiltrado inflamatório e de citocinas pró e anti-inflamatórias nos carcinomas mamários caninos. 2015. 
Tese de Doutorado - Universidade Estadual Paulista "Júlio de Mesquita Filho" Faculdade de Ciências Agrárias e Veterinárias.

Giunchetti, R.C., Martins-Filho, O.A., Carneiro, C.M., Mayrink, W., Marques, M.J., Tafuri, W.L., Corrêa-Oliveira, R., Reis, A.B., 2008. Histopathology, parasite density and cell phenotypes of the popliteal lymph node in canine visceral leishmaniasis. Vet. Immunol. Immunopathol. 121, 23-33. https://doi.org/10.1016/j.vetimm.2007.07.009

Gradoni, L., 2015. Canine Leishmania vaccines: Still a long way to go. Vet. Parasitol. 208. https://doi.org/10.1016/j.vetpar.2015.01.003

Grimaldi, G., Teva, A., Ferreira, A.L., dos Santos, C.B., Pinto, I. de-S., De-Azevedo, C.T., Falqueto, A., 2012. Evaluation of a novel chromatographic immunoassay based on Dual-Path Platform technology (DPP® CVL rapid test) for the serodiagnosis of canine visceral leishmaniasis. Trans. R. Soc. Trop. Med. Hyg. 106, 54-59. https://doi.org/10.1016/j.trstmh.2011.10.001

Guerra J.M., Fernandes N.C.C.A., Kimura L.M., Shirata N.K., Magno J.A., Abrantes M.F., et al. Avaliação do exame imuno-histoquímico para o diagnóstico de Leishmania spp. em amostras de tecidos caninos. Rev Inst Adolfo Lutz. São Paulo, 2016;75:1686.

Holcman, M.M., Sampaio, S.M.P., Rangel, O., Casanova, C., 2013. Spatial and seasonal distribution of Lutzomyia longipalpis in Dracena, a city in the western region of the State of São Paulo, Brazil, that is endemic with visceral leishmaniasis. Rev. Soc. Bras. Med. Trop. 46, 704-712. https://doi.org/10.1590/0037-8682-0188-2013

Hosein, S., BLAKE, D.P., SOLANO-GALLEGO, L., 2017. Insights on adaptive and innate immunity in canine leishmaniosis. Parasitology 144, 95-115. https://doi.org/10.1017/S003118201600055X

Lovett, M.C., Coates, J.R., Shu, Y., Oglesbee, M.J., Fenner, W., Moore, S.A., 2014. Quantitative assessment of hsp70, IL-1 $\beta$ and TNF- $\alpha$ in the spinal cord of dogs with E40K SOD1-associated degenerative myelopathy. Vet. J. 200, 312317. https://doi.org/10.1016/j.tvil.2014.03.003

Kaneko JJ, Harvey JW, Bruss ML. Appendixes. In: Kaneko JJ, Harvey JW, Bruss ML.

Clinical biochemistry of domestic animals. 5th ed. New York: Academic Press; 1997. p. 885-906. http://dx.doi.org/10.1016/ B978-012396305-5/50032-4 Kordick, S.K., Breitschwerdt, E.B., Hegarty, B.C., Southwick, K.L., Colitz, C.M., 
Hancock, S.I., Bradley, J.M., Rumbough, R., Mcpherson, J.T., MacCormack, J.N., 1999. Coinfection with multiple tick-borne pathogens in a Walker Hound kennel in North Carolina. J. Clin. Microbiol. 37, 2631-8.

Koutinas, A.F., Koutinas, C.K., 2014. Pathologic Mechanisms Underlying the Clinical Findings in Canine Leishmaniosis due to Leishmania infantum/chagasi. Vet. Pathol. 51, 527-538. https://doi.org/10.1177/0300985814521248

Lachaud, L., Chabbert, E., Dubessay, P., Dereure, J., Lamothe, J., Dedet, J.P., Bastien, P., 2002. Value of two PCR methods for the diagnosis of canine visceral leishmaniasis and the detection of asymptomatic carriers. Parasitology 125, $197-$ 207.

Lachaud, L., Marchergui-Hammami, S., Chabbert, E., Dereure, J., Dedet, J.P., Bastien, P., 2002. Comparison of Six PCR Methods Using Peripheral Blood for Detection of Canine Visceral Leishmaniasis. J. Clin. Microbiol. 40, 210-215. https://doi.org/10.1128/JCM.40.1.210-215.2002

Lage, R.S., Oliveira, G.C., Busek, S.U., Guerra, L.L., Giunchetti, R.C., Corrêa-Oliveira, R., Reis, A.B., 2007. Analysis of the cytokine profile in spleen cells from dogs naturally infected by Leishmania chagasi. Vet. Immunol. Immunopathol. 115, 13545. https://doi.org/10.1016/j.vetimm.2006.10.001

Laurenti, M.D., Rossi, C.N., da Matta, V.L.R., Tomokane, T.Y., Corbett, C.E.P., Secundino, N.F.C., Pimenta, P.F.P., Marcondes, M., 2013. Asymptomatic dogs are highly competent to transmit Leishmania (Leishmania) infantum chagasi to the natural vector. Vet. Parasitol. 196, 296-300. https://doi.org/10.1016/j.vetpar.2013.03.017

Liew, F.Y., O'Donnell, C.A., 1993. Immunology of leishmaniasis. Adv. Parasitol. 32, 161-259.

Lima, W.G., Michalick, M.S.M., Melo, M.N. de, Tafuri, W.L., Tafuri, W.L., 2004. Canine visceral leishmaniasis: a histopathological study of lymph nodes. Acta Trop. 92, 43-53. https://doi.org/10.1016/j.actatropica.2004.04.007

Man, S.M., Karki, R., Kanneganti, T.-D., 2017. Molecular mechanisms and functions of pyroptosis, inflammatory caspases and inflammasomes in infectious diseases. Immunol. Rev. 277, 61-75. https://doi.org/10.1111/imr.12534

Mancianti, F., Gramiccia, M., Gradoni, L., Pieri, S., 1988. Studies on canine leishmaniasis control. 1. Evolution of infection of different clinical forms of canine leishmaniasis following antimonial treatment. Trans. R. Soc. Trop. Med. Hyg. 82, 
566-7.

Martínez, V., Quilez, J., Sanchez, A., Roura, X., Francino, O., Altet, L., 2011. Canine leishmaniasis: the key points for qPCR result interpretation. Parasit. Vectors 4, 57. https://doi.org/10.1186/1756-3305-4-57

Michel, G., Pomares, C., Ferrua, B., Marty, P., 2011. Importance of worldwide asymptomatic carriers of Leishmania infantum (L. chagasi) in human. Acta Trop. 119, 69-75. https://doi.org/10.1016/j.actatropica.2011.05.012

Moreira, P.R.R., Vieira, L.M., de Andrade, M.M.C., de Barros Bandarra, M., Machado, G.F., Munari, D.P., Vasconcelos, R. de O., de Oliveira Vasconcelos, R., 2010. Immune response pattern of the popliteal lymph nodes of dogs with visceral leishmaniasis. Parasitol. Res. 107, 605-13. https://doi.org/10.1007/s00436-0101902-2

Motoie, G., Ferreira, G.E.M., Cupolillo, E., Canavez, F., Pereira-Chioccola, V.L., 2013. Spatial distribution and population genetics of Leishmania infantum genotypes in São Paulo State, Brazil, employing multilocus microsatellite typing directly in dog infected tissues. Infect. Genet. Evol. 18, 48-59. https://doi.org/10.1016/j.meegid.2013.04.031

Nunes, C.M., Lima, V.M.F. de, Paula, H.B. de, Perri, S.H.V., Andrade, A.M. de, Dias, F.E.F., Burattini, M.N., 2008. Dog culling and replacement in an area endemic for visceral leishmaniasis in Brazil. Vet. Parasitol. 153, 19-23. https://doi.org/10.1016/j.vetpar.2008.01.005

Patil, T., More, V., Rane, D., Mukherjee, A., Suresh, R., Patidar, A., Bodhale, N., Mosser, D., Dandapat, J., Sarkar, A., 2018. Pro-inflammatory cytokine Interleukin$1 \beta$ (IL-1 $\beta)$ controls Leishmania infection. Cytokine 112, 27-31. https://doi.org/10.1016/j.cyto.2018.06.033

Pinelli, E., Killick-Kendrick, R., Wagenaar, J., Bernadina, W., del Real, G., Ruitenberg, J., 1994. Cellular and humoral immune responses in dogs experimentally and naturally infected with Leishmania infantum. Infect. Immun. 62, 229-35.

Quinnell, R.J., Courtenay, O., Davidson, S., Garcez, L., Lambson, B., Ramos, P., Shaw, J.J., Shaw, M.A., Dye, C., 2001. Detection of Leishmania infantum by PCR, serology and cellular immune response in a cohort study of Brazilian dogs. Parasitology 122, 253-61.

Quinnell, R.J., Kennedy, L.J., Barnes, A., Courtenay, O., Dye, C., Garcez, L.M., Shaw, M.-A., Carter, S.D., Thomson, W., Ollier, W.E.R., 2003. Susceptibility to visceral 
leishmaniasis in the domestic dog is associated with MHC class II polymorphism. Immunogenetics 55, 23-8. https://doi.org/10.1007/s00251-003-0545-1

Reiner, S.L., Locksley, R.M., 1995. The regulation of immunity to Leishmania major. Annu. Rev. Immunol. 13, 151-77. https://doi.org/10.1146/annurev.iy.13.040195.001055

Reis, L.L. dos, Balieiro, A.A. da S., Fonseca, F.R., Gonçalves, M.J.F., 2017. Changes in the epidemiology of visceral leishmaniasis in Brazil from 2001 to 2014. Rev. Soc. Bras. Med. Trop. 50, 638-645. https://doi.org/10.1590/0037-8682-02432017

Remmele, W., Stegner, H.E., 1987. [Recommendation for uniform definition of an immunoreactive score (IRS) for immunohistochemical estrogen receptor detection (ER-ICA) in breast cancer tissue]. Pathologe 8, 138-40.

Ribeiro, R.R., Moura, E.P., Pimentel, V.M., Sampaio, W.M., Silva, S.M., Schettini, D.A., Alves, C.F., Melo, F.A., Tafuri, W.L., Demicheli, C., Melo, M.N., Frézard, F., Michalick, M.S.M., 2008. Reduced tissue parasitic load and infectivity to sand flies in dogs naturally infected by Leishmania (Leishmania) chagasi following treatment with a liposome formulation of meglumine antimoniate. Antimicrob. Agents Chemother. 52, 2564-72. https://doi.org/10.1128/AAC.00223-08

Roatt, B.M., Aguiar-Soares, R.D. de O., Reis, L.E.S., Cardoso, J.M. de O., Mathias, F.A.S., de Brito, R.C.F., da Silva, S.M., Gontijo, N.D.F., Ferreira, S. de A., Valenzuela, J.G., Corrêa-Oliveira, R., Giunchetti, R.C., Reis, A.B., 2017. A Vaccine Therapy for Canine Visceral Leishmaniasis Promoted Significant Improvement of Clinical and Immune Status with Reduction in Parasite Burden. Front. Immunol. 8, 217. https://doi.org/10.3389/fimmu.2017.00217

Rodrigues, V., Cordeiro-da-Silva, A., Laforge, M., Silvestre, R., Estaquier, J., 2016. Regulation of immunity during visceral Leishmania infection. Parasit. Vectors 9, 118. https://doi.org/10.1186/s13071-016-1412-x

Rossi, M., Castiglioni, P., Hartley, M.-A., Eren, R.O., Prével, F., Desponds, C., Utzschneider, D.T., Zehn, D., Cusi, M.G., Kuhlmann, F.M., Beverley, S.M., Ronet, C., Fasel, N., 2017. Type I interferons induced by endogenous or exogenous viral infections promote metastasis and relapse of leishmaniasis. Proc. Natl. Acad. Sci. U. S. A. 114, 4987-4992. https://doi.org/10.1073/pnas.1621447114

Sanchez-Robert, E., Altet, L., Sanchez, A., Francino, O., 2005. Polymorphism of Slc11a1 (Nramp1) gene and canine leishmaniasis in a case-control study. J. 
Hered. 96, 755-8. https://doi.org/10.1093/jhered/esi111

Saridomichelakis, M.N., 2009. Advances in the pathogenesis of canine leishmaniosis:

epidemiologic and diagnostic implications. Vet. Dermatol. 20, 471-89. https://doi.org/10.1111/j.1365-3164.2009.00823.x

SES, Secretaria do Estado da Saúde. LEISHMANIOSE VISCERAL Casos confirmados de Leishmaniose Visceral segundo LPI e ano de notificação, Estado. In: Secretaria de Estado da Saúde [Internet]. 2017 pp. 0-1. http://www.saude.sp.gov.br/resources/cve-centro-de-vigilanciaepidemiologica/areas-de-vigilancia/doencas-de-transmissao-por-vetores-ezoonoses/dados/leish/lv sh gve.pdf

Seixas Duarte, M.I., Tuon, F.F., Pagliari, C., Kauffman, M.R., Brasil, R.A., 2008. Human visceral leishmaniasis expresses Th1 pattern in situ liver lesions. J. Infect. 57, 332-7. https://doi.org/10.1016/j.jinf.2008.07.005

Solano-Gallego, L., Fernández-Bellon, H., Morell, P., Fondevila, D., Alberola, J., Ramis, A., Ferrer, L., 2004. Histological and immunohistochemical study of clinically normal skin of Leishmania infantum-infected dogs. J. Comp. Pathol. 130, 7-12.

Solano-Gallego, L., Koutinas, A., Miró, G., Cardoso, L., Pennisi, M.G., Ferrer, L., Bourdeau, P., Oliva, G., Baneth, G., 2009. Directions for the diagnosis, clinical staging, treatment and prevention of canine leishmaniosis. Vet. Parasitol. 165, 118. https://doi.org/10.1016/j.vetpar.2009.05.022

Solano-Gallego, L., Llull, J., Ramos, G., Riera, C., Arboix, M., Alberola, J., Ferrer, L., 2000. The Ibizian hound presents a predominantly cellular immune response against natural Leishmania infection. Vet. Parasitol. 90, 37-45.

Tafuri, W.L., Santos, R. de L., Arantes, R.M.E., Gonçalves, R., de Melo, M.N., Michalick, M.S.M., Tafuri, W.L., 2004. An alternative immunohistochemical method for detecting Leishmania amastigotes in paraffin-embedded canine tissues. J. Immunol. Methods 292, 17-23. https://doi.org/10.1016/i.jim.2004.05.009

Thalheim, L., Williams, L.E., Borst, L.B., Fogle, J.E., Suter, S.E., 2013. Lymphoma Immunophenotype of Dogs Determined by Immunohistochemistry, Flow Cytometry, and Polymerase Chain Reaction for Antigen Receptor Rearrangements. J. Vet. Intern. Med. 27, 1509-1516. https://doi.org/10.1111/jvim.12185 
Torrecilha, R.B.P., Utsunomiya, Y.T., Batista, L.F. da S., Bosco, A.M., Nunes, C.M., Ciarlini, P.C., Laurenti, M.D., 2017. Prediction of lymph node parasite load from clinical data in dogs with leishmaniasis: An application of radial basis artificial neural networks. Vet. Parasitol. 234, 13-18. https://doi.org/10.1016/j.vetpar.2016.12.016

Torrecilha, R.B.P., Utsunomiya, Y.T., Bosco, A.M., Almeida, B.F., Pereira, P.P., Narciso, L.G., Pereira, D.C.M., Baptistiolli, L., Calvo-Bado, L., Courtenay, O., Nunes, C.M., Ciarlini, P.C., 2016. Correlations between peripheral parasite load and common clinical and laboratory alterations in dogs with visceral leishmaniasis. Prev. Vet. Med. 132, 83-87. https://doi.org/10.1016/j.prevetmed.2016.08.006 Trinchieri, G., 1993. Interleukin-12 and its role in the generation of TH1 cells. Immunol. Today 14, 335-8. https://doi.org/10.1016/0167-5699(93)90230-I

Tuon, F.F., Duarte, M.I.S., Amato, V.S., n.d. A quantitative and morphometric study of mast cells in cutaneous leishmaniasis. Parasite Immunol. 30, 641-5. https://doi.org/10.1111/j.1365-3024.2008.01057.x

Tuon, F.F., Gomes-Silva, A., Da-Cruz, A.M., Duarte, M.I.S., Neto, V.A., Amato, V.S., 2008. Local immunological factors associated with recurrence of mucosal leishmaniasis. Clin. Immunol. 128, 442-6. https://doi.org/10.1016/j.clim.2008.05.007

Tuon, F.F., Guedes, F., Fernandes, E.R., Pagliari, C., Amato, V.S., Seixas Duarte, M.I., 2009. In situ immune responses to interstitial pneumonitis in human visceral leishmaniasis. Parasite Immunol. 31, 98-103. https://doi.org/10.1111/j.13653024.2008.01080.x

Wanasen, N., Soong, L., 2008. L-arginine metabolism and its impact on host immunity against Leishmania infection. Immunol. Res. 41, 15-25. https://doi.org/10.1007/s12026-007-8012-y

Werneck GL. Forum: geographic spread and urbanization of visceral leishmaniasis in Brazil. Introduction. Cad saude publica / Minist da Saude, Fund Oswaldo Cruz, Esc Nac Saude Publica. 2008;24: 2937-2940.

Willmann, M., Müllauer, L., Guija de Arespacochaga, A., Reifinger, M., Mosberger, I., Thalhammer, J.G., 2009. Pax5 immunostaining in paraffin-embedded sections of canine non-Hodgkin lymphoma: A novel canine pan pre-B- and B-cell marker. Vet. Immunol. Immunopathol. 128, 359-365. https://doi.org/10.1016/j.vetimm.2008.11.019 
WHO, 2017. WHO: Weekly epidemiological record: Global leishmaniasis update, 2006-2015, a turning point in leishmaniasis surveillance. World Heal. Organ. 92. https://doi.org/10.1186/1750-9378-2-15.Voir

Xin, L., Li, Y., Soong, L., 2007. Role of interleukin-1beta in activating the CD11c(high) CD45RB- dendritic cell subset and priming Leishmania amazonensis-specific CD4+ $T$ cells in vitro and in vivo. Infect. Immun. 75, 5018-26. https://doi.org/10.1128/IAl.00499-07 


\section{Supplementary material}

Table S1. General and descriptive statistics for each group for serum biochemical parameters.

\begin{tabular}{c|c|c|c|c|c|c}
\hline \multicolumn{1}{c|}{ Analyte } & Group & Median & Q1 & Q3 & N & P-value \\
\hline \multirow{2}{*}{ Urea (mg/dL) } & NWSP & 31.00 & 23.85 & 46.50 & 61 & \multirow{2}{*}{0.3694} \\
\cline { 2 - 6 } & SESP & 34.90 & 27.67 & 46.25 & 22 & \\
\hline Creatinine (mg/dL) & NWSP & 1.09 & 0.90 & 1.21 & 61 & \multirow{2}{*}{0.1501} \\
\cline { 2 - 6 } & SESP & 1.215 & 0.83 & 1.3725 & 22 & \\
\hline GPT / ALT (U/dL) & NWSP & 12.0 & 5.62 & 27.0 & 61 & \multirow{2}{*}{0.9301} \\
\cline { 2 - 6 } & SESP & 17.34 & 4.14 & 31.25 & 22 & \\
\hline GOT / AST (U/dL) & NWSP & 18.40 & 12.0 & 26.0 & 61 & \multirow{2}{*}{0.2522} \\
\cline { 2 - 6 } & SESP & 15.0 & 10.0 & 20.0 & 15 & \\
\hline AP (U/dL) & NWSP & 78.0 & 34.0 & 106.0 & 52 & \multirow{2}{*}{0.5946} \\
\cline { 2 - 6 } TP (g/dL) & SESP & 106.0 & 27.8 & 126.3 & 15 & \\
\hline Albumin (g/dL) & NWSP & 7.65 & 5.7 & 9.75 & 46 & \multirow{2}{*}{0.9515} \\
\cline { 2 - 6 } & SESP & 6.9 & 5.75 & 9.65 & 21 & \\
\cline { 2 - 6 } & NWSP & 3.03 & 2.8 & 3.38 & 60 & \multirow{2}{*}{0.7181} \\
\hline
\end{tabular}

NWSP: northwest region of São Paulo state; SESP: southeast region of São Paulo state. GPT / ALT: glutamate-pyruvate transaminase/ alanine aminotransferase, GOT / AST: glutamic-oxaloacetic transaminase/ aspartate aminotransferase; TP: total protein; AP: alkaline phosphatase; Q1: First quartile; Q3: Third quartile. 


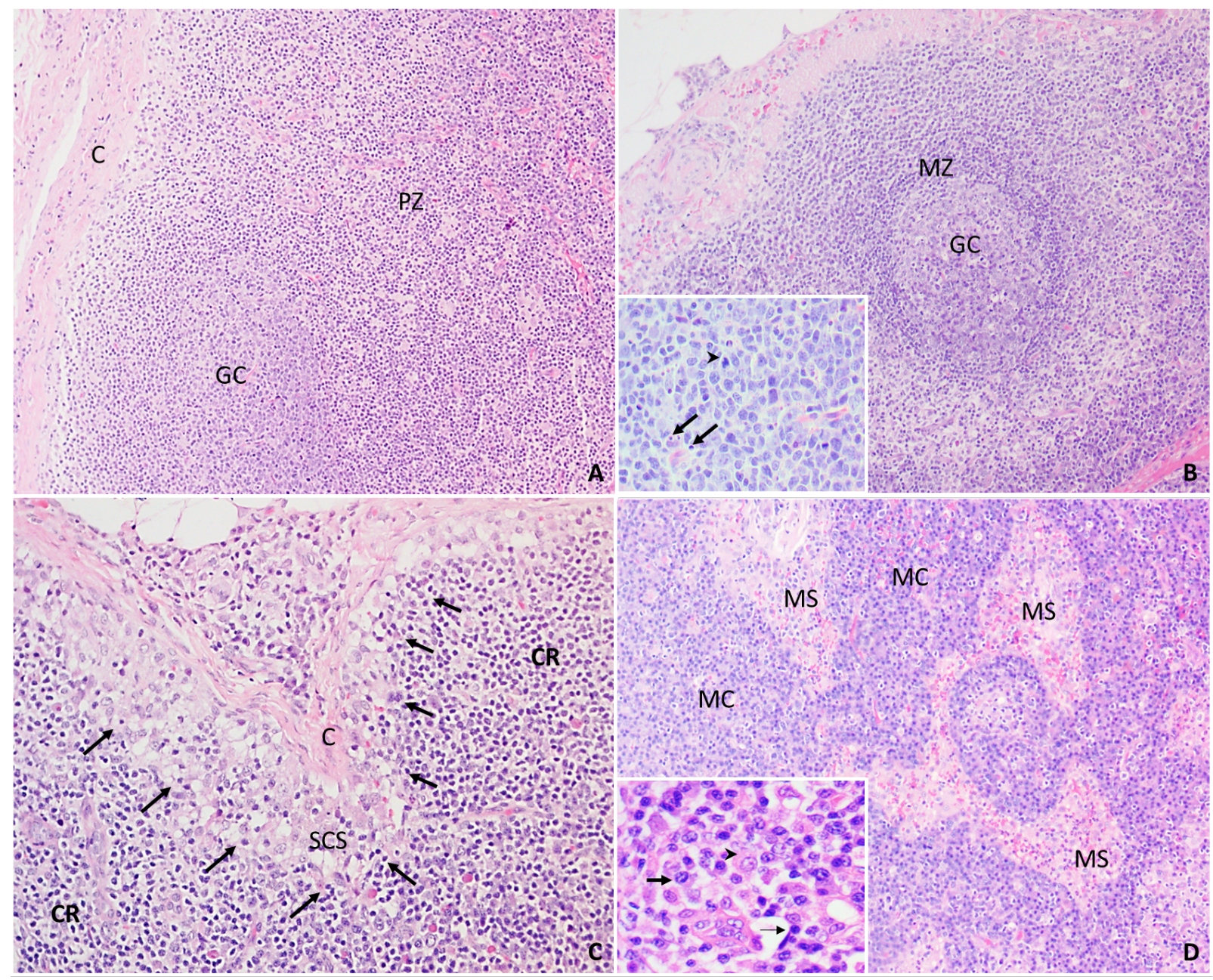

Fig. S1. Popliteal lymph node, dog. (A) The capsule (C) is thickened with a mild infiltration of mononuclear inflammatory cells. The cortical region showed moderate follicular hyperplasia with germinal centers (GC) and diffuse hyperplasia in paracortical zone (PZ). Hematoxylin and eosin (H\&E), 10x. (B) Lymphoid follicles hyperplasia with GC showing dark and clear zones and a distinct follicle mantle zone (MZ), 20x. In the detail, lymphocytes with large nuclei, branched chromatin and prominent nucleoli (clear zone of GC). Note tingible-body macrophages contain fragments of apoptotic lymphocytes (apoptotic bodies) (arrows) and mitotic figures (arrowheads), 40x. H\&E. (C) Inflammatory reaction (arrows) and edema in the subcapsular sinus (SCS) and hyperplasia of lymphocytes in cortical region (CR), 20x. H\&E. (DI) Medullary cords (MC) and sinus (MS) occupied by higher numbers of mononuclear cells, 20x. In detail, increased numbers of plasma cells (large arrows), lymphocytes (thin arrows), and macrophages (arrowheads) in the medullary cords, 40x. H\&E. 


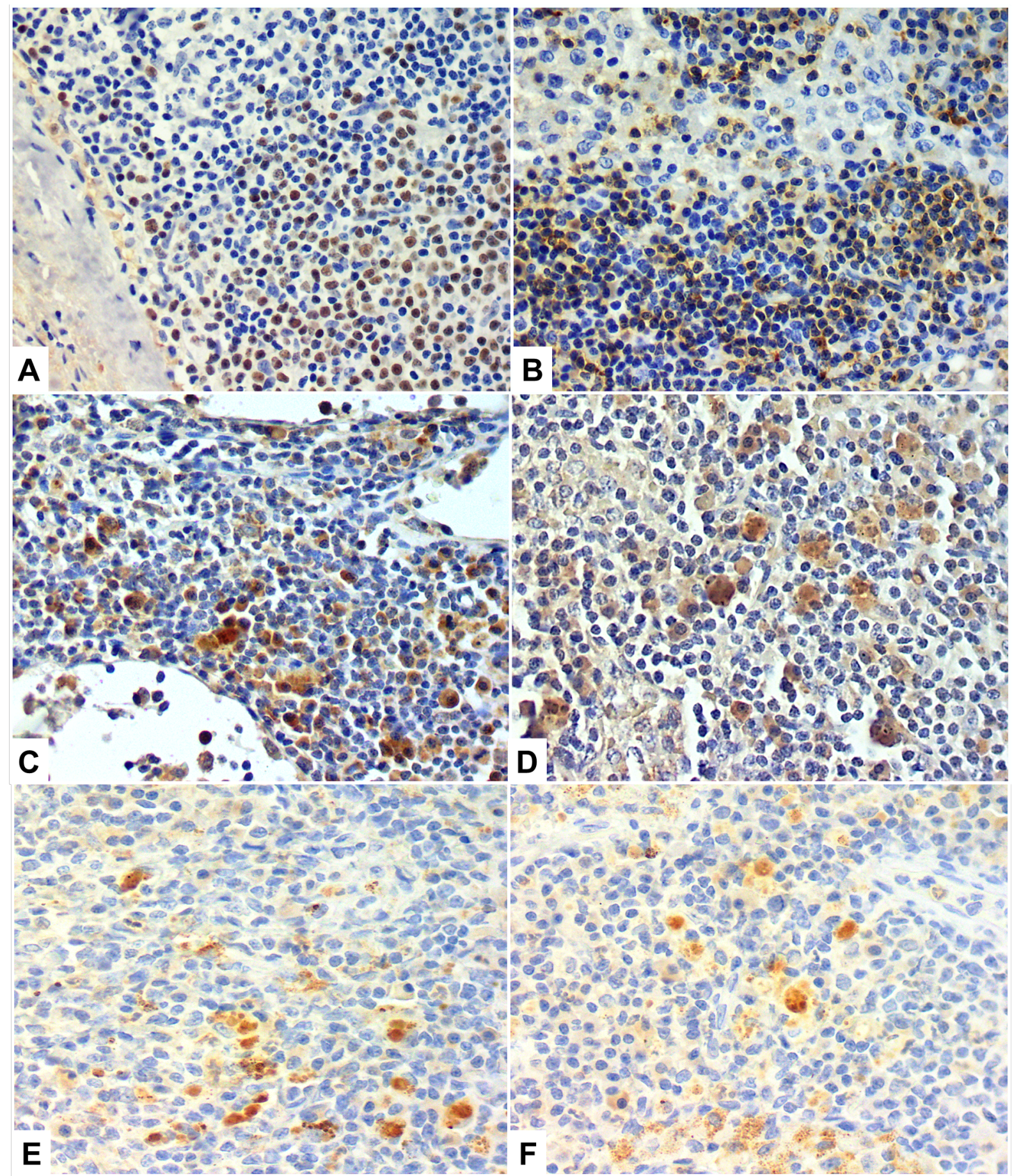

Fig. S2. Immunohistochemical findings in popliteal lymph node, dog with CVL. (A) Marked nuclear positive immunolabeling for PAX-5 in B cells lymphocytes predominantly in cortex region, 40x. (B) IHC reveals membranous expression of CD3 in $T$ cells lymphocytes in medullary cords and sinus, 40x. (C) Marked, multifocal positive immunolabeling for IL-1 $\beta$ in lymph node, 40x. (D) IL-4 marked positive cells in the medullary region, 40x. (E) Multifocal distribution of TNF- $\alpha$ positivity in paracortical zone, 40x. (F) Marked multifocal positive immunolabeling for INF-y also in PZ, 40x. 


\section{EVALUATION OF L. INFATUM GENETIC MARKER ON CHROMOSSOME 31 IN DOGS NATURALLY INFECTED IN SÃO PAULO STATE, BRAZIL}

\subsection{ABSTRACT}

In Brazil, visceral leishmaniasis (VL) is a zoonotic disease caused by L. infantum and transmitted by sand flies of the Lutzomyia genus. The disease is expanding through the São Paulo state, where it presents a distinct temporal-geographic pattern, first appearing in the northwestern (NWSP) region, and after spreading to southeasterly (SESP) direction over time. Domestic dogs represent the principal reservoir hosts in domiciliary and peri-domiciliary area. Rapid genetic change in $L$. infantum is of concern to public health, since parasite intra-specific genetic variation is associated to major differences in pathology, drug resistance and other eco-epidemiological traits. A large chromosomal deletion comprises both helicase and 3 ' nucleotidase genes on tetraploid (supernumerary) chromosome 31, that distinguishes a widespread, monophyletic group of $L$. infantum strains was described in isolates from Brazil. This study aimed to address the epidemiological and clinical correlation of this specific parasite genotype in lymphoid samples of dogs naturally infected from São Paulo (SP) state, Brazil. The deletion genotype of $L$. infatum was predominantly identified in the southeast of SP state, with a frequency of $44.44 \%$, while the non-deletion genotype was observed in the northwest municipalities of SP state, in $35.19 \%$ of the samples $(p=0.01945)$. Eight $(14.81 \%)$ and three $(5.56 \%)$ samples from NWSP demonstrated a third, mixed profile for the deleted site, representing heterozygosity equivalent and non-equivalent, respectively. No statistical difference was observed between the specific genotype and the clinical status $(p=0.7183)$ and the parasite burden $(p=0.913)$ in the popliteal lymph node samples of the dogs. All these data together contributed to the detection of the genetic profile of $L$. infantum population and the epidemiology of CVL in SP state.

Keywords: visceral leishmaniasis, canine, genotype, biomarker 


\subsection{INTRODUCTION}

Visceral leishmaniasis $(\mathrm{VL})$ is a major public health problem in Latin America, with more than $90 \%$ of the cases occurring in Brazil, where it affects approximately 3,200 individuals per year (PAHO, 2018). VL is caused by a protozoan parasite Leishmania (Leishmania) infantum and transmitted by the bite of infected phlebotomine sandflies during blood feeding (Lainson and Shaw, 1978). The domestic dogs are considered the main urban and peri-urban reservoirs of disease (Molina et al., 1994, Moreno and Alvar, 2002) presenting similar pathophysiological aspects to human disease (Burza et al., 2018). In addition, canine visceral leishmaniasis (CVL) usually precedes and is highly associated with cases of human disease (Moreno and Alvar, 2002; Ribeiro et al., 2018).

CVL is a complex disease in which infection may be subclinical, a self-limiting disease, or a severe, and sometimes, fatal illness (Reis et al., 2009, Solano-Gallego et al., 2009). Factors or mechanisms leading to the diversity of clinical presentations are not well known. Although the involvement of host immune response (Saporito et al., 2013; Reis et al., 2009), and, a limited number of parasite factors also have lately been recognized as important (Ferreira et al., 2012; Kuhls et al., 2007; Ochsenreither et al., 2006). Leishmania intra-specific genetic variation is associated with major differences in pathology, drug resistance and other eco-epidemiological traits, thus, known the genetic diversity of $L$. infantum is important to public health (Ishikawa et al., 2002; Cupolillo et al.,2003).

In this context, Boite, M.C. described a large chromosomal deletion that distinguishes a monophyletic group of widespread $L$. infantum strains from less abundant variants found among parasite's genotypes in Brazil (personal communication). The deletion comprises both helicase and 3' nucleotidase/nuclease (3' NT/NU) genes on tetraploid (supernumerary) chromosome 31. Helicases are essential for DNA replication and repair in eukaryotes but occur abundantly on various $L$. infantum chromosomes. The $3^{\prime} \mathrm{NT} / \mathrm{NU}$ enzyme, in contrast, is unique to trypanosomatid protozoa and an orthologue with similar functions is encoded only on one other locus in the L. infantum genome (on chromosome 12). This surface membrane protein participates in purine salvage essential to trypanosomatid survival. Its activity in Leishmania parasites also promotes macrophage infection and escape from neutrophil extracellular traps (NETs), a primary mechanism of host defence 
(Freitas-Mesquita et al., 2016; Freitas-Mesquita and Meyer-Fernandes, 2017; Guimarães-Costa et al., 2014, 2009). Correlations to virulence are also often observed (Guimaraes-Costa et al., 2009).

Thus, the aim of the currently study is to analyze the distribution of this specific deletion in LinJ.31.2380 locus of $L$. infantum population from SP state in Brazil, a region with a recent geographical expansion, urbanization and increase prevalence of VL. In addition, we investigated the association between the genetic genotype to the clinical signs and to the parasite load in popliteal lymph node tissues from dogs naturally infected with $L$. infantum.

\subsection{MATERIAL AND METHODS}

\subsubsection{Ethics Statement}

The infected animals included in this study were submitted to euthanasia as recommended by the guidelines of the Brazilian Ministry of Health (Brasil, 2006) at the Center for Zoonosis Control. All procedures were conducted in accordance to ethical principles established by the National Council for Animal Experiments Control CONCEA and in accordance with national legislation (No. 11.794, of August 8, 2008 and No. 9605 of February 12, 1998). In addition, all experimental procedures in this study were approved by the Ethics Committee on Animal Experimentation of the Instituto Adolfo Lutz (CEUA $n^{\circ}$. 01/2016) and School of Veterinary Medicine and Animal Science of University of São Paulo (CEUA nº. 4079280115). For euthanasia, dogs were contained, sedated and pre-anesthetized with xylazine hydrochloride (1.0 $\mathrm{mg} / \mathrm{kg}$ ) (Vetbrands, Brazil), ketamine hydrochloride $(10 \mathrm{mg} / \mathrm{kg}$ ) (Agener, Brazil) and diazepam $(1.0 \mathrm{ml} / 10 \mathrm{~kg}$ ) (Hipolabor, Brazil) by intramuscular injection. Then, all animals were anesthetized with an intravenous injection of $2.5 \%(1.0 \mathrm{ml} / \mathrm{kg})$ Thiopental (intravenous). Once the absence of corneal reflex induced by deep anesthesia was archived, $10.0 \mathrm{~mL}$ of $19.1 \%$ Potassium Chloride (Isofarma) or $3 \mathrm{~mL}$ of T61TM (0.3 $\mathrm{ml} / \mathrm{kg}$ ) were administered by intravenous injection until reach respiratory and subsequent cardiac arrest. 


\subsubsection{Animals and study design}

A cross-sectional study was conducted with a convenience sample of 54 mongrel dogs from the Center of Zoonosis Control of distinct municipalities (Araçatuba, Caieirias, Embú das Artes, Fernandópolis, Itapira, Jales, Santa Fé do Sul, Votuporanga) of São Paulo (SP) State, Brazil. The study included animals older than six months of age, regardless of gender, with positive serological results for Leishmania sp. by Immunochromatographic Rapid Test - Dual Path Platform (DPP®) - BioManguinhos $® / F I O C R U Z$ and Enzyme-Linked Immunosorbent Assay (ELISA) performed by Public Offices, Leishmania infantum infection confirmed by a specific conventional PCR in popliteal lymph nodes samples. Dogs were allocated into groups according to the mutation status on LinJ.31.2380 locus, associated with geographic distribution and parasite load.

\subsubsection{Clinical evaluation}

Clinical evaluation was performed by two veterinarians according to the presence of clinical signs and symptoms suggestive of CVL, such as cachexia, lymphadenomegaly, hepatosplenomegaly, skin disorders, onychogryphosis and ophthalmologic abnormalities in a standardized clinical form. After clinical and serum biochemical evaluation, the animals were classified in clinical stage using the LeishVet clinical staging system (Solano-Gallego et al. 2009).

\subsubsection{Sample collection and storage}

Blood samples were obtained using venipuncture of the cephalic or jugular vein and were collected in tubes containing a coagulation activator and a gel separator. Tubes were allowed to clot at room temperature. Sera were obtained by centrifugation at $3500 \mathrm{~g}$ for $5 \mathrm{~min}$, aliquoted, and stored at $-20^{\circ} \mathrm{C}$ until serological detection of antiLeishmania antibodies and for serum biochemistry evaluation. Immediately after euthanasia, fragments of popliteal lymph nodes were harvested in RNAlater Tissue Collection solution (Ambion, Applied Biosystems, Life Technologies Corporation) for DNA extraction. The biopsies were frozen and stored at $-70^{\circ} \mathrm{C}$ prior to processing. 


\subsubsection{Serological methods}

The immunological tests performed were Dual-Path Platform CVL rapid test (TR DPP® Leishmaniosis Visceral Canina, Bio-Manguinhos, Rio de Janeiro, Brazil), composed of specific recombinant proteins (rK26 and rK39), and enzyme-linked immunosorbent (ELISA EIE®) (Bio-Manguinhos, FIOCRUZ, Rio de Janeiro, Brazil) (Grimaldi et al., 2012), distributed by the Ministry of Health (Brazil), and executed as recommended by the manufacturer's instructions at the Parasitology and Mycology at Adolfo Lutz Institute, the Central Laboratory of Sao Paulo state, from State Department of Health, São Paulo state.

\subsubsection{Serum biochemistry evaluation}

The serum dosage was determined by automated chemical analyzer (Liasys, S.R.L. Analyzer Medical System ${ }^{\circledR}$, Assel, Italy) using specific commercial kits, according to the manufacturer's methodology. The levels of urea $(\mathrm{mg} / \mathrm{dL})$, creatinine ( $\mathrm{mg} / \mathrm{dL}$ ), total protein ( $T P$, in $\mathrm{g} / \mathrm{dL}$ ), albumin (ALB, in $\mathrm{g} / \mathrm{dL}$ ), glutamate-pyruvate transaminase/alanine aminotransferase (GPT/ALT, in U/L), glutamic-oxaloacetic transaminase/ Aspartate Aminotransferase (GOT/AST, in U/L) and alkaline phosphatase (AP, in $\mathrm{U} / \mathrm{L}$ ) were determined. The biochemical evaluation results obtained were compared to the reference values for canine species according to Kaneko et al. (1997).

\subsubsection{DNA extraction}

Total DNA molecules from approximately $30 \mathrm{mg}$ of popliteal lymph node fragments were extracted by Illustra ${ }^{\mathrm{TM}}$ tissue and cells genomic Prep Mini Spin Kit (GE Healthcare Europe $\mathrm{GmbH}$, Glattbrugg Switzerland) according to the manufacturer's instructions. DNA pellets were dissolved in ultra-pure water. DNA concentrations and purity were determined by the ratio of O.D. at 260 and $280 \mathrm{~nm}$ in a NanoDrop ND1000 spectrophotometer (Thermo Fisher Scientific, Waltham, MA, USA). 


\subsubsection{Conventional PCR}

Leishmania infantum infection in canine samples was confirmed by polimerase chain reaction (PCR) with specific primers RV1 (5'CTTTTCTGGTCCCGCGGGTAGG-3') and RV2 (5'CCACCTGGCCTATTTTACACCA-3'). This primer set amplifies specifically a 145-bp fragment of the variable region of the minicircle kDNA of $L$. donovani complex, and as far as we know, the only species from this complex that circulates in Brazil is $L$. infantum (Lachaud et al., 2002; le Fichoux et al., 1999). To check the success of DNA extraction control protocol the course of extraction and heck for PCR inhibitors, all canine samples were assayed using the interphotoreceptor retinoid-binding protein (IRBP) amplification based on highly conserved stretches within exon 1 of the canine gene sequence to amplify a 227-bp fragment (nucleotide positions 400-626, GeneBank accession DQ205906), with primers IRBP-CF-FWD (5'TCCAACACCACCACTGAGATCTGGAC-3') and IRBP-CF-REV (5'GTGAGGAAGAAATCGGACTGGCC-3') (Ferreira et al., 2010). Reactions were carried out with Go Taq Green Master Mix (Promega, Madison, WI, USA) containing 50 pmol of primers and $5 \mathrm{ul}$ of DNA in a final volume of $25 \mathrm{ul}$. The following amplification conditions were used: initial step of $95^{\circ} \mathrm{C}$ for $5 \mathrm{~min} ; 35$ cycles at $94^{\circ} \mathrm{C}$ for $30 \mathrm{~s}, 57^{\circ} \mathrm{C}$ (IRBP gene) or $60^{\circ} \mathrm{C}\left(\mathrm{L}\right.$. Infantum), $72^{\circ} \mathrm{C}$ for $1 \mathrm{~min}$ and then a final extension step at $72^{\circ} \mathrm{C}$ for $5 \mathrm{~min}$ in a thermocycler (Touchgene Gradiente, Techne, USA). PCR products were electrophoresed in $2 \%$ agarose gel, stained with GeIRed (Biotium, CA, USA) and visualized under UV illumination (Uvitec, Cambridge, UK). The negative control used was double-distilled water. DNA from L. infantum strain (MHOM/BR/1972 strain 46LD) were used as positive controls.

\subsubsection{Genetic analysis of the LinJ.31.2380 locus}

Two pairs of primers were designed for relative quantitative PCR (qPCR) to amplify a deletion site on LinJ.31.2380 locus (a putative responsible for encoding for $3^{\prime} \mathrm{NT} / \mathrm{NU}$ ) and a downstream region on chromosome 31 (LinJ.31.2330), used as a constitutive reference site (data and primers not yet published). The DNA of the nonDEL strain IOCL 2666 was used as a reference for relative quantification. A primer for a dog DNA target (HPRT - Hypoxanthine-guanine phosphoribosyltransferase) was 
also used to control sample quality and amplification. The standard protocol uses 0.2 nM of primers, 1x Sybr Green Master Mix, 40 cycles using $62^{\circ} \mathrm{C}$ as annealing temperature in an Applied Biosystems $₫ 7500$ Real-Time PCR Systems. Experiments were performed in triplicate techniques in two experimental replicates

\subsubsection{Determination of Parasite burden}

Parasite burdens were estimated by absolute qPCR in popliteal lymph nodes samples amplifying a single copy gene, the DNA polymerase gene. Primers and a probe described previously by Bretagne et al., 2001 and Mary et al., 2004 (TGTCGCTTGCAGACCAGATG [200 pmol], GCATCGCAGGTGTGAGCAC [200 pmol], and FAM-CCAGGCTCGAAGTTGTTGCTGCCC-MGB [200 pmol]). The expression of the canine housekeeping gene 18S rRNA was measured in order to normalize the concentration of input DNA for each sample and to obtain a reference amplification value to ensure the use of high-quality DNA samples (Rampazzo et al., 2017). TaqMan Pre-Developed Assay Reagents (Thermofisher Scientific, Waltham, MA) were used to detect and quantify both targets expression. All of the reactions were performed at a final volume of $25 \mu \mathrm{L}$ containing: $5 \mu \mathrm{L}$ of DNA canine tissue sample diluted in deionized water and $20 \mu \mathrm{L}$ of PCR mixture. The PCR mixture contained: 12.5 $\mu \mathrm{L}$ of Universal Mastermix (Thermofisher Scientific, Waltham, MA), 1.25 $\mu \mathrm{L}$ of $18 \mathrm{~S}$ GeneEx Assay and DNApol assay primer and probe sets (Thermofisher Scientific, Waltham, MA) at a concentration of $20 x$, and deionized water to obtain the final volume. The positive and negative controls were plated in triplicate and the samples were plated in duplicate for each target and both genes were run on the same plate for the same sample. Reactions were performed on a LightCycler $₫ 96$ Real-Time PCR System (Roche Life Science, Basel, Switzerland) using the following protocol: $1 \mathrm{cycle}$ at $50^{\circ} \mathrm{C}$ for $2 \mathrm{~min} ; 1 \mathrm{cycle}$ at $95^{\circ} \mathrm{C}$ for $10 \mathrm{~min}$; and 40 two-step cycles, first at $95^{\circ} \mathrm{C}$ for $15 \mathrm{~s}$ and then $60^{\circ} \mathrm{C}$ for $1 \mathrm{~min}$. A six-point standard curve for $18 \mathrm{~S}$ and DNApol genes were prepared using serial 10-fold dilutions from L. infantum strain (MHOM/BR/1972 strain 46LD) DNA extracted from $1 \times 10^{8}$ promastigotes and $6 \times 10^{7}$ Madin-Darby Canine Kidney (MDCK) line cells. Mean threshold cycle $(\mathrm{Ct})$ values were determined for technical duplicates. Ct values were plotted against input log-dilutions (base 10) and standard curves for each target determined by a linear regression, with the determined coefficients of determination (R2) used as quality control. Subsequently, 
the fitted standard curves were used to estimate overall number of parasites in the sample, while the host $18 \mathrm{~S}$ gene was used for canine cell number normalization. Thus, it was possible to obtain the number of parasites per $10^{6}$ cells. Amplification efficiency of each target was determined according to the equation: $E=10^{\wedge}(-1 /$ slope $)$. (Cavalcanti et al., 2015).

\subsubsection{Statistical analysis}

Statistical analysis was performed using $R$ statistical software ( $R$ Core Team (2015). R: A language and environment for statistical computing. R Foundation for Statistical Computing, Vienna, Austria. (https://www.r-project.org/) and Graph Pad Prism 4. Pearson's chi-square test and Fisher's exact test were used to evaluate frequencies. The continuous quantitative variables with abnormal distribution were presented in median and interquartile range. The normality of the variables was evaluated by Shapiro-Wilk's test. Repeated-measures analysis of variance (ANOVA) was used to compare parasite loads among all groups and individual evaluations were performed using the non-parametric Mann Whitney U-test. All analyses were two-tailed and pre-specified. Differences were considered to be statistically significant if the probability of a type I error was $<0.05$ ( $P$-values $<0.05)$.

\subsection{RESULTS}

\subsubsection{Frequency of the deletion on LinJ.31.2380 locus}

Among the 54 dogs in this study, 44.44\% (24/54) presented the deletion (DEL) in all the alleles on LinJ.31.2380 locus of chromosome 31 of L. infantum, while $35.19 \%$ $(19 / 54)$ revealed no deletion on this locus (NON-DEL) and 20.37\% (11/54) showed a mixed profile for the deleted site, representing heterozygosity or a mixed population of parasites. Eight samples demonstrated (14.81\%) an equivalent heterozygosity (HTZEQ) and three (5.56\%) were non-equivalent (HTZ-NEQ). 


\subsubsection{Diversity of the mutation on LinJ.31.2380 locus according to geographic regions}

Frequency of DEL in LinJ.31.2380 locus of chromosome 31 of $L$. infantum was assessed in distinct geographic areas of SP State. In two municipalities in southeast region of SP State (Embú and Itapira), the deletion was detected in $100 \%$ of cases, while none case of deletion was evidenced in the municipalities of Araçatuba, Jales and Santa Fé do Sul, located in northwest of SP State. The municipialities of Caieiras, Fernandopólis and Votuporanga showed $85.71 \%, 76.92 \%$ and $23.08 \%$, respectively of DEL samples and $14.29 \%, 15.38 \%$ and $38.46 \%$ of NON-DEL samples, respectively. Besides, equivalent heterozygosity was observed in $7.69 \%$ and $26.92 \%$ in samples from Fernandopólis and Votuporanga, respectively, and non-equivalent heterozygosity was detected in $11.54 \%$ of the samples in Votuporanga. Fisher-exact test results in a P-value $=0.01945$, showing a significant statistic difference between the mutation distribution in the different SP State municipalities (Fig. 1).

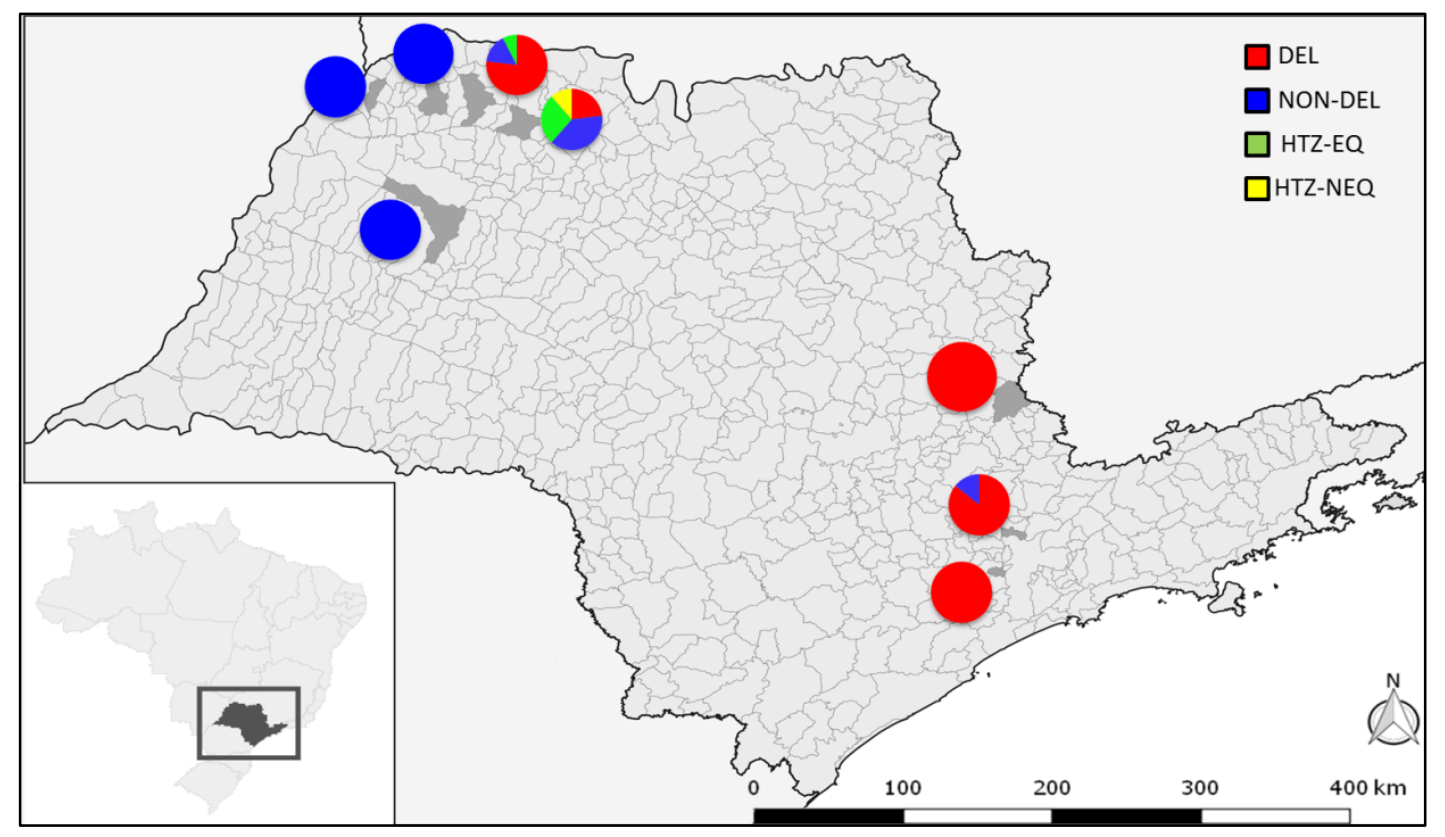

Fig 1. The geographic origin of Leishmania infantum samples and the distribution of allele frequencies in the population of SP state. DEL: deletion; NON-DEL: non-deletion; HTZ-EQ: equivalent heterozygosity; HTZ-NEQ: non-equivalent heterozygosity. 


\subsubsection{Diversity of the mutation on LinJ.31.2380 locus according to clinical evaluation}

Regarding the classification of the clinical stage of CVL, 19/24 (79.17\%), 3/24 $(12.50 \%)$ and $2 / 24(8.33 \%)$ of dogs infected with $L$. infantum presenting the DEL on LinJ.31.2380 locus of chromosome 31 were classified at clinical stage II, III and IV, respectively. While, NON-DEL L. infantum was detected in 14/19 (73.68\%), 3/19 (15.79\%), 2/19 (10.53\%) of animals classified in clinical stage II, III and IV, respectively. 8/8 (100.00\%) of HTZ-EQ samples were observed in dogs in clinical stage II. And finally, $2 / 3(66.67 \%)$ and $1 / 3(33.33 \%)$ of dogs infected with $L$. infantum presenting the HTZ-NEQ on LinJ.31.2380 locus of chromosome 31 were classified at clinical stage II and III (Table 1). There was no statistically significant difference between the status of the mutation on LinJ.31.2380 locus of $L$ infantum and the clinical stage of dogs affected $(p=0.7183)$.

Table 1. Distribution of the frequency of the mutation on LinJ.31.2380 locus of $L$ infantum according to the clinical stage.

\begin{tabular}{c|c|c|c|c}
\hline & \multicolumn{4}{|c}{ Clinical stage classification of leishmaniasis in dogs } \\
\hline & II & III & IV & Total \\
\hline DEL & $19(35.19 \%)$ & $3(5.56 \%)$ & $2(3.70 \%)$ & $24(44.44 \%)$ \\
\hline NON-DEL & $14(25.93 \%)$ & $3(5.56 \%)$ & $2(3.70 \%)$ & $19(35.19 \%)$ \\
\hline HTZ-EQ & $8(14.81 \%)$ & $0(0.00 \%)$ & $0(0.00 \%)$ & $8(14.81 \%)$ \\
\hline HTZ-NEQ & $2(3.70 \%)$ & $1(1.85 \%)$ & $0(0.00 \%)$ & $3(5.56 \%)$ \\
\hline TOTAL & $43(79.63 \%)$ & $7(12.96 \%)$ & $4(7.40 \%)$ & $54(100.0 \%)$ \\
\hline
\end{tabular}

\subsubsection{Association of the mutation on LinJ.31.2380 locus and parasite load}

The mean and standard error of the mean (SEM) of parasite load in the popliteal lymph node of samples were $5.17 \times 10^{5} \pm 2.14 \times 10^{5}$ for DEL on LinJ.31.2380 locus of L. infantum, $5.72 \times 10^{5} \pm 3.84 \times 10^{5}$ for NON-DEL group, $2.25 \times 10^{5} \pm 2.06 \times 10^{5}$ for HTZ-EQ and $7.14 \times 10^{5} \pm 7.10 \times 10^{5}$ for HTZ-NEQ. No significant statistical difference 
was observed between the groups $(p=0.913)$ through nonparametric one-way ANOVA (Fig. 2). Also, the analysis of the parasite load in the distinct clinical stage showed no statistical difference in stage II ( $p=0.777$, non-parametric ANOVA), III ( $p=0.567$, nonparametric ANOVA) and IV ( $p=1.000$, Mann-Whitney $U$ test) considering the specific genotypes on LinJ.31.2380 locus.

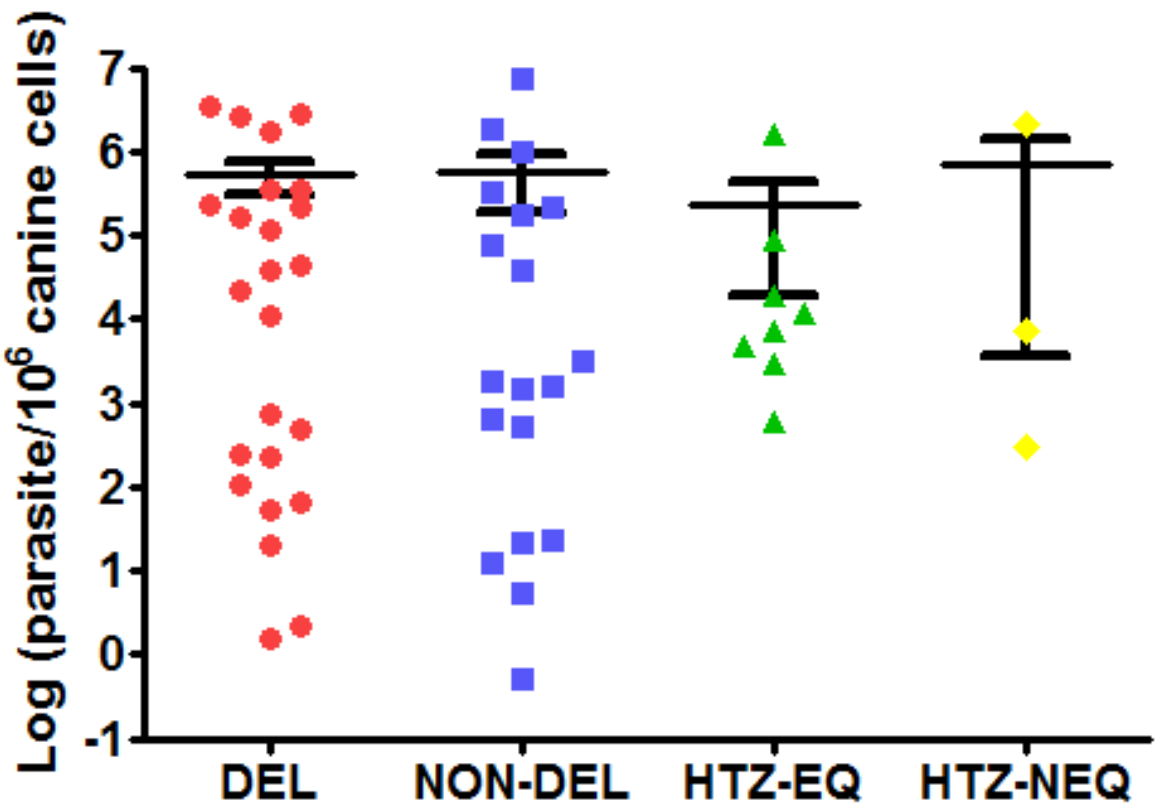

Fig. 2. Quantification of parasite load in popliteal lymph node samples from dogs naturally infected with CVL, according to mutation status on LinJ.31.2380 locus. Leishmania infantum parasite load expressed as the logarithm of the number of parasites in $10^{6}$ host cells. The horizontal bars indicate mean and standard error of the mean values. Statistical analysis (analysis of variance) shows no significant difference between the groups ( $p=0.913$, nonparametric one-way ANOVA).

\subsection{DISCUSSION}

This study provides new insights into aspects of the population genetics of $L$. infantum from Brazil and its relation to the eco-epidemiologic aspects of this parasite species in some of its endemic areas in the Americas. Cupolillo, E. performed a whole genome sequencing comparison of strains from Europe, North Africa, Brazil and other American countries, and detected a deletion at chromosome 31 corresponding to the ORF of a helicase, and two copies of 3'ecto-nucleotidase (3'NT/NU) in samples from 12 different Brazilian states, including SP state (personal communication). Indeed, the 
deletion was presented in $44.44 \%$ of the analyzed samples in this study. The fact that the region is deleted in all four stable homologs of chromosome 31 is a sign of a very strong purifying selection against this region - supporting the notion that the deletion is associated with a specific phenotype and was selected towards it (Ferreira et al., 2012). Also, a mixed profile for the deleted site, representing heterozygosity equivalent, with two chromosomes deleted and two non-deleted, and non-equivalent was also observed in $14,81 \%$ and $5,56 \%$, respectively, of the samples. Analysis of parasite culture is necessary to determine whether the heterogeneity resulted from loss of heterozygosity on some chromosomes in individual cells or whether the population was a mix of genotypes.

Cupolillo, E. also founded a strong signal of purifying selection after the mutation search in 120 samples in Brazil. DEL strains were more frequent and present a broad geographic distribution through the country, co-circulating with Non-DEL and HTZ strains in some areas. NonDEL and HTZ-EQ were detected only in Mato Grosso, Piauí, São Paulo and Santa Catarina (personal communication). In this study, we also identified NON-DEL, HTZ-EQ and NTZ-NEQ samples from SP state. The fact that the delete site on chromosome 31 is interesting because this is the only stable aneuploidy within the mosaic of aneuploidy cells that constitutes a Leishmania strain (Rogers et al., 2011; Sterkers et al., 2011). This mosaic pattern allows the parasite to use haplotype selection as an adaptive mechanism (Prieto Barja et al., 2017). In fact, clearly epidemiological patterns with this specific genetic marker among the regions of SP state were evidenced in this study. In the northwest (NWSP) region, that includes the municipalities of Araçatuba, Jales and Santa Fé do Sul, the NON-DEL profile was predominant in the samples. The exception was from the city of Votuporanga, in which DEL samples were the most frequent, as well as in the municipalities of the Southeast (SESP) of SP state (Caieirias, Embú and Itapira). These findings corroborated with the hypothesis that different routes of spread or transmission cycle could be related to $\mathrm{VL}$ in NWSP and SESP region of São Paulo state (Cardim et al., 2013; Motoie et al., 2013). Also, they coincided with the two distinct eco-epidemiological scenarios of the VL recognized in SP State. In the NWSP region, where the first autochthonous human cases were reported in Araçatuba in 1999, and since then, several other nearby municipalities have described a moderate to intense transmission of the parasite to humans and canines, besides the presence of the vector. And the other, in the SESP region of SP State, where low prevalence of CVL has been detected in municipalities 
since 2003, sometimes without identification of human cases and vectors (Motoie et al., 2013; Casanova et al., 2015; Cardim et al., 2016).

Trypanosome helicase functions may be associated with either RNA or DNA and have a role in unwinding the DNA during transcription initiation and/or elongation, and thus cell replication (Martinez-Calvillo e tal., 2007). The $3^{\prime} \mathrm{NT} / \mathrm{NU}$ is involved in the hydrolysis of both extracellular 3'-monophosphorylated nucleotides and nucleic acids providing an important source of adenosine via the hydrolysis of adenosine 3'monophosphate (3'-AMP) (Gottlieb, 1989). The generation of extracellular adenosine is also important to the modulation of the host immune response; assay with $L$. amazonensis showed that parasite-macrophage interaction is stimulated by the addition of adenosine or 3'-AMP (Freitas-Mesquita et al., 2016). Interaction assays involving Leishmania parasites and macrophages indicated that 3'-nucleotidase activity increases the association index between them (Freitas-Mesquita et al., 2016). The deletion, therefore, potentially affects parasite-host interaction.

Thus, we correlated this specific deletion genotype with clinical status and parasite load in popliteal lymph node samples of dogs naturally infected with $L$. infantum. However, no correlation of theses parameters with the deletion on LinJ.31.2380 locus was identified. None animals included in this study was classified in clinical stage I, characterized by negative to low positive antibody levels and mild clinical signs (papular dermatitis or single lymphadenopathy). Rather, they presented two or more clinical signs, low to high antibody levels and typical clinicopathological abnormalities of CVL, a more advanced stage of the disease. The 3'NT/NU is a key enzyme for the purine savage pathway (Sacci et al., 1990) and in the establishment of parasite infection in mammalian hosts (Guimarães-Costa et al., 2014; Vieira et al., 2011). This protein is more differently expressed during Leishmania amastigogenesis. Once, at the inoculation site in the vertebrate, $L$. infantum promastigotes can escape neutrophil extracellular traps (NETs)-mediated killing by 3'-nucleotidase/nuclease activity (Guimarães-Costa et al., 2014), one of the first mechanisms of the host immune system for preventing infection. It is also speculated that this enzyme has an impact on the parasite growth and virulence. Indeed, Boité, M.C. performed a 3'NU/NT enzymatic activity assay using four NonDEL and four DEL strains from different regions and confirmed that such genomic deletion has a negative effect on enzymatic activity, representing therefore a biological difference between samples that could affect parasite-host interaction (personal communication). The researches also 
demonstrated that DEL strains show increased colonization of the Lu. longipalpis midgut, infect less macrophages in vitro and survive less when in contact with neutrophil NET's in vitro. This result suggests the deletion is a marker of molecular pathways important for parasite's interaction with the invertebrate and vertebrate hosts, however, probably it has a greater influence in the initial establishment of the infection, and the animals evaluated in this study already had a persistent infection (Solano-Gallego et al., 2009).

Vertebrate and invertebrate hosts represent the environment to which Leishmania must adapt, and therefore represent the forces acting to select genotypes with greater fitness. This was a preliminary study considering the potential effect in parasite-host interaction due to the differences spotted in the 3'NU/NT activity. In addition, $L$. infantum isolates from Brazil, presenting a deletion that includes the same locus, were recently described and associated with miltefosine treatment failure for visceral leishmaniasis (Carnielli et al., 2018). The main limitation of our study is the lack of dogs in clinical stage I and the number of representative animals. However, serological negative dogs should not be reported to the local public health departments, even they have any mild clinical sign suspicion of CVL. PCR blood screening for direct identification of the parasite and genome-wide association studies of dogs naturally infected by the $L$. infatnum DEL, NonDEL, HTZ genotypes could establish other genotype-phenotype correlations.

In conclusion, naturally infected dogs from SP state represent an interesting scenario as all genotypes of $L$. infatum related to LinJ.31.2380 locus co-circulate in different eco-epidemiological scenarios, despite no correlation with clinical stage or parasite load were evidenced in lymph nodes samples.

\section{Funding}

This work was supported by Grant Program \#12/51267-4, São Paulo Research Foundation (FAPESP), Brazil; Grant Program for the Study of Neglected and Reemerging Diseases, process MCTI/CNPq/MS-SCTIE-Decit N ${ }^{\circ}$ 40/2012; and Projeto Universal CNPq, Brazil (grant number 459489/2014-3). 


\subsection{REFERENCES}

Brasil, Ministério da Saúde do. LEISHMANIOSE VISCERAL-Manual de Vigilância e Controle. Departamento de Vigilância Epidemiológica, Secretaria de Vigilância em Saúde. 2006: 122.

Bretagne, S., Durand, R., Olivi, M., Garin, J.F., Sulahian, A., Rivollet, D., Vidaud, M., Deniau, M., 2001. Real-time PCR as a new tool for quantifying Leishmania infantum in liver in infected mice. Clin. Diagn. Lab. Immunol. 8, 828-31. https://doi.org/10.1128/CDLI.8.4.828-831.2001

Burza, S., Croft, S.L., Boelaert, M., 2018. Leishmaniasis. Lancet 392, 951-970. https://doi.org/10.1016/S0140-6736(18)31204-2

Cardim, M.F.M., Guirado, M.M., Dibo, M.R., Chiaravalloti Neto, F., 2016. Visceral leishmaniasis in the state of Sao Paulo, Brazil: spatial and space-time analysis. Rev. Saude Publica 50. https://doi.org/10.1590/S1518-8787.2016050005965

Cardim, M.F.M., Rodas, L.A.C., Dibo, M.R., Guirado, M.M., Oliveira, A.M., Chiaravalloti Neto, F., 2013. Introducao e expansao da Leishmaniose visceral americana em humanos no estado de Sao Paulo, 1999-2011. Rev. Saude Publica 47, 691-700

Carnielli, J.B.T., Crouch, K., Forrester, S., Silva, V.C., Carvalho, S.F.G., Damasceno, J.D., Brown, E., Dickens, N.J., Costa, D.L., Costa, C.H.N., Dietze, R., Jeffares, D.C., Mottram, J.C., 2018. A Leishmania infantum genetic marker associated with miltefosine treatment failure for visceral leishmaniasis. EBioMedicine 36, 83-91. https://doi.org/10.1016/j.ebiom.2018.09.029.

Casanova, C., Colla-Jacques, F.E., Hamilton, J.G.C., Brazil, R.P., Shaw, J.J., 2015. Distribution of Lutzomyia longipalpis chemotype populations in São Paulo state, Brazil. PLoS Negl. Trop. Dis. 9, e0003620. https://doi.org/10.1371/journal.pntd.0003620

Cavalcanti, A.S., Ribeiro-Alves, M., Pereira, L. de O.R., Mestre, G.L., Ferreira, A.B.R., Morgado, F.N., Boité, M.C., Cupolillo, E., Moraes, M.O., Porrozzi, R., 2015. Parasite Load Induces Progressive Spleen Architecture Breakage and Impairs Cytokine mRNA Expression in Leishmania infantum-Naturally Infected Dogs. PLoS One 10, e0123009. https://doi.org/10.1371/journal.pone.0123009

Cupolillo, E., Brahim, L.R., Toaldo, C.B., de Oliveira-Neto, M.P., de Brito, M.E.F., Falqueto, A., de Farias Naiff, M., Grimaldi, G., 2003. Genetic polymorphism and molecular epidemiology of Leishmania (Viannia) braziliensis from different hosts and geographic areas in Brazil. J. Clin. Microbiol. 41, 3126-32.

Ferreira, G.E.M., dos Santos, B.N., Dorval, M.E.C., Ramos, T.P.B., Porrozzi, R., Peixoto, A.A., Cupolillo, E., 2012. The genetic structure of Leishmania infantum populations in Brazil and its possible association with the transmission cycle of $\begin{array}{lllll}\text { visceral } \quad \text { leishmaniasis. PLoS } & \text { One }\end{array}$ https://doi.org/10.1371/journal.pone.0036242

Ferreira, G.E.M., dos Santos, B.N., Dorval, M.E.C., Ramos, T.P.B., Porrozzi, R., Peixoto, A.A., Cupolillo, E., 2012. The genetic structure of Leishmania infantum populations in Brazil and its possible association with the transmission cycle of 
visceral leishmaniasis. PLoS One https://doi.org/10.1371/journal.pone.0036242

Freitas-Mesquita, A.L., Gomes, M.T., Vieira, D.P., Paes-Vieira, L., Nascimento, M.T.C., Lopes, A.H.C.S., Meyer-Fernandes, J.R., 2016. Inhibitory effects promoted by 5 '-nucleotides on the ecto-3'-nucleotidase activity of Leishmania amazonensis. Exp. Parasitol. 169, 111-118. https://doi.org/10.1016/j.exppara.2016.08.001

Freitas-Mesquita, A.L., Meyer-Fernandes, J.R., 2017. 3'nucleotidase/nuclease in protozoan parasites: Molecular and biochemical properties and physiological roles. Exp. Parasitol. 179, 1-6. https://doi.org/10.1016/j.exppara.2017.06.001

Gottlieb, M., 1989. The surface membrane 3'-nucleotidase/nuclease of trypanosomatid protozoa. Parasitol. Today 5, 257-60.

Guimarães-Costa, A.B., DeSouza-Vieira, T.S., Paletta-Silva, R., Freitas-Mesquita, A.L., Meyer-Fernandes, J.R., Saraiva, E.M., 2014. 3'-Nucleotidase/Nuclease Activity Allows Leishmania Parasites To Escape Killing by Neutrophil Extracellular Traps. Infect. Immun. 82, 1732-1740. https://doi.org/10.1128/IAl.01232-13

Guimarães-Costa, A.B., Nascimento, M.T.C., Froment, G.S., Soares, R.P.P., Morgado, F.N., Conceição-Silva, F., Saraiva, E.M., 2009. Leishmania amazonensis promastigotes induce and are killed by neutrophil extracellular traps. Proc. Natl. Acad. Sci. U. S. A. 106, 6748-53. https://doi.org/10.1073/pnas.0900226106

Ishikawa, E.A.Y., Silveira, F.T., Magalhães, A.L.P., Guerra, R.B., Melo, M.N., Gomes, R., Silveira, T.G.V., Shaw, J.J., 2002. Genetic variation in populations of Leishmania species in Brazil. Trans. R. Soc. Trop. Med. Hyg. 96, S111-S121. https://doi.org/10.1016/S0035-9203(02)90061-1

Kaneko JJ, Harvey JW, Bruss ML. Appendixes. In: Kaneko JJ, Harvey JW, Bruss ML. Clinical biochemistry of domestic animals. 5th ed. New York: Academic Press; 1997. p. 885-906. http://dx.doi.org/10.1016/ B978-012396305-5/50032-4

Kuhls, K., Keilonat, L., Ochsenreither, S., Schaar, M., Schweynoch, C., Presber, W., Schönian, G., 2007. Multilocus microsatellite typing (MLMT) reveals genetically isolated populations between and within the main endemic regions of visceral $\begin{array}{llll}\text { leishmaniasis. Microbes Infect. } & \text { 334-43. }\end{array}$ https://doi.org/10.1016/i.micinf.2006.12.009

Lachaud, L., Marchergui-Hammami, S., Chabbert, E., Dereure, J., Dedet, J.P., Bastien, P., 2002. Comparison of six PCR methods using peripheral blood for detection of canine visceral leishmaniasis. J. Clin. Microbiol. 40, 210-5. https://doi.org/10.1128/JCM.40.1.210-215.2002

le Fichoux, Y., Quaranta, J.F., Aufeuvre, J.P., Lelievre, A., Marty, P., Suffia, I., Rousseau, D., Kubar, J., 1999. Occurrence of Leishmania infantum parasitemia in asymptomatic blood donors living in an area of endemicity in southern France. J. Clin. Microbiol. 37, 1953-7.

Martínez-Calvillo, S., Saxena, A., Green, A., Leland, A., Myler, P.J., 2007. Characterization of the RNA polymerase II and III complexes in Leishmania major. Int. J. Parasitol. 37, 491-502. https://doi.org/10.1016/j.ijpara.2006.11.019 
Mary, C., Faraut, F., Lascombe, L., Dumon, H., 2004. Quantification of Leishmania infantum DNA by a real-time PCR assay with high sensitivity. J. Clin. Microbiol. 42, 5249-55. https://doi.org/10.1128/JCM.42.11.5249-5255.2004

Molina, R., Jiménez, M.I., Cruz, I., Iriso, A., Martín-Martín, I., Sevillano, O., Melero, S., Bernal, J., 2012. The hare (Lepus granatensis) as potential sylvatic reservoir of Leishmania infantum in Spain. Vet. Parasitol. 190, 268-71. https://doi.org/10.1016/j.vetpar.2012.05.006

Moreno, J., Alvar, J., 2002. Canine leishmaniasis: epidemiological risk and the experimental model. Trends Parasitol. 18, 399-405.

Motoie, G., Ferreira, G.E.M., Cupolillo, E., Canavez, F., Pereira-Chioccola, V.L., 2013. Spatial distribution and population genetics of Leishmania infantum genotypes in São Paulo State, Brazil, employing multilocus microsatellite typing directly in dog infected tissues. Infect. Genet. Evol. 18, 48-59. https://doi.org/10.1016/j.meegid.2013.04.031

Ochsenreither, S., Kuhls, K., Schaar, M., Presber, W., Schonian, G., Schönian, G., 2006. Multilocus microsatellite typing as a new tool for discrimination of Leishmania infantum MON-1 strains. J. Clin. Microbiol. 44, 495-503. https://doi.org/10.1128/JCM.44.2.495-503.2006

PAHO, Pan American Health Organization: Leishmaniasis: Epidemiological Report in the Americas: Washington: Pan American Health Organization; 2018. Available at: www.paho.org/leishmaniasis.

Prieto Barja, P., Pescher, P., Bussotti, G., Dumetz, F., Imamura, H., Kedra, D., Domagalska, M., Chaumeau, V., Himmelbauer, H., Pages, M., Sterkers, Y., Dujardin, J.-C., Notredame, C., Späth, G.F., 2017. Haplotype selection as an adaptive mechanism in the protozoan pathogen Leishmania donovani. Nat. Ecol. Evol. 1, 1961-1969. https://doi.org/10.1038/s41559-017-0361-x

Rampazzo, R. de C.P., Solcà, M. da S., Santos, L.C.S., Pereira, L. de N., Guedes, J.C.O., Veras, P.S.T., Fraga, D.B.M., Krieger, M.A., Costa, A.D.T., 2017. A readyto-use duplex qPCR to detect Leishmania infantum DNA in naturally infected dogs. Vet. Parasitol. 246, 100-107. https://doi.org/10.1016/j.vetpar.2017.09.009

Reis, A.B., Martins-Filho, O.A., Teixeira-Carvalho, A., Giunchetti, R.C., Carneiro, C.M., Mayrink, W., Tafuri, W.L., Corrêa-Oliveira, R., 2009. Systemic and compartmentalized immune response in canine visceral leishmaniasis. Vet. Immunol. Immunopathol. 128, 87-95. https://doi.org/10.1016/j.vetimm.2008.10.307

Ribeiro, R.R., Michalick, M.S.M., da Silva, M.E., Dos Santos, C.C.P., Frézard, F.J.G., da Silva, S.M., 2018. Canine Leishmaniasis: An Overview of the Current Status and Strategies for Control. Biomed Res. Int. 2018, 3296893. https://doi.org/10.1155/2018/3296893

Rogers, M.B., Hilley, J.D., Dickens, N.J., Wilkes, J., Bates, P.A., Depledge, D.P., Harris, D., Her, Y., Herzyk, P., Imamura, H., Otto, T.D., Sanders, M., Seeger, K., Dujardin, J.-C., Berriman, M., Smith, D.F., Hertz-Fowler, C., Mottram, J.C., 2011. Chromosome and gene copy number variation allow major structural change between species and strains of Leishmania. Genome Res. 21, 2129-42. https://doi.org/10.1101/gr.122945.111 
Sacci, J.B., Campbell, T.A., Gottlieb, M., 1990. Leishmania donovani: regulated changes in the level of expression of the surface 3'-nucleotidase/nuclease. Exp. Parasitol. 71, 158-68.

Saporito, L., Giammanco, G.M., De Grazia, S., Colomba, C., 2013. Visceral leishmaniasis: host-parasite interactions and clinical presentation in the immunocompetent and in the immunocompromised host. Int. J. Infect. Dis. 17, e572-e576. https://doi.org/10.1016/j.ijid.2012.12.024

Solano-Gallego, L., Koutinas, A., Miró, G., Cardoso, L., Pennisi, M.G., Ferrer, L., Bourdeau, P., Oliva, G., Baneth, G., 2009. Directions for the diagnosis, clinical staging, treatment and prevention of canine leishmaniosis. Vet. Parasitol. 165, 118. https://doi.org/10.1016/j.vetpar.2009.05.022

Sterkers, Y., Lachaud, L., Crobu, L., Bastien, P., Pagès, M., 2011. FISH analysis reveals aneuploidy and continual generation of chromosomal mosaicism in Leishmania major. Cell. Microbiol. 13, 274-83. https://doi.org/10.1111/j.1462$\underline{\text { 5822.2010.01534.x }}$ 


\section{GENERAL CONCLUSIONS}

The present study validated and implemented new cytopathological techniques for the diagnosis of CVL. This is the first study that applied LBC for the diagnosis of CVL. LBC reduced the number of unsatisfactory cases, allowed an excellent cellular preservation and the application of ancillary techniques, such as CB and ICC. CB-ICC alone or associated with $\mathrm{SC}$ demonstrated significantly higher sensitivity when compared to the SC alone. CB-ICC showed to be more effective in the detection of infected animals with mild clinical signs, similar to FFPE-IHC. Also, the detection limit for CB-ICC and SC+CB-ICC was identical. Therefore, CB-ICC seems to be a promising tool and may be applied in the algorithm for the diagnosis of the first autochthonous case of CLV in the municipalities of SP state into the VL Control and Surveillance Program of the Brazilian Ministry of Health.

Regarding parasite-host interaction, we also evaluated host and parasite characteristics through histopathological, cytokine profile, parasite load and a specific L. infantum genotype marker in lymph nodes of dogs naturally infected with Leishmania infantum from different eco-epidemiological scenarios. For the first time, differences among vertebrate hosts were evidenced in the northwestern (NWSP) and southeastern (SESP) geographic areas of SP State. A marked subcapsular inflammatory infiltration and histiocytosis predominated in animals from SESP. Otherwise, dogs from NWSP revealed significantly higher parasite burden and IHC scores of IL-1 $\beta$ and IL-4.

The deletion genotype of $L$. infatum on LinJ.31.2380 locus was predominantly identified in the SESP population, while the non-deletion genotype was observed in the NWSP municipalities, with a statistically significant difference. A third, mixed profile for the deleted site, representing heterozygosity equivalent and non-equivalent, were also described, predominantly in NWSP samples. No statistical difference was observed between the specific genotype and the clinical status and the parasite density in the popliteal lymph node samples of the dogs. All these data together contributed to the detection of the genetic profile of $L$. infantum population and the epidemiology of CVL in SP state. However, this specific genotype marker seems not to be the only factor related to the evident differences among the infected dogs. Further investigations could focus on other immunogenetic markers in vertebrates host that 
correlate to the specific deletion on LinJ.31.2380 locus or to the distinct ecoepidemiological scenarios through genome wide association scan.

Therefore, differences in genetic profile of $L$. infantum population and in immune response associated with higher parasite burden in dogs can also contribute to explain the distinct eco-epidemiological patterns of VL in specific geographic regions, which requires the development of better control and surveillance strategies to improve both public and animal health. 


\section{REFERENCES}

AFONSO, L. et al. Interactions with apoptotic but not with necrotic neutrophils increase parasite burden in human macrophages infected with Leishmania amazonensis. Journal of leukocyte biology, v. 84, n. 2, p. 389-396, 2008.

AGUIRRE, A. A. Wild canids as sentinels of ecological health: a conservation medicine perspective. Parasites \& Vectors, v. 2, n. Suppl 1, p. S7, 2009.

AKHOUNDI, M. et al. A Historical Overview of the Classification, Evolution, and Dispersion of Leishmania Parasites and Sandflies. PLOS Neglected Tropical Diseases, v. 10, n. 3, p. e0004349, 2016.

AKOPYANTS, N. S. et al. Demonstration of genetic exchange during cyclical development of Leishmania in the sand fly vector. Science (New York, N.Y.), v. 324, n. 5924, p. 265-268, 2009.

ALAM, M. Z. et al. Multilocus microsatellite typing (MLMT) reveals genetic homogeneity of Leishmania donovani strains in the Indian subcontinent. Infection, genetics and evolution : journal of molecular epidemiology and evolutionary genetics in infectious diseases, v. 9, n. 1, p. 24-31, 2009.

ALCOLEA, P. J. et al. Stage-specific differential gene expression in Leishmania infantum: from the foregut of Phlebotomus perniciosus to the human phagocyte. BMC genomics, v. 15, p. 849, 2014.

ALENCAR J.E.; DIETZE R. Leishmaniose visceral (calazar). In: VERONESI R. Doenças infecciosas e parasitárias. Rio de Janeiro: Editora Guanabara Koogan, 1991. p. 706-717.

ALENCAR J.E. Expansão do Calazar no Brasil. Ceará Médico, v. 5, p. 86-102, 1983.

ALEXANDRE-PIRES, G. et al. Canine leishmaniasis. Immunophenotypic profile of leukocytes in different compartments of symptomatic, asymptomatic and treated dogs. Veterinary immunology and immunopathology, v. 137, n. 3-4, p. 275-283, 2010.

ALMEIDA, M. A. O. et al. Clinical and serological aspects of visceral leishmaniasis in northeast Brazilian dogs naturally infected with Leishmania chagasi. Veterinary parasitology, v. 127, n. 3-4, p. 227-232, 2005. 
ALVAR, J. et al. Canine leishmaniasis. Advances in parasitology, v. 57, p. 1-88, 2004.

ALVAR, J. et al. The relationship between leishmaniasis and AIDS: the second 10 years. Clinical microbiology reviews, v. 21, n. 2, p. 334-359, table of contents, 2008.

ALVAR, J. et al. Leishmaniasis Worldwide and Global Estimates of Its Incidence. PLoS ONE, v. 7, n. 5, p. e35671, 2012.

ALVES, C. F. et al. Expression of IFN-gamma, TNF-alpha, IL-10 and TGF-beta in lymph nodes associates with parasite load and clinical form of disease in dogs naturally infected with Leishmania (Leishmania) chagasi. Veterinary immunology and immunopathology, v. 128, n. 4, p. 349-358, 2009.

ALVES, M. J. et al. Visceral leishmaniasis: situation diagnosis from the perspective of disease control in Brazil. Journal of Microbiology \& Experimentation, v. 6, n. 2, p. 104-106, 2018.

ANTINORI, S. et al. Clinical Use of Polymerase Chain Reaction Performed on Peripheral Blood and Bone Marrow Samples for the Diagnosis and Monitoring of Visceral Leishmaniasis in HIV-Infected and HIV-Uninfected Patients: A SingleCenter, 8-Year Experience in Italy and Review. Clinical Infectious Diseases, v. 44, n. 12, p. 1602-1610, 2007.

ANTONIOU, M. et al. The role of indigenous phlebotomine sandflies and mammals in the spreading of leishmaniasis agents in the Mediterranean region. Euro surveillance : bulletin Europeen sur les maladies transmissibles $=$ European communicable disease bulletin, v. 18, n. 30, p. 20540, 2013.

APHASIZHEV, R.; APHASIZHEVA, I. Uridine insertion/deletion editing in trypanosomes: a playground for RNA-guided information transfer. Wiley Interdisciplinary Reviews: RNA, v. 2, n. 5, p. 669-685, 2011.

ARAKI, A. S. et al. Molecular and Behavioral Differentiation among Brazilian Populations of Lutzomyia longipalpis (Diptera: Psychodidae: Phlebotominae). PLoS Neglected Tropical Diseases, v. 3, n. 1, p. e365, 2009.

ARESU, L. et al. Light and electron microscopic analysis of consecutive renal biopsy specimens from leishmania-seropositive dogs. Veterinary pathology, v. 50, n. 5, p. 753-760, 2013.

ASHFORD, R. W. The leishmaniases as emerging and reemerging zoonoses. 
International journal for parasitology, v. 30, n. 12-13, p. 1269-81, 2000.

BADARÓ, R.; DUARTE, M. I. S. Leishmaniose Visceral (Calazar). In: VERONESE, R.; FOCACCl, R. Tratado de Infectologia. São Paulo: Atheneu, v. 2, p.1234- 1259, 1996.

BALLOUX, F.; LEHMANN, L.; DE MEEÛS, T. The population genetics of clonal and partially clonal diploids. Genetics, v. 164, n. 4, p. 1635-1644, 2003.

BANETH, G. et al. Canine leishmaniosis - new concepts and insights on an expanding zoonosis: part one. Trends in parasitology, v. 24, n. 7, p. 324-330, 2008.

BAÑULS, A.-L.; HIDE, M.; PRUGNOLLE, F. Leishmania and the leishmaniases: a parasite genetic update and advances in taxonomy, epidemiology and pathogenicity in humans. Advances in parasitology, v. 64, p. 1-109, 2007.

BAÑULS, A.-L.; HIDE, M.; TIBAYRENC, M. Evolutionary genetics and molecular diagnosis of Leishmania species. Transactions of the Royal Society of Tropical Medicine and Hygiene, v. 96, p. S9-S13, 2002.

BANŨLS, A. L.; HIDE, M.; TIBAYRENC, M. Molecular epidemiology and evolutionary genetics of Leischmania parasites. International journal for parasitology, v. 29, n. 8, p. 1137-1147, 1999.

BARBOSA, M. A. G. et al. Cytokine Gene Expression in the Tissues of Dogs Infected by Leishmania infantum. Journal of Comparative Pathology, v. 145, n. 4, p. 336344, 2011.

BARROUIN-MELO, S. M. et al. Comparison between splenic and lymph node aspirations as sampling methods for the parasitological detection of Leishmania chagasi infection in dogs. Memórias do Instituto Oswaldo Cruz, v. 99, n. 2, p. 195197, 2004.

BASTIEN, P.; PROCOP, G. W.; REISCHL, U. Quantitative real-time PCR is not more sensitive than "conventional" PCR. Journal of clinical microbiology, v. 46, n. 6, p. 1897-1900, 2008.

BATES, P. A. Transmission of Leishmania metacyclic promastigotes by phlebotomine sand flies. International Journal for Parasitology, v. 37, n. 10, p. 1097-1106, 2007. 
BATISTA, L. F. DA S. et al. An assessment of the genetic diversity of Leishmania infantum isolates from infected dogs in Brazil. The American journal of tropical medicine and hygiene, v. 86, n. 5, p. 799-806, 2012.

BAUZER, L. G. S. R. et al. The period gene and genetic differentiation between three Brazilian populations of Lutzomyia longipalpis. Insect molecular biology, v. 11, n. 4, p. 315-323, 2002.

BAUZER, L. G. S. R. et al. Lutzomyia longipalpis in Brazil: a complex or a single species? A mini-review. Memorias do Instituto Oswaldo Cruz, v. 102, n. 1, p. 1-12, 2007.

BECK, A. et al. A case of visceral leishmaniosis in a gray wolf (Canis lupus) from Croatia. Journal of wildlife diseases, v. 44, n. 2, p. 451-456, 2008.

BEJARANO, E. E. et al. Presence of Lutzomyia evansi, a vector of American visceral leishmaniasis, in an urban area of the Colombian Caribbean coast. Transactions of the Royal Society of Tropical Medicine and Hygiene, v. 95, n. 1, p. 27-28, 2001.

BELLI, A. A.; MILES, M. A.; KELLY, J. M. A putative Leishmania panamensis/ Leishmania braziliensis hybrid is a causative agent of human cutaneous leishmaniasis in Nicaragua. Parasitology, v. 109 ( Pt 4, p. 435-442, 1994.

BERN, C.; MAGUIRE, J. H.; ALVAR, J. Complexities of assessing the disease burden attributable to leishmaniasis. PLoS neglected tropical diseases, v. 2, n. 10, p. e313, 2008.

BEVILACQUA, P. D. et al. Urbanização da leishmaniose visceral em Belo Horizonte. Arquivo Brasileiro de Medicina Veterinária e Zootecnia, v. 53, n. 1, p. 1-8, 2001.

BIRKENHEUER, A. J. et al. Babesia gibsoni infections in dogs from North Carolina. Journal of the American Animal Hospital Association, v. 35, n. 2, p. 125-128, 1999.

BOGGIATTO, P. M. et al. Immunologic indicators of clinical progression during canine Leishmania infantum infection. Clinical and vaccine immunology : CVI, v. 17 , n. 2, p. 267-273, 2010.

BRASIL, M.S.. Secretaria de Vigilância em Saúde. Departamento de Vigilância Epidemiológica. Manual de vigilância e controle da leishmaniose visceral / Ministério da Saúde, Secretaria de Vigilância em Saúde, Departamento de Vigilância Epidemiológica. - Brasília: Editora do Ministério da Saúde, 2006. 120 p.: il. color (Série A. Normas e Manuais Técnicos). 
BRASIL, M.S. Distribuição do número de casos e óbitos de LVA segundo município e GVE de infecção. Estado de São Paulo, 2010 a 2013. In: Centro de Vigilância Epidemiológica do Estado de São Paulo [Internet]. 2015. http://www.cve.saude.sp.gov.br/htm/zoo/lvah_lpi.htm

BRASIL, M.S. Distribuição do número de casos e óbitos de LVA segundo município e GVE de infecção. Estado de São Paulo, 1999 a 2009. In: Centro de Vigilância Epidemiológica do Estado de São Paulo [Internet]. 2013. http://www.cve.saude.sp.gov.br/htm/zoo/lvah9909_lpi.htm

BRASIL, M.S.. Secretaria de Vigilância em Saúde. Departamento de Vigilância Epidemiológica. Leishmaniose visceral 2017/ Ministério da Saúde. In: Secretaria de Vigilância em Saúde, Departamento de Vigilância Epidemiológica. - Brasília [Internet]. 2017. Acesso em: 23 Mar 2019. Disponível em: $<$ http://portalarquivos2.saude.gov.br/images/pdf/2019/janeiro/28/leishvisceral-17novo-layout.pdf>

BRETAGNE, S. et al. Real-time PCR as a new tool for quantifying Leishmania infantum in liver in infected mice. Clinical and diagnostic laboratory immunology, v. 8 , n. 4 , p. 828-831, 2001.

BURZA, S.; CROFT, S. L.; BOELAERT, M. Leishmaniasis. The Lancet, v. 392, n. 10151, p. 951-970, 2018.

CAMARGO-NEVES, V. L. F. DE; SPÍNOLA, R.; LAGE, L. A Leishmaniose Visceral Americana no estado de São Paulo: situação epidemiológica em 2001-2002.

Revista da Sociedade Brasileira de Medicina Tropical, v. 36, n. suppl 2, p. 27-29, 2003.

CAMARGO-NEVES, V. L. F. e Grupo de Estudos em leishmanioses. Classificação epidemiológica dos municípios para a leishmaniose visceral americana. Boletim Epidememiológico Paulista [Boletim on line], v. 39, p. 27-39, 2007. Disponível em: <http://www.cve.saude.sp.gov.br> acesso em: 18.11.2018

CAMARGO, L. B.; LANGONI, H. Impact of leishmaniasis on public health. Journal of Venomous Animals and Toxins including Tropical Diseases, v. 12, n. 4, p. 527548, 2006.

CAMUSSI, G. et al. Tumor necrosis factor/cachectin stimulates peritoneal macrophages, polymorphonuclear neutrophils, and vascular endothelial cells to synthesize and release platelet-activating factor. The Journal of experimental medicine, v. 166, n. 5, p. 1390-1404, 1987.

CARDIM, M. F. M. et al. Introducao e expansao da Leishmaniose visceral americana 
em humanos no estado de Sao Paulo, 1999-2011. Revista de Saúde Pública, v. 47, n. 4, p. 691-700, 2013.

CARDIM, M. F. M. et al. Visceral leishmaniasis in the state of Sao Paulo, Brazil: spatial and space-time analysis. Revista de Saúde Pública, v. 50, 2016.

CARRILLO, J. et al. Visceral leishmaniasis in Costa Rica: first case report. Clinical infectious diseases : an official publication of the Infectious Diseases Society of America, v. 29, n. 3, p. 678-679, 1999.

CASANOVA, C. et al. Identification of sex pheromones of Lutzomyia longipalpis (Lutz Neiva, 1912) populations from the state of São Paulo, Brazil. Memórias do Instituto Oswaldo Cruz, v. 101, n. 1, p. 113-115, 2006.

CASANOVA, C. et al. Distribution of Lutzomyia longipalpis chemotype populations in São Paulo state, Brazil. PLoS neglected tropical diseases, v. 9, n. 3, p. e0003620, 2015.

CASTAGNARO, M.; CROTTI, A.; FONDATI, A.; GRADONI, L.; LUBAS, G.; MAROLI, M.; OLIVA, G.; PALTRINIERI, S.; SOLANO-GALLEGO, L.; ROURA, X.; ZATELLI, A.; ZINI, E. Canine leishmaniasis: guidelines for diagnosis, staging, therapy, monitoring and prevention. In: CANINE LEISHMANIASIS WORKING GROUP. Italy: Hill's Italia, 2007.

CHAGAS E., CHAGAS A. W. Notas sobre a epidemiologia da leishmaniose visceral americana no Mato Grosso. O Hospital, v. 13, p. 471-480, 1938.

CHAPMAN, L. A. C. et al. Quantification of the natural history of visceral leishmaniasis and consequences for control. Parasites \& vectors, v. 8, p. 521, 2015.

CHAPPUIS, F. et al. Visceral leishmaniasis: what are the needs for diagnosis, treatment and control? Nature reviews. Microbiology, v. 5, n. 11, p. 873-882, 2007.

CHARMOY, M. et al. The NIrp3 inflammasome, IL-1 $\beta$, and neutrophil recruitment are required for susceptibility to a nonhealing strain of Leishmania major in C57BL/6 mice. European journal of immunology, v. 46, n. 4, p. 897-911, abr. 2016.

CHARMOY, M. et al. Leishmania major induces distinct neutrophil phenotypes in mice that are resistant or susceptible to infection. Journal of leukocyte biology, v. 82, n. 2, p. 288-299, 2007. 
$\mathrm{CHICHARRO}$, C. et al. Molecular epidemiology of Leishmania infantum on the island of Majorca: a comparison of phenotypic and genotypic tools. Transactions of the Royal Society of Tropical Medicine and Hygiene, v. 96 Suppl 1, p. S93-S99, 2002.

CIARAMELLA, P. et al. A retrospective clinical study of canine leishmaniasis in 150 dogs naturally infected by Leishmania infantum. The Veterinary record, v. 141, n. 21, p. 539-543, 22,1997.

CIARAVOLO, R. M. C. et al. Epidemiological classification of cities according to the program of surveillance and control of visceral leishmaniasis in the State of São Paulo, Updated in December 2014. Boletim Epidemiológico Paulista, v. 12, n. 143, p. 9-22, 2015.

COLOMBO, F. A. et al. Detection of Leishmania (Leishmania) infantum RNA in fleas and ticks collected from naturally infected dogs. Parasitology Research, v. 109, n. 2, p. 267-274, 2011.

COLOMBO, S. et al. Pustular dermatitis in dogs affected by leishmaniosis: 22 cases. Veterinary dermatology, v. 27, n. 1, p. 9-e4, 2016.

CORREA ANTONIALLI, S. A. et al. Spatial analysis of American Visceral Leishmaniasis in Mato Grosso do Sul State, Central Brazil. Journal of Infection, v. 54, n. 5, p. 509-514, 2007.

CORTESE, L. et al. Prevalence of anti-platelet antibodies in dogs naturally coinfected by Leishmania infantum and Ehrlichia canis. The Veterinary Journal, v. 188, n. 1, p. 118-121, 2011.

COSTA, C. H. N.; PEREIRA, H. F.; ARAÚJO, M. V. Epidemia de leishmaniose visceral no Estado do Piauí, Brasil, 1980-1986. Revista de Saúde Pública, v. 24, n. 5, p. 361-372, 1990.

COSTA, T. A. C. et al. Ocorrência de leishmaniose em gatos de área endêmica para leishmaniose visceral. Brazilian Journal of Veterinary Research and Animal Science, v. 47, n. 3, p. 213-217, 2010.

COURA-VITAL, W. et al. Prevalence and Factors Associated with Leishmania infantum Infection of Dogs from an Urban Area of Brazil as Identified by Molecular Methods. PLoS Neglected Tropical Diseases, v. 5, n. 8, p. e1291, 2011.

COUTINHO, M. T. Z. et al. Participation of Rhipicephalus sanguineus (Acari: Ixodidae) in the epidemiology of canine visceral leishmaniasis. Veterinary parasitology, v. 128, n. 1-2, p. 149-155, 2005. 
CVE, CENTRO DE VIGILÂNCIA EPIDEMIOLÓGICA DO ESTADO DE SÃO PAULO, 2018. Casos confirmados de Leishmaniose Visceral segundo LPI e ano de notificação, Estado de São Paulo, 2014 a 2018.

<http://www.saude.sp.gov.br/resources/cve-centro-de-vigilanciaepidemiologica/areas-de-vigilancia/doencas-de-transmissao-por-vetores-ezoonoses/dados/leish/lv1418_lpi.pdf > Acesso em: 18.01.2019.

DA SILVA, E. S. et al. Diagnosis of canine leishmaniasis in the endemic area of Belo Horizonte, Minas Gerais, Brazil by parasite, antibody and DNA detection assays. Veterinary research communications, v. 30, n. 6, p. 637-643, 2006.

DABAGHMANESH, T. et al. Natural transovarial and transstadial transmission of Leishmania infantum by naïve Rhipicephalus sanguineus ticks blood feeding on an endemically infected dog in Shiraz, south of Iran. Transactions of the Royal Society of Tropical Medicine and Hygiene, v. 110, n. 7, 2016.

DANTAS-TORRES, F. Leishmania infantum versus Leishmania chagasi: do not forget the law of priority. Memórias do Instituto Oswaldo Cruz, v. 101, n. 1, p. 117118, 2006a.

DANTAS-TORRES, F. Final comments on an interesting taxonomic dilemma: Leishmania infantum versus Leishmania infantum chagasi. Memórias do Instituto Oswaldo Cruz, v. 101, n. 8, p. 929-930, 2006b.

DANTAS-TORRES, F. The brown dog tick, Rhipicephalus sanguineus (Latreille, 1806) (Acari: Ixodidae): From taxonomy to control. Veterinary Parasitology, v. 152, n. 3-4, p. 173-185, 2008.

DE ALENCAR, J. E. [Visceral Leishmaniasis in Brazil]. Revista da Associacao Medica Brasileira, v. 4, n. 3, p. 222-236, 1958.

DE ALENCAR, J. E.; HOLANDA, D.; CAVALCANTE, J. D. [Kala azar in the valley of the Jaguaribe river, Ceara, 1955]. Revista brasileira de malariologia e doencas tropicais. Publicacoes avulsas, v. 8, n. 1, p. 33-47, 1956.

DE ALMEIDA, M. E. et al. Identification of Leishmania spp. by molecular amplification and DNA sequencing analysis of a fragment of rRNA internal transcribed spacer 2. Journal of clinical microbiology, v. 49, n. 9, p. 3143-3149, 2011.

DEANE, M.P.; DEANE, L.M. Observações sobre a transmissão da leishmaniose visceral no Ceará. Hospital, Rio de Janeiro, v. 48, p. 347-364, 1955.

DE ARAÚJO, V. A. L. et al. Mixed infection in the anteater Tamandua tetradactyla 
(Mammalia: Pilosa) from Pará State, Brazil: Trypanosoma cruzi, T. rangeli and Leishmania infantum. Parasitology, v. 140, n. 04, p. 455-460, 2013.

DE ARAÚJO, V. E. M. et al. Early clinical manifestations associated with death from visceral leishmaniasis. PLoS neglected tropical diseases, v. 6, n. 2, p. e1511, 2012.

DE CARVALHO, M. R. et al. Natural Leishmania infantum infection in Migonemyia migonei (França, 1920) (Diptera:Psychodidae:Phlebotominae) the putative vector of visceral leishmaniasis in Pernambuco State, Brazil. Acta tropica, v. 116, n. 1, p. 108, 2010.

DE FREITAS, E. et al. Transmission of Leishmania infantum via blood transfusion in dogs: potential for infection and importance of clinical factors. Veterinary parasitology, v. 137, n. 1-2, p. 159-167, 2006.

DE OLIVEIRA, J. et al. Genetic diversity of Leishmania amazonensis strains isolated in northeastern Brazil as revealed by DNA sequencing, PCR-based analyses and molecular karyotyping. Kinetoplastid Biology and Disease, v. 6, n. 1, p. 5, 2007.

DE PITA-PEREIRA, D. et al. Detection of natural infection in Lutzomyia cruzi and Lutzomyia forattinii (Diptera: Psychodidae: Phlebotominae) by Leishmania infantum chagasi in an endemic area of visceral leishmaniasis in Brazil using a PCR multiplex assay. Acta Tropica, v. 107, n. 1, p. 66-69, 2008.

DE SOUZA CARMO, E. V.; KATZ, S.; BARBIÉRI, C. L. Neutrophils reduce the parasite burden in Leishmania (Leishmania) amazonensis-infected macrophages. PloS one, v. 5, n. 11, p. e13815, 2010.

DELANEY, V. B. et al. Autosomal dominant polycystic kidney disease: presentation, complications, and prognosis. American journal of kidney diseases : the official journal of the National Kidney Foundation, v. 5, n. 2, p. 104-111, 1985.

DELGADO, O. et al. Cutaneous Leishmaniasis in Venezuela Caused by Infection with a New Hybrid between Leishmania (Viannia) braziliensis and L. (V.) guyanensis. Memórias do Instituto Oswaldo Cruz, v. 92, n. 5, p. 581-582, 1997.

DESJEUX, P. The increase in risk factors for leishmaniasis worldwide. Transactions of the Royal Society of Tropical Medicine and Hygiene, v. 95, n. 3, p. 239-243, 2001.

DESJEUX, P. Leishmaniasis: current situation and new perspectives. Comparative immunology, microbiology and infectious diseases, v. 27, n. 5, p. 305-318, 
2004.

DIAS, F. DE O. P.; LOROSA, E. S.; REBÊLO, J. M. M. Fonte alimentar sangüínea e a peridomiciliação de Lutzomyia longipalpis (Lutz \&amp; Neiva, 1912) (Psychodidae, Phlebotominae). Cadernos de Saúde Pública, v. 19, n. 5, p. 1373-1380, 2003.

DIEFENBACH, A. et al. Type 1 interferon (IFNalpha/beta) and type 2 nitric oxide synthase regulate the innate immune response to a protozoan parasite. Immunity, $v$. 8, n. 1, p. 77-87, 1998.

DIMIER-DAVID, L. et al. [A new case of autochthonous visceral leishmaniasis in Bolivia]. Annales de la Societe belge de medecine tropicale, v. 71, n. 4, p. 275278, 1991.

DOMÍNGUEZ, M. et al. Complement interaction with trypanosomatid promastigotes in normal human serum. The Journal of experimental medicine, v. 195, n. 4, p. 451-459, 2002.

DOS SANTOS, S. O. et al. Incrimination of Lutzomyia cruzi as a vector of American visceral leishmaniasis. Medical and veterinary entomology, v. 12, n. 3, p. 315-317, 1998.

DUJARDIN, J.-C. Risk factors in the spread of leishmaniases: towards integrated monitoring? Trends in parasitology, v. 22, n. 1, p. 4-6, 2006.

DUJARDIN, J. C. et al. Putative Leishmania hybrids in the Eastern Andean valley of Huanuco, Peru. Acta tropica, v. 59, n. 4, p. 293-307, 1995.

DUPREY, Z. H. et al. Canine Visceral Leishmaniasis, United States and Canada, 2000-2003. Emerging Infectious Diseases, v. 12, n. 3, p. 440-446, 2006.

EL HARITH, A. et al. Application of a direct agglutination test for detection of specific anti-Leishmania antibodies in the canine reservoir. Journal of Clinical Microbiology, v. 27, n. 10, 1989.

FERNÁNDEZ-FIGUEROA, E. A. et al. Disease severity in patients infected with Leishmania mexicana relates to IL-1 $\beta$. PLoS neglected tropical diseases, v. 6, n. 5, p. e1533, 2012.

FERREIRA, G. E. M. et al. The genetic structure of Leishmania infantum populations in Brazil and its possible association with the transmission cycle of visceral leishmaniasis. PloS one, v. 7, n. 5, p. e36242, 2012. 
FERREIRA, M. G. P. A. et al. Potential role for dog fleas in the cycle of Leishmania spp. Veterinary parasitology, v. 165, n. 1-2, p. 150-154, 2009.

FERRER, L. et al. Skin lesions in canine leishmaniasis. Journal of Small Animal Practice, v. 29, n. 6, p. 381-388, 1988.

FERRER, L. et al. Serological diagnosis and treatment of canine leishmaniasis. The Veterinary record, v. 136, n. 20, p. 514-516,1995.

FERRER, L. M. Clinical aspects of canine leishmaniasis. In: PROCEEDINGS OF THE INTERNATIONAL CANINE LEISHMANIASIS FORUM, 1999, Barcelona, Spain. Anais... Canine Leishmaniasis: an update. Hoechst Roussel Vet in Wiesbaden, 1999. p. 6-10.

FERRO, S. et al. Leishmania Amastigotes in Neoplastic Cells of 3 Nonhistiocytic Canine Tumors. Veterinary Pathology, v. 50, n. 5, p. 749-752, 2013.

FILARDY, A. A. et al. Proinflammatory clearance of apoptotic neutrophils induces an IL-12(low)IL-10(high) regulatory phenotype in macrophages. Journal of immunology (Baltimore, Md. : 1950), v. 185, n. 4, p. 2044-2050, 2010.

FISA, R. et al. Nested PCR for diagnosis of canine leishmaniosis in peripheral blood, lymph node and bone marrow aspirates. Veterinary parasitology, v. 99, n. 2, p. 105-111, 2001.

FOGLIA MANZILLO, V. et al. Prospective Study on the Incidence and Progression of Clinical Signs in Naïve Dogs Naturally Infected by Leishmania infantum. PLoS Neglected Tropical Diseases, v. 7, n. 5, p. e2225, 2013.

FORATTINI, O. P.; RABELLO, E. X.; GALATI, E. A. B. Novos encontros de flebotomíneos no Estado de São Paulo, Brasil, com especial referência à Lutzomyia longipalpis. Revista de Saúde Pública, v. 10, n. 1, p. 125-128, 1976.

FRAGA, J. et al. Phylogeny of Leishmania species based on the heat-shock protein 70 gene. Infection, genetics and evolution : journal of molecular epidemiology and evolutionary genetics in infectious diseases, v. 10, n. 2, p. 238-245, 2010.

FRANCINO, O. et al. Advantages of real-time PCR assay for diagnosis and monitoring of canine leishmaniosis. Veterinary parasitology, v. 137, n. 3-4, p. 214-221, 2006.

GALATI, E. A. B. et al. Estudo de flebotomíneos (Diptera: Psychodidae) em foco de leishmaniose visceral no Estado de Mato Grosso do Sul, Brasil. Revista de Saúde 
Pública, v. 31, n. 4, p. 378-390, 1997.

GALATI, E. A. B. Phlebotominae (Diptera, Psychodidae): classificação, morfologia, terminologia e identificação de adultos. Apostila da disciplina Bioecologia e Identificação de Phlebotominae. 2014. v.1, p. 126. São Paulo: Departamento de Epidemiologia, Faculdade de Saúde Pública, Universidade de São Paulo, 2014.

GALLETTI, E. et al. Development of a minor groove binding probe based real-time PCR for the diagnosis and quantification of Leishmania infantum in dog specimens. Research in veterinary science, v. 91, n. 2, p. 243-245, 2011.

GALVIS-OVALLOS, F. et al. Canine visceral leishmaniasis in the metropolitan area of São Paulo: Pintomyia fischeri as potential vector of Leishmania infantum. Parasite (Paris, France), v. 24, p. 2, 2017.

GIGER, U. et al. Leishmania donovani transmission by packed RBC transfusion to anemic dogs in the United States. Transfusion, v. 42, n. 3, p. 381-383, 2002.

GIUNCHETTI, R. C. et al. Relationship between canine visceral leishmaniosis and the Leishmania (Leishmania) chagasi burden in dermal inflammatory foci. Journal of comparative pathology, v. 135, n. 2-3, p. 100-107, 2006.

GOMES, Y. M. et al. Diagnosis of canine visceral leishmaniasis: Biotechnological advances. The Veterinary Journal, v. 175, n. 1, p. 45-52, 2008.

GONTIJO, C. M. F.; MELO, M. N. Leishmaniose visceral no Brasil: quadro atual, desafios e perspectivas. Revista Brasileira de Epidemiologia, v. 7, n. 3, p. 338349, 2004.

GONZÁLEZ-DE LA FUENTE, S. et al. Resequencing of the Leishmania infantum (strain JPCM5) genome and de novo assembly into 36 contigs. Scientific reports, v. 7, n. 1, p. 18050, 2017.

GRADONI, L. The diagnosis of canine leishmaniasis. In: CANINE LEISHMANIASIS: MOVING TOWARDS A SOLUTION, 2., 2002, Sevilha. Proceedings of the second international canine leishmaniasis forum. Seville: [s.n.], p. 7-14, 2002.

GRIMALDI, G.; TESH, R. B. Leishmaniases of the New World: current concepts and implications for future research. Clinical microbiology reviews, v. 6, n. 3, p. 230250, 1993. 
GUERIN, P. J. P. J. et al. Visceral leishmaniasis: current status of control, diagnosis, and treatment, and a proposed research and development agenda. The Lancet. Infectious diseases, v. 2, n. 8, p. 494-501, 2002.

GUIMARÃES-COSTA, A. B. et al. Leishmania amazonensis promastigotes induce and are killed by neutrophil extracellular traps. Proceedings of the National Academy of Sciences of the United States of America, v. 106, n. 16, p. 67486753, 2009.

GUPTA, S.; NISHI. Visceral leishmaniasis: experimental models for drug discovery. The Indian journal of medical research, v. 133, p. 27-39, 2011.

SILVA, V. G. Aspesctos entomológicos e infecção natural dos flebotomíneos por Leishmania (Leishmania) infantum chagasi em municípios do estado de São Paulo com autoctonia de transmissão de leishmaniose visceral humana e/ou canina. 135f. 2016 - DISSERTAÇÃO (Mestrado em Ciências). Coordenadoria de Controle de Doenças da Secretaria de Estado da Sáude de São Paulo. São Paulo, 2016.

HAJDUK, S.; OCHSENREITER, T. RNA editing in kinetoplastids. RNA biology, v. 7, n. 2, p. 229-236, 2010.

HALLÉ, M. et al. The Leishmania Surface Protease GP63 Cleaves Multiple Intracellular Proteins and Actively Participates in p38 Mitogen-activated Protein Kinase Inactivation. Journal of Biological Chemistry, v. 284, n. 11, p. 6893-6908, 2009.

HAMILTON, J. G. C. et al. 9-Methylgermacrene-B confirmed by synthesis as the pheromone of the sandfly Lutzomyia longipalpis from Lapinha, Brazil, and the absolute stereochemistry defined as 9S. Chemical Communications v. 8, p. 23352336, 1999.

HAMILTON, J. G. C. et al. Analysis of the sex pheromone extract of individual male Lutzomyia longipalpis sandflies from six regions in Brazil. Medical and veterinary entomology, v. 19, n. 4, p. 480-488, 2005.

HAMILTON, J. G. C. et al. ChemInform Abstract: 3-Methyl-a-himachalene is Confirmed, and the Relative Stereochemistry Defined, by Synthesis as the Sex Pheromone of the Sandfly Lutzomyia longipalpis from Jacobina, Brazil. ChemInform, v. 30, n. 26, p. 1, 2010.

HAMILTON, J. G. C.; BRAZIL, R. P.; MAINGON, R. A Fourth Chemotype of Lutzomyia longipalpis (Diptera: Psychodidae) from Jaíbas, Minas Gerais State, Brazil. Journal of Medical Entomology, v. 41, n. 6, p. 1021-1026, 2004. 
HASHIGUCHI, Y.; GÓMEZ LANDIRES, E. A. A review of leishmaniasis in Ecuador. Bulletin of the Pan American Health Organization, v. 25, n. 1, p. 64-76, 1991.

HE, D. et al. An Alternative Root for the Eukaryote Tree of Life. Current Biology, v. 24, n. 4, p. 465-470, 2014.

HERWALDT, B. L. Leishmaniasis. Lancet (London, England), v. 354, n. 9185, p. 1191-1199, 1999.

HIDE, M.; BAÑULS, A. L.; TIBAYRENC, M. Genetic heterogeneity and phylogenetic status of Leishmania (Leishmania) infantum zymodeme MON-1: epidemiological implications. Parasitology, v. 123, n. 05, p. 425-432, 2001.

HIRAMOTO, R. M. et al., 2019 Classificação epidemiológica dos municípios do Estado de São Paulo segundo o Programa de Vigilância e Controle da Leishmaniose Visceral, 2017. Boletim Epidemiológico Paulista, v. 16, n. 182, p. 11-35, 2019.

HOSEIN, S. et al. Transcription of Toll-Like Receptors 2, 3, 4 and 9, FoxP3 and Th17 Cytokines in a Susceptible Experimental Model of Canine Leishmania infantum Infection. PloS one, v. 10, n. 10, p. e0140325, 2015.

HOSEIN, S.; BLAKE, D. P.; SOLANO-GALLEGO, L. Insights on adaptive and innate immunity in canine leishmaniosis. Parasitology, v. 144, n. 01, p. 95-115, 2017.

HOTEZ, P. et al. The neglected tropical diseases: the ancient afflictions of stigma and poverty and the prospects for their control and elimination. Advances in experimental medicine and biology, v. 582, p. 23-33, 2006.

INTERNATIONAL COMMISSION ON ZOOLOGICAL NOMENCLATURE. International Code of Zoological Nomenclature. The International Trust for Zoological Nomenclature, London, 306 pp., 1999.

IVERSSON, L.B. et al. Investigação epidemiológica de um caso de Leishmaniose Visceral autóctone da grande São Paulo, Brasil. Revista de Saúde Pública, v. 13, p. 159-67, 1979.

IVERSSON, L.B. et al. Investigação epidemiológica de um novo caso de leishmaniose visceral ocorrido na Grande São Paulo, Brasil. Revista de Saúde Pública, v. 16, p. 205-219, 1982.

JUDSON, O. P.; NORMARK, B. B. Ancient asexual scandals. Trends in Ecology \& Evolution, v. 11, n. 2, p. 41-46, 1996. 
JUSI, M. M. G. et al. Molecular and serological detection of Leishmania spp. in captive wild animals from Ilha Solteira, SP, Brazil. Revista Brasileira de

Parasitologia Veterinária, v. 20, n. 3, p. 219-222, 2011.

KAMHAWI, S. Phlebotomine sand flies and Leishmania parasites: friends or foes? Trends in Parasitology, v. 22, n. 9, p. 439-445, 2006.

KAYE, P.; SCOTT, P. Leishmaniasis: complexity at the host-pathogen interface. Nature reviews. Microbiology, v. 9, n. 8, p. 604-615, 2011.

KEENAN, C. M. et al. Visceral leishmaniasis in the German shepherd dog. I. Infection, clinical disease, and clinical pathology. Veterinary pathology, v. 21, n. 1, p. 74-79, 1984a.

KEENAN, C. M. et al. Visceral leishmaniasis in the German shepherd dog. II. Pathology. Veterinary pathology, v. 21, n. 1, p. 80-86, 1984b.

KEGLER, K. et al. Vaginal canine transmissible venereal tumour associated with intra-tumoural Leishmania spp. amastigotes in an asymptomatic female dog. Journal of comparative pathology, v. 149, n. 2-3, p. 156-161, 2013.

KOUTINAS, A. F. et al. Clinical considerations on canine visceral leishmaniasis in Greece: a retrospective study of 158 cases (1989-1996). Journal of the American Animal Hospital Association, v. 35, n. 5, p. 376-383, 1999.

KOUTINAS, A. F.; KOUTINAS, C. K. Pathologic Mechanisms Underlying the Clinical Findings in Canine Leishmaniosis due to Leishmania infantum/chagasi. Veterinary Pathology, v. 51, n. 2, p. 527-538, 2014.

KRAWCZAK, F. DA S. et al. Leishmania, Babesia and Ehrlichia in urban pet dogs: co-infection or cross-reaction in serological methods? Revista da Sociedade Brasileira de Medicina Tropical, v. 48, n. 1, p. 64-68, 2015.

KUHLS, K. et al. Differentiation and gene flow among European populations of Leishmania infantum MON-1. PLoS neglected tropical diseases, v. 2, n. 7, p. e261, 2008.

LACHAUD, L. et al. Comparison of various sample preparation methods for PCR diagnosis of visceral leishmaniasis using peripheral blood. Journal of clinical microbiology, v. 39, n. 2, p. 613-617, 2001. 
Detection of Canine Visceral Leishmaniasis. Journal of Clinical Microbiology, v. 40, n. 1, p. 210-215, 2002.

LAINSON, R. The American leishmaniases: some observations on their ecology and epidemiology. Transactions of the Royal Society of Tropical Medicine and Hygiene, v. 77, n. 5, p. 569-596, 1983.

LAINSON, R. Demographic changes and their influence on the epidemiology of the American leishmaniases. In: MW Service Demography and vector-borne diseases, CRC Press, Boca Raton, p. 85-106, 1989.

LAINSON R.; SHAW J. J. Evolution, classification and geographical distribution. In: The Leishmaniasis in Biology and Medicine. Biology and Epidemiology. London: Academic Press. v. 1, p. 1-120, 1987.

LAINSON R.; RANGEL E.F. Final comments on an interesting taxonomic dilemma: Leishmania infantum versus Leishmania infantum chagasi: REPLY. Memórias do Instituto Oswaldo Cruz, v. 101, n. 8, p. 929-930, 2006.

LASKAY, T. et al. Early parasite containment is decisive for resistance to Leishmania major infection. European journal of immunology, v. 25, n. 8, p. 2220-2227, 1995.

LEITE DE SOUSA-GOMES, M. et al. Coinfecção Leishmania-HIV no Brasil: aspectos epidemiológicos, clínicos e laboratoriais. Epidemiologia e Serviços de Saúde, v. 20, n. 4, p. 519-526, 2011.

LIBERT, C. et al. LEISHMANIA INFANTUM INFECTION IN TWO CAPTIVE BARBARY LIONS ( PANTHERA LEO LEO ). Journal of Zoo and Wildlife Medicine, v. 43, n. 3, p. $685-688,2012$.

LIMA COSTA, C. R. et al. Genetic structuring and fixed polymorphisms in the gene period among natural populations of Lutzomyia longipalpis in Brazil. Parasites \& vectors, v. 8, p. 193, 2015.

LIMA, H. DE et al. Isolation and molecular identification of Leishmania chagasi from a bat (Carollia perspicillata) in northeastern Venezuela. Memórias do Instituto

Oswaldo Cruz, v. 103, n. 4, p. 412-414, 2008.

LIMA, W. G. et al. Canine visceral leishmaniasis: a histopathological study of lymph nodes. Acta Tropica, v. 92, n. 1, p. 43-53, 2004.

LIMA-JUNIOR, D. S. et al. Inflammasome-derived IL-1 $\beta$ production induces nitric 
oxide-mediated resistance to Leishmania. Nature medicine, v. 19, n. 7, p. 909-15, jul. 2013.

LINO A. M. C. D. B. et al. Leishmaniose visceral em animais domésticos no município de Cotia - São Paulo "relato de casos". In: XVIII CONGRESSO BRASILEIRO DE PARASITOLOGIA; 26-29, 2003; Rio de Janeiro, (BR). Anais... Rio de Janeiro: Associação Brasileira de Parasitologia, 2003, p. 294.

LORIA-CERVERA, E. N.; ANDRADE-NARVAEZ, F. J. ANIMAL MODELS FOR THE STUDY OF LEISHMANIASIS IMMUNOLOGY. Revista do Instituto de Medicina Tropical de São Paulo, v. 56, n. 1, p. 1-11, 2014.

LUPPI, M. M. et al. Visceral leishmaniasis in captive wild canids in Brazil. Veterinary parasitology, v. 155, n. 1-2, p. 146-151, 2008.

MAIA-ELKHOURY, A. N. S. et al. SisLeish: A multi-country standardized information system to monitor the status of Leishmaniasis in the Americas. PLOS Neglected Tropical Diseases, v. 11, n. 9, p. e0005868, 2017.

MAIA, C. et al. Diagnosis of canine leishmaniasis: conventional and molecular techniques using different tissues. Veterinary journal (London, England : 1997), v. 179, n. 1, p. 142-144, 2009.

MAIA, C.; CAMPINO, L. Cytokine and Phenotypic Cell Profiles of Leishmania infantum Infection in the Dog. Journal of tropical medicine, v. 2012, p. 541571, 2012.

MAIA, C.; NUNES, M.; CAMPINO, L. Importance of cats in zoonotic leishmaniasis in Portugal. Vector borne and zoonotic diseases (Larchmont, N.Y.), v. 8, n. 4, p. 555-559, 2008.

MALTA, M. C. C. et al. Naturally acquired visceral leishmaniasis in non-human primates in Brazil. Veterinary parasitology, v. 169, n. 1-2, p. 193-197, 2010.

MANCIANTI, F. et al. Studies on canine leishmaniasis control. 1. Evolution of infection of different clinical forms of canine leishmaniasis following antimonial treatment. Transactions of the Royal Society of Tropical Medicine and Hygiene, v. 82 , n. 4 , p. 566-567, 1988.

MANCIANTI, F. et al. Comparison between an enzyme-linked immunosorbent assay using a detergent-soluble Leishmania infantum antigen and indirect immunofluorescence for the diagnosis of canine leishmaniosis. Veterinary parasitology, v. 59, n. 1, p. 13-21, 1995. 
MANNA, L. et al. Comparison of different tissue sampling for PCR-based diagnosis and follow-up of canine visceral leishmaniosis. Veterinary parasitology, v. 125, n. 3-4, p. 251-262, 2004.

MÁRQUEZ, M. et al. Leishmania amastigotes in the central nervous system of a naturally infected dog. Journal of veterinary diagnostic investigation : official publication of the American Association of Veterinary Laboratory Diagnosticians, Inc, v. 25, n. 1, p. 142-146, 2013.

MARTÍN-MARTÍN, I. et al. Natural transmission of Leishmania infantum through experimentally infected Phlebotomus perniciosus highlights the virulence of Leishmania parasites circulating in the human visceral leishmaniasis outbreak in Madrid, Spain. Veterinary research, v. 46, p. 138, 2015.

MARTIIN-SÁNCHEZ, J. et al. Infection by Leishmania infantum in cats: epidemiological study in Spain. Veterinary parasitology, v. 145, n. 3-4, p. 267-273, 2007.

MARTÍNEZ-MORENO, A. et al. Immunological and histological study of T- and Blymphocyte activity in canine visceral leishmaniosis. Veterinary parasitology, v. 51, n. 1-2, p. 49-59, 1993.

MARZOCHI, M. C. DE A.; MARZOCHI, K. B. F. Tegumentary and visceral leishmaniases in Brazil: emerging anthropozoonosis and possibilities for their control. Cadernos de Saúde Pública, v. 10, n. suppl 2, p. S359-S375, 1994.

MATHIS, A.; DEPLAZES, P. PCR and in vitro cultivation for detection of Leishmania spp. in diagnostic samples from humans and dogs. Journal of clinical microbiology, v. 33, n. 5, p. 1145-1149, 1995.

MAURICIO, I. L. et al. Genetic typing and phylogeny of the Leishmania donovani complex by restriction analysis of PCR amplified gp63 intergenic regions.

Parasitology, v. 122, n. Pt 4, p. 393-403, 2001.

MEKUZAS, Y. et al. Ehrlichia canis and Leishmania infantum co-infection: a 3-year longitudinal study in naturally exposed dogs. Clinical Microbiology and Infection, v. 15, p. 30-31, 2009.

MELÉNDEZ-LAZO, A. et al. Clinicopathological findings in sick dogs naturally infected with Leishmania infantum : Comparison of five different clinical classification systems. Research in Veterinary Science, v. 117, p. 18-27, abr. 2018.

MENON, S. S. et al. Decentralized control of human visceral leishmaniasis in 
endemic urban areas of Brazil: a literature review. Tropical Medicine and Health, $v$. 44, n. 1, p. 9, 2016.

MESTRE, G. L. DA C.; FONTES, C. J. F. A expansão da epidemia da leishmaniose visceral no Estado de Mato Grosso, 1998-2005. Revista da Sociedade Brasileira de Medicina Tropical, v. 40, n. 1, p. 42-48, 2007.

MIGONE, L. E. Un caso de Kalazar en Assunción (Paraguay). Bulletin Societe Pathologic Exotique, v. 6, p.118-120, 1913.

MILES, M. A. et al. The molecular epidemiology and phylogeography of Trypanosoma cruzi and parallel research on Leishmania: looking back and to the future. Parasitology, v. 136, n. 12, p. 1509-1528, 2009.

MILLÁN, J. et al. Detection of Leishmania DNA in wild foxes and associated ticks in Patagonia, Argentina, $2000 \mathrm{~km}$ south of its known distribution area. Parasites \& Vectors, v. 9, n. 1, p. 241, 2016.

MILLÁN, J.; FERROGLIO, E.; SOLANO-GALLEGO, L. Role of wildlife in the epidemiology of Leishmania infantum infection in Europe. Parasitology research, $v$. 113, n. 6, p. 2005-2014, 2014.

MILES, M. A. et al. Canine Leishmaniasis in Latin America: control strategies for visceral leishmaniasis. In: PROCEEDINGS OF THE INTERNATIONAL CANINE LEISHMANIASIS FORUM, 46-53, 1999 Barcelona. Anais... Hoechst Roussel Vet in Wiesbaden, Wiesbaden, p. 46-53, 1999.

MIRÓ, G. et al. Canine leishmaniosis--new concepts and insights on an expanding zoonosis: part two. Trends in parasitology, v. 24, n. 8, p. 371-377, 2008.

MISSAWA, N. A. et al. Evidência de transmissão de leishmaniose visceral por Lutzomyia cruzi no município de Jaciara, Estado de Mato Grosso, Brasil. Revista da Sociedade Brasileira de Medicina Tropical, v. 44, n. 1, p. 76-78, 2011.

MOLINA, R. et al. The hare (Lepus granatensis) as potential sylvatic reservoir of Leishmania infantum in Spain. Veterinary parasitology, v. 190, n. 1-2, p. 268-271, 2012.

MOLLINEDO, F. et al. Selective fusion of azurophilic granules with Leishmaniacontaining phagosomes in human neutrophils. The Journal of biological chemistry, v. 285, n. 45, p. 34528-34536, 2010. 
MORAES, C. S. et al. Second Blood Meal by Female Lutzomyia longipalpis :

Enhancement by Oviposition and Its Effects on Digestion, Longevity, and Leishmania Infection. BioMed Research International, v. 2018, p. 1-10, 2018.

MORALES, M. A. et al. Molecular tracking of infections by Leishmania infantum.

Transactions of the Royal Society of Tropical Medicine and Hygiene, v. 95, n. 1, p. 104-107, 2001.

MOREHEAD, J.; COPPENS, I.; ANDREWS, N. W. Opsonization Modulates Rac-1 Activation during Cell Entry by Leishmania amazonensis. Infection and Immunity, v. 70, n. 8, p. 4571-4580, 2002.

MORENO, J.; ALVAR, J. Canine leishmaniasis: epidemiological risk and the experimental model. Trends in parasitology, v. 18, n. 9, p. 399-405, 2002.

MOTOIE, G. et al. Spatial distribution and population genetics of Leishmania infantum genotypes in São Paulo State, Brazil, employing multilocus microsatellite typing directly in dog infected tissues. Infection, genetics and evolution : journal of molecular epidemiology and evolutionary genetics in infectious diseases, v. 18, p. 48-59, 2013.

MOYA, S. L. et al. First description of Migonemyia migonei (França) and Nyssomyia whitmani (Antunes \& Coutinho) (Psychodidae: Phlebotominae) natural infected by Leishmania infantum in Argentina. Acta tropica, v. 152, p. 181-184, 2015.

MÜLLER, K. et al. Chemokines, natural killer cells and granulocytes in the early course of Leishmania major infection in mice. Medical microbiology and immunology, v. 190, n. 1-2, p. 73-76, 2001.

MYLONAKIS, M. E. et al. Cytologic patterns of lymphadenopathy in dogs infected with Leishmania infantum. Veterinary Clinical Pathology, v. 34, n. 3, p. 243-247, 2005.

NAVIN, T. R. et al. Epidemiologic study of visceral leishmaniasis in Honduras, 19751983. The American Journal of Tropical Medicine and Hygiene, v. 34, p. 1069-75, 1985.

NICOLLE C., COMTE C. Origine du Kala azar. Academy of Science, v. 146, p. 789, 1908.

NIETO, C. G. et al. Pathological changes in kidneys of dogs with natural Leishmania infection. Veterinary parasitology, v. 45, n. 1-2, p. 33-47, 1992. 
NOLDER, D. et al. Multiple hybrid genotypes of Leishmania (viannia) in a focus of mucocutaneous Leishmaniasis. The American journal of tropical medicine and hygiene, v. 76, n. 3, p. 573-578, 2007.

NOVAIS, F. O. et al. Neutrophils and macrophages cooperate in host resistance against Leishmania braziliensis infection. Journal of immunology (Baltimore, Md. : 1950), v. 183, n. 12, p. 8088-8098, 2009.

OCHSENREITHER, S. et al. Multilocus Microsatellite Typing as a New Tool for Discrimination of Leishmania infantum MON-1 Strains. Journal of Clinical Microbiology, v. 44, n. 2, p. 495-503, 2006.

OLIVEIRA, A. M. et al. Dispersion of Lutzomyia longipalpis and expansion of visceral leishmaniasis in São Paulo State, Brazil: identification of associated factors through survival analysis. Parasites \& Vectors, v. 11, n. 1, p. 503, 2018.

OLIVEIRA, R. P. et al. An alternative approach to evaluating the intraspecific genetic variability of parasites. Parasitology today (Personal ed.), v. 13, n. 5, p. 196-200, 1997.

ORDEIX, L. et al. Papular dermatitis due to Leishmania spp. infection in dogs with parasite-specific cellular immune responses. Veterinary dermatology, v. 16, n. 3, p. 187-191, 2005.

OSORIO, G. et al. [Visceral leishmaniasis (kala-azar): 1st case observed in Chile]. Revista medica de Chile, v. 112, n. 3, p. 261-266, 1984.

OWENS, S. D. et al. Transmission of visceral leishmaniasis through blood transfusions from infected English Foxhounds to anemic dogs. Journal of the American Veterinary Medical Association, v. 219, n. 8, p. 1076-1083, 2001.

PAHO, PAN AMERICAN HEALTH ORGANIZATION. Leishmaniasis:

Epidemiological Report in the Americas. Washington: Pan American Health Organization; 2018. Disponível em: <www.paho.org/leishmaniasis> Acesso em: 18.11.2018.

PALATNIK-DE-SOUSA, C. B. C. B. et al. Improving methods for epidemiological control of canine visceral leishmaniasis based on a mathematical model. Impact on the incidence of the canine and human disease. Anais da Academia Brasileira de Ciencias, v. 76, n. 3, p. 583-593, 2004.

PALTRINIERI, S. et al. Guidelines for diagnosis and clinical classification of leishmaniasis in dogs. Journal of the American Veterinary Medical Association, 
v. 236, n. 11, p. 1184-1191, 2010.

PANGRAZIO, K. K. et al. Tissue distribution of Leishmania chagasi and lesions in transplacentally infected fetuses from symptomatic and asymptomatic naturally infected bitches. Veterinary parasitology, v. 165, n. 3-4, p. 327-331, 2009.

PAPADOGIANNAKIS, E. et al. Molecular detection of Leishmania infantum in wild rodents (Rattus norvegicus) in Greece. Zoonoses and public health, v. 57, n. 7-8, p. e23-5, 2010.

PATIL, T. et al. Pro-inflammatory cytokine Interleukin-1 1 (IL-1 $\beta$ ) controls Leishmania infection. Cytokine, v. 112, p. 27-31, dez. 2018.

PEACOCK, C. S. et al. Comparative genomic analysis of three Leishmania species that cause diverse human disease. Nature genetics, v. 39, n. 7, p. 839-847, 2007.

PEARSON, R. D.; SOUSA, A. Q. Clinical spectrum of Leishmaniasis. Clinical infectious diseases : an official publication of the Infectious Diseases Society of America, v. 22, n. 1, p. 1-13, 1996.

PEARSON, R. D.; STEIGBIGEL, R. T. Phagocytosis and killing of the protozoan Leishmania donovani by human polymorphonuclear leukocytes. Journal of immunology (Baltimore, Md. : 1950), v. 127, n. 4, p. 1438-1443, 1981.

PENNA, H. A. Leishmaniose Visceral no Brasil. Brasil Médico, v. 18, p. 940-950, 1934.

PENNISI, M.-G. et al. LeishVet update and recommendations on feline leishmaniosis. Parasites \& Vectors, v. 8, n. 1, p. 302, 2015.

PETERSEN, C. A.; BARR, S. C. Canine Leishmaniasis in North America: Emerging or Newly Recognized? Veterinary Clinics of North America: Small Animal Practice, v. 39, n. 6, p. 1065-1074, 2009.

PINELLI, E. et al. Cellular and humoral immune responses in dogs experimentally and naturally infected with Leishmania infantum. Infection and immunity, v. 62, n. 1, p. 229-235, 1994.

PINELLI, E. et al. Infection of a canine macrophage cell line with leishmania infantum: determination of nitric oxide production and anti-leishmanial activity.

Veterinary parasitology, v. 92, n. 3, p. 181-189, 2000. 
PODALIRI VULPIANI, M. et al. Methods of Control of the Leishmania infantum Dog Reservoir: State of the Art. Veterinary Medicine International, v. 2011, p. 1-13, 2011.

POMPEU, M. L. et al. Granulocytes in the inflammatory process of BALB/c mice infected by Leishmania amazonensis. A quantitative approach. Acta tropica, v. 48, n. 3, p. 185-193, 1991.

PRAJEETH, C. K. et al. Leishmania-infected macrophages are targets of NK cellderived cytokines but not of NK cell cytotoxicity. Infection and immunity, v. 79, n. 7, p. 2699-2708, 2011.

QUINNELL, R. J. et al. Detection of Leishmania infantum by PCR, serology and cellular immune response in a cohort study of Brazilian dogs. Parasitology, v. 122, n. Pt 3, p. 253-261, 2001.

QUINNELL, R. J. et al. Susceptibility to visceral leishmaniasis in the domestic dog is associated with MHC class II polymorphism. Immunogenetics, v. 55, n. 1, p. 23-28, 2003.

QUISPE TINTAYA, K. W. et al. Antigen genes for molecular epidemiology of leishmaniasis: polymorphism of cysteine proteinase $B$ and surface metalloprotease glycoprotein 63 in the Leishmania donovani complex. The Journal of infectious diseases, v. 189, n. 6, p. 1035-1043, 2004.

RACHAMIM, N. et al. Serodiagnosis of canine visceral leishmaniasis in Portugal: comparison of three methods. Annals of tropical medicine and parasitology, $v$. 85, n. 5, p. 503-508, 1991.

RANGEL, O. et al. Classificação epidemiológica dos municípios segundo o Programa de Vigilância e Controle da Leishmaniose Visceral Americana no estado de São Paulo, para 2013. Boletim Epidemiológico Paulista, v. 10, n. 111, p. 3-14, 2013.

RANGEL, O. et al. Leishmaniose visceral no estado de São Paulo: tendência geral da letalidade entre 1999 a 2013 e o risco de óbitos por estratificação epidemiológica dos municípios e regionais de vigilância epidemiológica entre 2011 a 2013. Boletim Epidemiológico Paulista, v. 12, n. 143, p. 1-8, 2015.

READY, P. Epidemiology of visceral leishmaniasis. Clinical Epidemiology, p. 147, 2014.

REALE, S. et al. Detection of Leishmania infantum in dogs by PCR with lymph node aspirates and blood. Journal of clinical microbiology, v. 37, n. 9, p. 2931-2935, 
1999.

REIS, A. B. et al. Isotype patterns of immunoglobulins: hallmarks for clinical status and tissue parasite density in Brazilian dogs naturally infected by Leishmania (Leishmania) chagasi. Veterinary immunology and immunopathology, v. 112, n. 3-4, p. 102-116, 2006a.

REIS, A. B. et al. Phenotypic features of circulating leucocytes as immunological markers for clinical status and bone marrow parasite density in dogs naturally infected by Leishmania chagasi. Clinical and experimental immunology, v. 146, n. 2, p. 303, 2006b.

REIS, A. B. et al. Systemic and compartmentalized immune response in canine visceral leishmaniasis. Veterinary immunology and immunopathology, v. 128, n. 1-3, p. 87-95, 2009.

REITHINGER, R.; DUJARDIN, J.-C. Molecular Diagnosis of Leishmaniasis: Current Status and Future Applications. Journal of Clinical Microbiology, v. 45, n. 1, p. $21-$ 25, 2007.

REY, L. Bases da parasitologia médica. Rio de Janeiro: Guanabara Koogan; 2010. $404 \mathrm{p}$.

REZAI, H. R.; SHER, S.; GETTNER, S. Leishmania tropica, L. donovani, and L. enriettii: immune rabbit serum inhibitory in vitro. Experimental parasitology, v. 26, n. 3, p. 257-263, 1969.

REZVAN, H.; MOAFI, M. An overview on Leishmania vaccines: A narrative review article. Veterinary research forum : an international quarterly journal, v. $6, n$. 1, p. 1-7, 2015.

RIBEIRO-GOMES, F. L. et al. Macrophage interactions with neutrophils regulate Leishmania major infection. Journal of immunology (Baltimore, Md. : 1950), v. 172, n. 7, p. 4454-4462, 2004.

RIBEIRO-GOMES, F. L.; SACKS, D. The influence of early neutrophil-Leishmania interactions on the host immune response to infection. Frontiers in Cellular and Infection Microbiology, v. 2, 2012.

RIBOLLA, P. E. M. et al. Leishmania infantum Genetic Diversity and Lutzomyia longipalpis Mitochondrial Haplotypes in Brazil. BioMed Research International, v. 2016, p. 1-11, 2016. 
RICHINI-PEREIRA, V. et al. Molecular detection of Leishmania spp. in road-killed wild mammals in the Central Western area of the State of São Paulo, Brazil. Journal of Venomous Animals and Toxins including Tropical Diseases, v. 20, n. 1, p. 27, 2014.

RIGO, R. S. et al. Renal histopathological findings in dogs with visceral leishmaniasis. Revista do Instituto de Medicina Tropical de Sao Paulo, v. 55, n. 2, p. 113-116, 2013.

RIOUX, J. A. et al. Taxonomy of Leishmania. Use of isoenzymes. Suggestions for a new classification. Annales de parasitologie humaine et comparee, v. 65, n. 3, p. 111-125, 1990.

ROCHETTE, A. et al. Genome-wide gene expression profiling analysis of Leishmania major and Leishmania infantum developmental stages reveals substantial differences between the two species. BMC genomics, v. 9, p. 255, 2008.

RODRÍGUEZ-CORTÉS, A. et al. Leishmania-specific isotype levels and their relationship with specific cell-mediated immunity parameters in canine leishmaniasis. Veterinary immunology and immunopathology, v. 116, n. 3-4, p. 190-198, 2007.

ROGERS, K.S.; BARTON, C.L.; LANDIS, M. Canine and feline lymph nodes. Part II. Diagnosis, evaluation and lymphadenopathy. The Compendium on Continuing Education for the Practicing Veterinarian, v. 15, p. 1493-1501, 1993.

ROGERS, M. B. et al. Chromosome and gene copy number variation allow major structural change between species and strains of Leishmania. Genome research, v. 21, n. 12, p. 2129-2142, 2011.

ROGERS, M. E.; CHANCE, M. L.; BATES, P. A. The role of promastigote secretory $\mathrm{gel}$ in the origin and transmission of the infective stage of Leishmania mexicana by the sandfly Lutzomyia longipalpis. Parasitology, v. 124, n. Pt 5, p. 495-507, 2002.

ROLÃO, N. et al. Equine infection with Leishmania in Portugal. Parasite (Paris, France), v. 12, n. 2, p. 183-186, 2005.

ROSA, F. A. et al. Cardiac lesions in 30 dogs naturally infected with Leishmania infantum chagasi. Veterinary pathology, v. 51, n. 3, p. 603-606, 2014.

ROSSI, M.; FASEL, N. The criminal association of Leishmania parasites and viruses. Current Opinion in Microbiology, v. 46, p. 65-72, 2018. 
ROSYPAL, A. C. et al. Transplacental transmission of a North American isolate of Leishmania infantum in an experimentally infected beagle. The Journal of parasitology, v. 91, n. 4, p. 970-972, 2005.

ROTUREAU, B. et al. First report of Leishmania infantum in French Guiana: canine visceral leishmaniasis imported from the Old World. Journal of clinical

microbiology, v. 44, n. 3, p. 1120-1122, 2006.

ROUGERON, V. et al. "Everything You Always Wanted to Know about Sex (but Were Afraid to Ask)" in Leishmania after Two Decades of Laboratory and Field Analyses. PLoS Pathogens, v. 6, n. 8, p. e1001004, 2010.

ROURA, X. et al. Prognosis and monitoring of leishmaniasis in dogs: A working group report. The Veterinary Journal, v. 198, n. 1, p. 43-47, 2013.

SÁDLOVÁ, J.; VOLF, P. Peritrophic matrix of Phlebotomus duboscqi and its kinetics during Leishmania major development. Cell and Tissue Research, v. 337, n. 2, p. 313-325, 2009.

SALOMÓN, O. D. et al. Lutzomyia migonei as putative vector of visceral leishmaniasis in La Banda, Argentina. Acta Tropica, v. 113, n. 1, p. 84-87, 2010.

SANTIAGO, M. E. B. et al. An investigation of Leishmania spp. in Didelphis spp. from urban and peri-urban areas in Bauru (São Paulo, Brazil). Veterinary Parasitology, v. 150, n. 4 , p. $283-290,2007$.

SARIDOMICHELAKIS, M. N. Advances in the pathogenesis of canine leishmaniosis: epidemiologic and diagnostic implications. Veterinary dermatology, v. 20, n. 5-6, p. 471-489, 2009.

SARIDOMICHELAKIS, M. N.; KOUTINAS, A. F. Cutaneous involvement in canine leishmaniosis due to $L$ eishmania infantum (syn. L. chagasi ). Veterinary Dermatology, v. 25, n. 2, p. 61-e22, 2014.

SAVANI, E. S. M. M. et al. The finding of Lutzomyia almerioi and Lutzomyia longipalpis naturally infected by Leishmania spp. in a cutaneous and canine visceral leishmaniases focus in Serra da Bodoquena, Brazil. Veterinary Parasitology, v. 160, n. 1-2, 2009.

SCHARTON, T. M.; SCOTT, P. Natural killer cells are a source of interferon gamma that drives differentiation of CD4+ T cell subsets and induces early resistance to Leishmania major in mice. The Journal of experimental medicine, v. 178, n. 2, p. 567-577, 1993. 
SCHULZ, A. et al. Detection, Differentiation, and Quantitation of Pathogenic Leishmania Organisms by a Fluorescence Resonance Energy Transfer-Based RealTime PCR Assay. Journal of Clinical Microbiology, v. 41, n. 4, p. 1529-1535, 2003.

SCOTCH, M.; ODOFIN, L.; RABINOWITZ, P. Linkages between animal and human health sentinel data. BMC Veterinary Research, v. 5, n. 1, p. 15, 2009.

SEBLOVA, V. et al. Natural hybrid of Leishmania infantum/L. donovani: development in Phlebotomus tobbi, P. perniciosus and Lutzomyia longipalpis and comparison with non-hybrid strains differing in tissue tropism. Parasites \& vectors, v. 8, p. 605, 2015.

SEGATTO, M. et al. Genetic diversity of Leishmania infantum field populations from Brazil. Memorias do Instituto Oswaldo Cruz, v. 107, n. 1, p. 39-47, 2012.

SELLS, P. G.; BURTON, M. Identification of Leishmania amastigotes and their antigens in formalin fixed tissue by immunoperoxidase staining. Transactions of the Royal Society of Tropical Medicine and Hygiene, v. 75, n. 3, p. 461-468, 1981.

SHAW, J. J. Further thoughts on the use of the name Leishmania (Leishmania) infantum chagasi for the aetiological agent of American visceral leishmaniasis. Memorias do Instituto Oswaldo Cruz, v. 101, n. 5, p. 577-579, 2006.

SHAW, S. E.; LANGTON, D. A.; HILLMAN, T. J. Canine leishmaniosis in the United Kingdom: a zoonotic disease waiting for a vector? Veterinary parasitology, v. 163, n. 4, p. 281-285, 2009.

SHIMOZAKO, H. J.; WU, J.; MASSAD, E. The Preventive Control of Zoonotic Visceral Leishmaniasis: Efficacy and Economic Evaluation. Computational and Mathematical Methods in Medicine, v. 2017, p. 1-21, 2017.

SILVA, A. R. et al. Leishmaniose visceral (calazar) na llha de São Luís, Maranhão, Brasil: evolução e perspectivas. Revista da Sociedade Brasileira de Medicina Tropical, v. 30, p. 359-368, 1997.

SILVA, F. L. et al. Venereal transmission of canine visceral leishmaniasis. Veterinary parasitology, v. 160, n. 1-2, p. 55-59, 2009.

SLAPPENDEL, R. J. Canine leishmaniasis. A review based on 95 cases in The Netherlands. The Veterinary quarterly, v. 10, n. 1, p. 1-16, 1988.

SOARES, R. P. P.; TURCO, S. J. Lutzomyia longipalpis (Diptera: Psychodidae: Phlebotominae): a review. Anais da Academia Brasileira de Ciências, v. 75, n. 3, 
p. 301-330, 2003.

SOLANO-GALLEGO, L. et al. Prevalence of Leishmania infantum infection in dogs living in an area of canine leishmaniasis endemicity using PCR on several tissues and serology. Journal of clinical microbiology, v. 39, n. 2, p. 560-563, 2001.

SOLANO-GALLEGO, L. et al. Directions for the diagnosis, clinical staging, treatment and prevention of canine leishmaniosis. Veterinary Parasitology, v. 165, n. 1-2, p. 1-18, 2009.

SOLANO-GALLEGO, L. et al. LeishVet guidelines for the practical management of canine leishmaniosis. Parasites \& vectors, v. 4, p. 86, 2011.

SOLANO-GALLEGO, L. et al. Detection of Leishmania infantum DNA mainly in Rhipicephalus sanguineus male ticks removed from dogs living in endemic areas of canine leishmaniosis. Parasites \& Vectors, v. 5, n. 1, p. 98, 2012.

SOLCÀ, M. DA S. et al. Evaluating the Accuracy of Molecular Diagnostic Testing for Canine Visceral Leishmaniasis Using Latent Class Analysis. PLoS ONE, v. 9, n. 7, p. e103635, 2014.

SOUZA, T. D. T. D. et al. Visceral leishmaniasis in zoo and wildlife. Veterinary parasitology, v. 200, n. 3-4, p. 233-241, 2014.

STRAUSS-AYALI, D.; BANETH, G.; JAFFE, C. L. Splenic immune responses during canine visceral leishmaniasis. Veterinary research, v. 38, n. 4, p. 547-564, 2007.

SUNDAR, S.; RAI, M. Laboratory diagnosis of visceral leishmaniasis. Clinical and diagnostic laboratory immunology, v. 9, n. 5, p. 951-958, 2002.

TABAR, M. D. et al. Detection of Leishmania infantum by real-time PCR in a canine blood bank. Journal of Small Animal Practice, v. 49, n. 7, p. 325-328, 2008.

TABAR, M. D. et al. Wolbachia, filariae and Leishmania coinfection in dogs from a Mediterranean area. Journal of Small Animal Practice, v. 54, n. 4, p. 174-178, 2013.

TAFURI, W. L. et al. Canine visceral leishmaniosis: a remarkable histopathological picture of one case reported from Brazil. Veterinary parasitology, v. 96, n. 3, p. 203-212, 2001.

TAUIL, P. L. Perspectivas de controle de doenças transmitidas por vetores no Brasil. 
Revista da Sociedade Brasileira de Medicina Tropical, v. 39, n. 3, p. 275-277, 2006.

TAVARES VERAS, P. S. et al. New Advances in the Diagnosis of Canine Visceral Leishmaniasis. In: Leishmaniasis - Trends in Epidemiology, Diagnosis and Treatment. [s.I.] InTech, 2014.

TESH, R. B. Control of zoonotic visceral leishmaniasis: is it time to change strategies? The American journal of tropical medicine and hygiene, v. 52, n. 3, p. 287-292, 1995.

THALHOFER, C. J. et al. Leukocytes infiltrate the skin and draining lymph nodes in response to the protozoan Leishmania infantum chagasi. Infection and immunity, v. 79, n. 1, p. 108-117, 2011.

TIBAYRENC, M.; AYALA, F. J. Towards a population genetics of microorganisms: The clonal theory of parasitic protozoa. Parasitology today (Personal ed.), v. 7, $\mathrm{n}$. 9, p. 228-232, 1991.

TIBAYRENC, M.; AYALA, F. J. How clonal are Trypanosoma and Leishmania? Trends in parasitology, v. 29, n. 6, p. 264-269, 2013.

TIBAYRENC, M.; KJELLBERG, F.; AYALA, F. J. A clonal theory of parasitic protozoa: the population structures of Entamoeba, Giardia, Leishmania, Naegleria, Plasmodium, Trichomonas, and Trypanosoma and their medical and taxonomical consequences. Proceedings of the National Academy of Sciences of the United States of America, v. 87, n. 7, p. 2414-2418, 1990.

TOLEZANO, J. E. et al. Leishmaniose Visceral Americana (LVA) em Araçatuba, região oeste do Estado de São Paulo. Investigações laboratoriais e diagnóstico de uma doença emergente em terras paulistas. Revista da Sociedade Brasileira de Medicina Tropical, v. 32, n. 2, p. 218, 1999.

TREJO-PÉREZ, J. A. et al. [Kala-azar in Mexico: report of 2 cases]. Boletin medico del Hospital Infantil de Mexico, v. 50, n. 9, p. 662-665, 1993.

TRYPHONAS, L. et al. Visceral leishmaniasis in a dog: clinical, hematological and pathological observations. Canadian journal of comparative medicine : Revue canadienne de medecine comparee, v. 41, n. 1, p. 1-12, 1977.

VAMVAKIDIS, C. D. et al. Masticatory and skeletal muscle myositis in canine leishmaniasis (Leishmania infantum). The Veterinary record, v. 146, n. 24, p. 698703, 2000. 
VERCAMMEN, F. et al. Development of a slide ELISA for canine leishmaniasis and comparison with four serological tests. Veterinary Record, v. 141, n. 13, p. 328-330, 1997.

VOLF, P. et al. Increased transmission potential of Leishmania major/Leishmania infantum hybrids. International journal for parasitology, v. 37, n. 6, p. 589-593, 2007.

WARBURG, A. et al. Scanning electron microscopy of Leishmania major in Phlebotomus papatasi. Zeitschrift fur Parasitenkunde (Berlin, Germany), v. 72, n. 4, p. 423-431, 1986.

WARD R. D., BURNET, P. A., MARCONDES, C. B. The Lutzomyia longipalpis complex: reproduction and distribution, 258-269, 1988. In: Service M. W. [ed.], Biosystematics of haematophagous insects. Oxford University Press, Oxford, United Kingdom, p. 258-269, 1988.

WARD, R. D. et al. Reproductive isolation between different forms of Lutzomyia longipalpis (Lutz; Neiva), (Diptera: Psychodidae), the vector of Leishmania donovani chagasi Cunha; Chagas and its significance to kala-azar distribution in South America. Memórias do Instituto Oswaldo Cruz, v. 78, n. 3, p. 269-280, 1983.

WARD, R. D.; MORTON, I. E. Pheromones in mate choice and sexual isolation between siblings of Lutzomyia longipalpis (Diptera:Psychodidae). Parassitologia, v. 33 Suppl, p. 527-533, 1991.

WERNECK, G. L. et al. The burden of Leishmania chagasi infection during an urban outbreak of visceral leishmaniasis in Brazil. Acta tropica, v. 83, n. 1, p. 13-18, 2002.

WINCKER, P. et al. The Leishmania genome comprises 36 chromosomes conserved across widely divergent human pathogenic species. Nucleic acids research, v. 24, n. 9, p. 1688-1694, 1996.

WORLD HEALTH ORGANIZATION. Control of the leishmaniases. World Health Organization technical report series, n. 949, p. xii-xiii, 1-186, back cover, 2010.

ZATELLI, A. et al. Glomerular lesions in dogs infected with Leishmania organisms. American journal of veterinary research, v. 64, n. 5, p. 558-561, 2003.

ZEMANOVÁ, E. et al. Genetic polymorphism within the leishmania donovani complex: correlation with geographic origin. The American journal of tropical medicine and hygiene, v. 70, n. 6, p. 613-617, 2004. 
ZERPA, O. et al. Epidemiological aspects of human and canine visceral leishmaniasis in Venezuela. Revista panamericana de salud publica $=\mathbf{P a n}$ American journal of public health, v. 13, n. 4, p. 239-245, 2003. 